
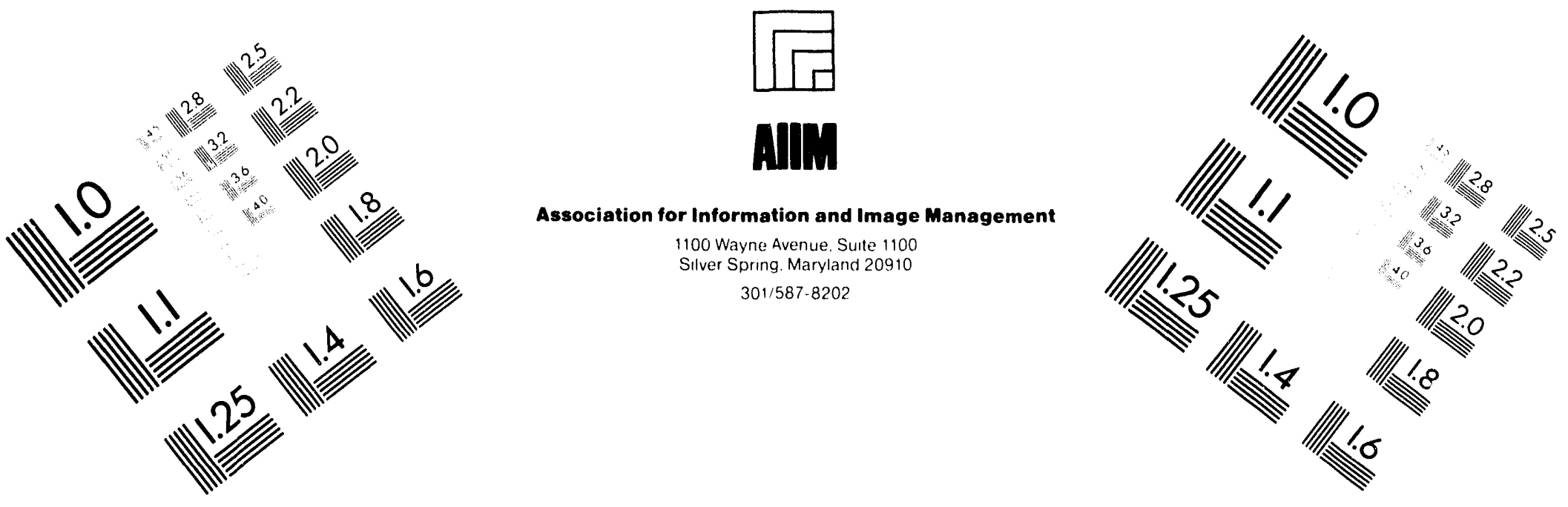

\title{
Centimeter
}

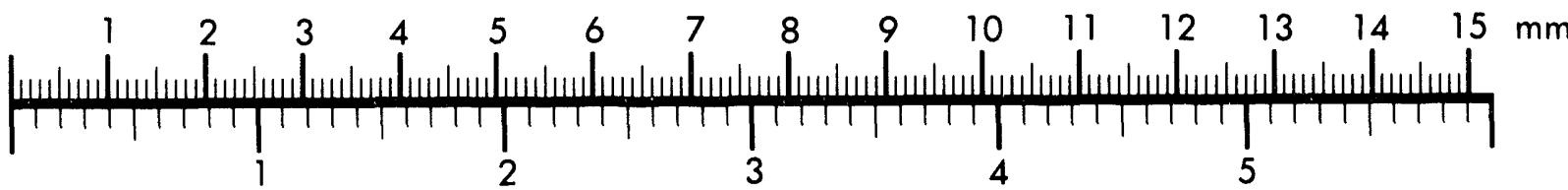
Inches
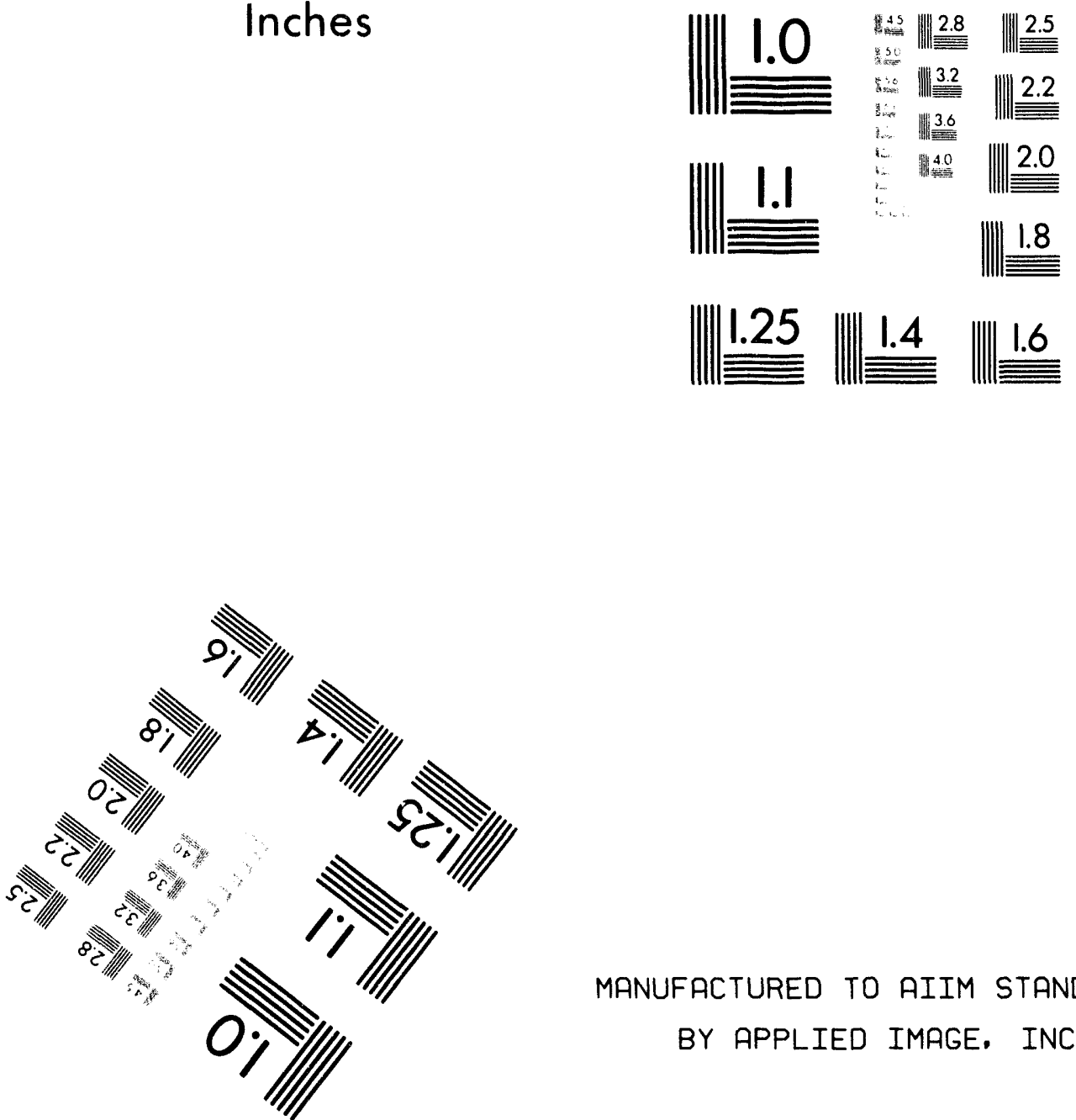

MANUFACTURED TO AIIM STANDARDS

BY APPLIED IMAGE, INC.

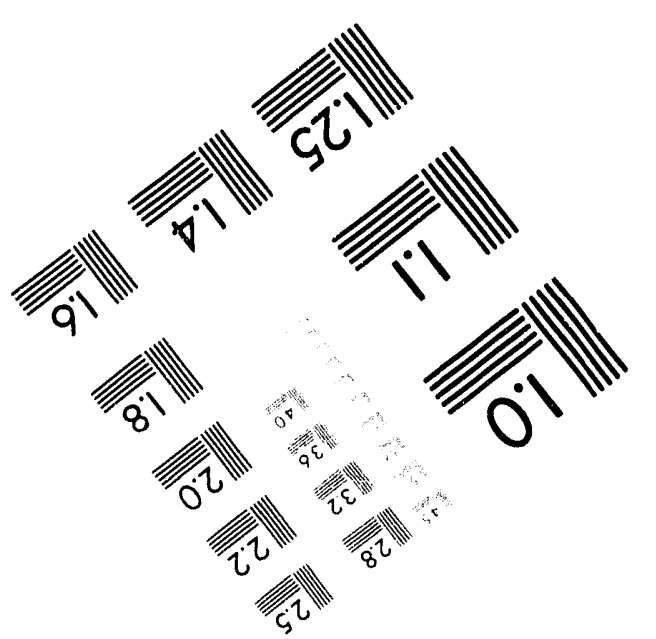



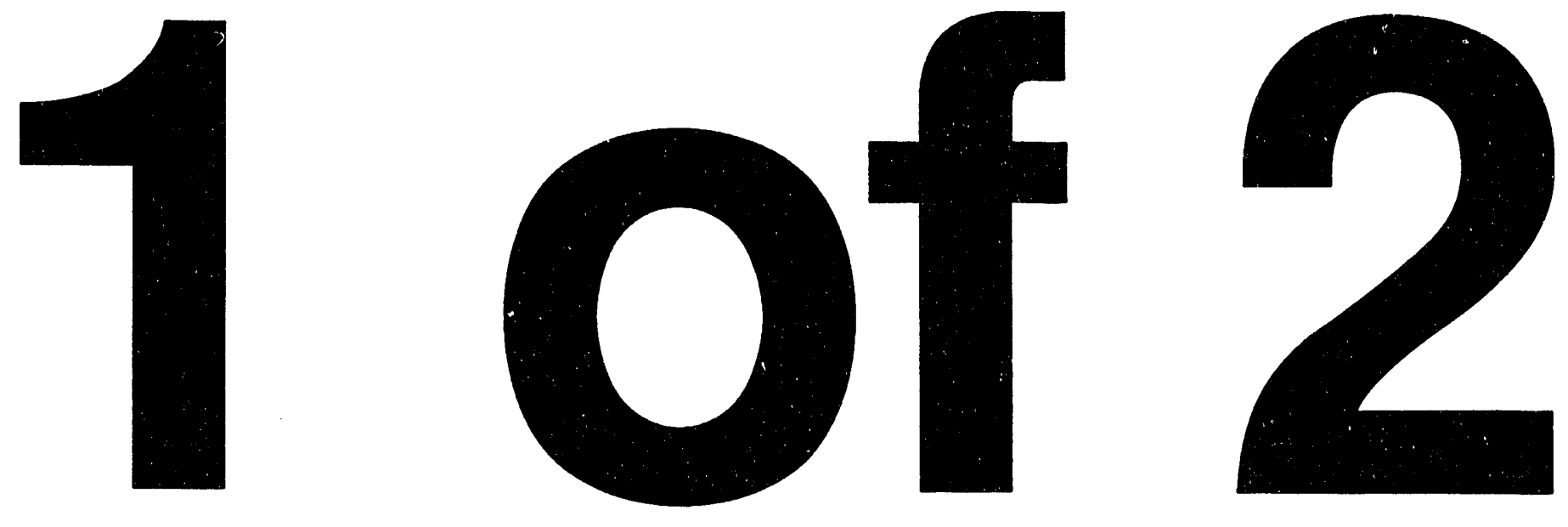


\section{SPENT FUEL AND WASTE MANAGEMENT TECHNOLOGY DEVELOPMENT PROGRAM ANNUAL PROGRESS REPORT}

I W. Bryant

January 1994

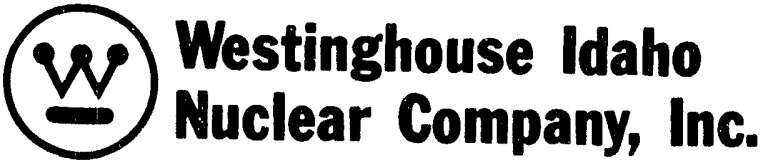

PREPARED FOR THE DEPARTMENT OF ENERGY IDAHO OPERATIONS OFFICE UNDER CONTRACT DE-AC07-84ID12435

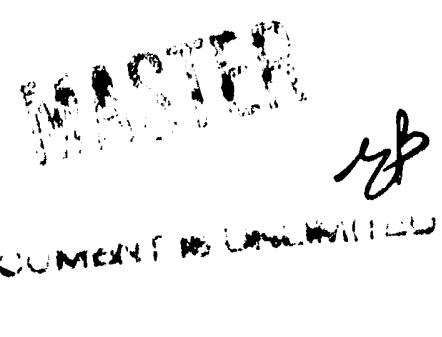


This report provides information on the progress of activities during fiscal year 1993 in the Spent Fuel and Waste Management Technology Development Program (SF\&WMTDP) at the Idaho Chemical Processing Plant (ICPP). As a new program, efforts are just getting underway toward addressing major issues related to the fuel and waste stored at the ICPP. The SF\&WMTDP has the following principal objectives:

Investigate direct dispositioning of spent fuel, striving for one acceptable waste form

Determine the best treatment process(es) for liquid and calcine wastes to minimize the volume of high level radioactive waste (HLW) and low level radioactive waste (LLW)

- Demonstrate the integrated operability and maintainability of selected treatment and immobilization processes

Assure that implementation of the selected waste treatment process is environmentally acceptable, ensures public and worker safety, and is economically feasible. 


\section{CONTENTS}

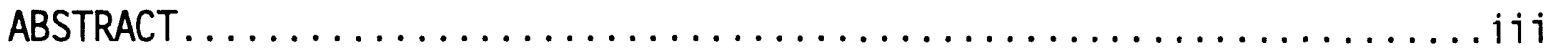

ACRONYMS $\ldots \ldots \ldots \ldots \ldots \ldots \ldots \ldots \ldots \ldots \ldots \ldots \ldots \ldots \ldots \ldots \ldots \ldots \ldots$

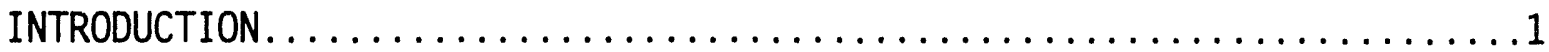

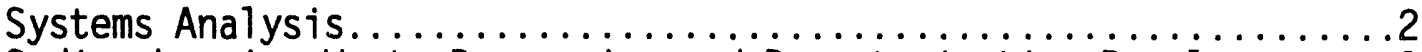
Sodium-bearing Waste Processing and Decontamination Development. . .3

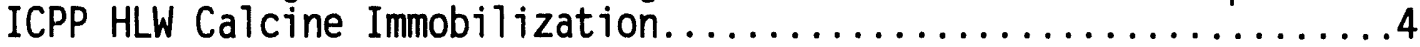
Graphite Fuels Disposal........................... 5 Treatment of Special Fuels for Disposal..................

Radioactive Scrap Metal Recycle........................6

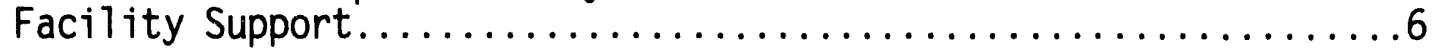

SYSTEMS ANALYSIS ..............................

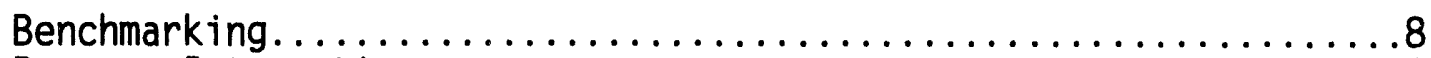

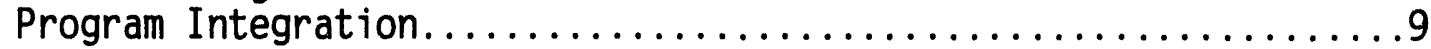

Performance Assessment. .............................. 10

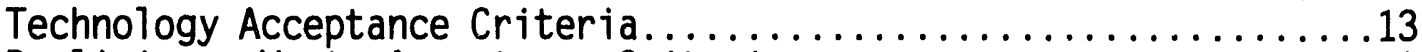

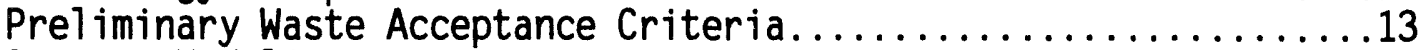

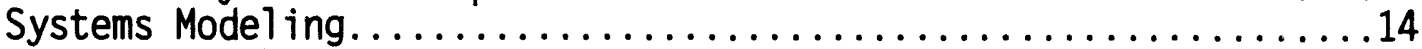

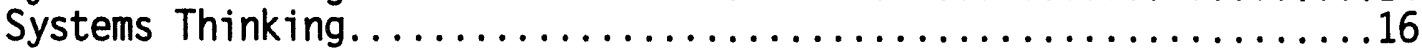

Westinghouse GOCO Cross Cultivation Effort.................... 18

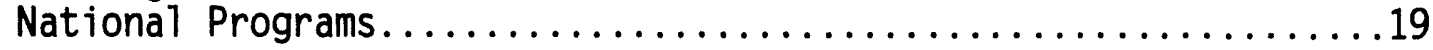

SODIUM-BEARING WASTE PROCESSING AND DECONTAMINATION DEVELOPMENT .....22

Decontamination Technologies........................22

Simulated Contamination (SIMCON) Development..........22

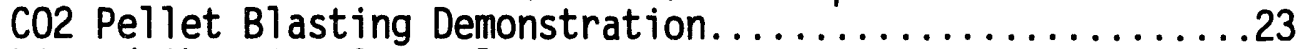

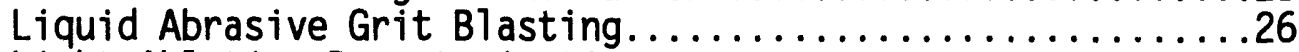

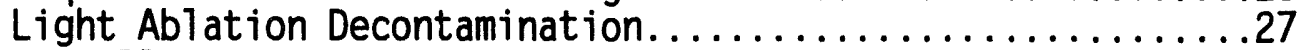

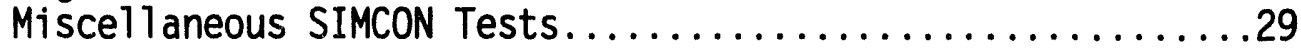

Sodium-bearing Waste Technologies.........................

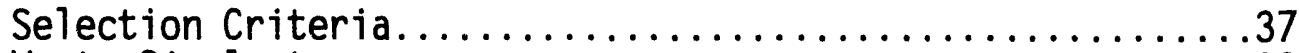

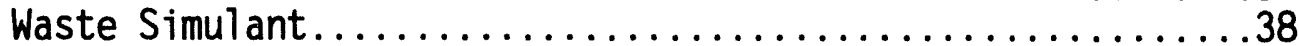

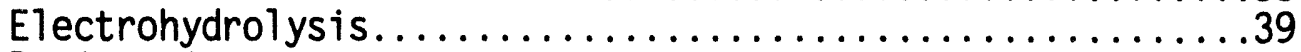

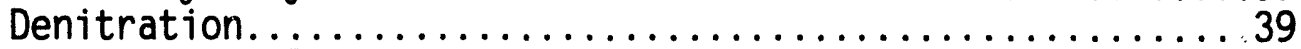

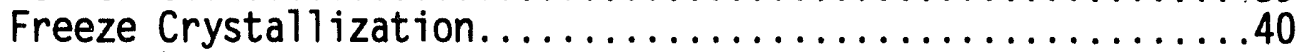

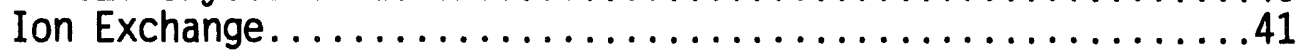

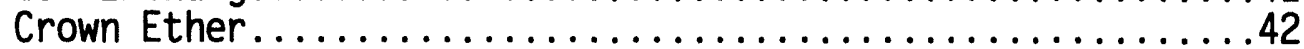

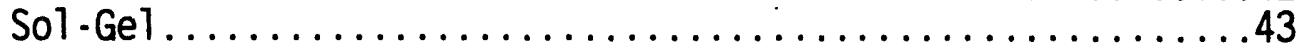

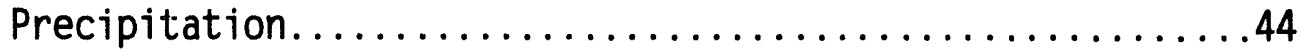

Pilot Plants.............................. 44

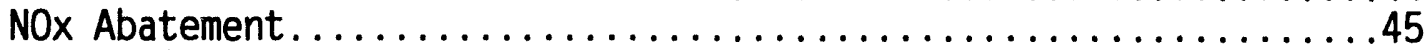

HEPA Filter Leaching......................... 47

Tank Farm................................. 


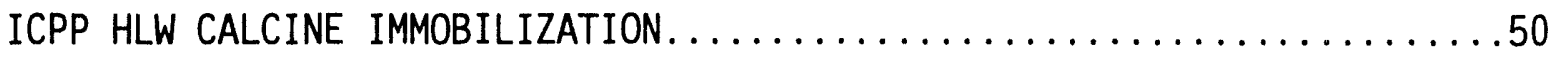

Waste Acceptance/Waste Form. . . . . . . . . . . . . . . . . . . . . 50

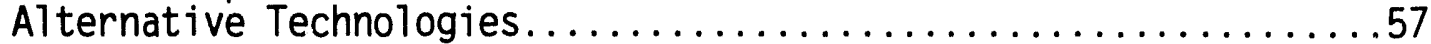

Process Development.............................64

Calcine Retrieval............................... 70

GRAPHITE FUELS DISPOSAL $\ldots \ldots \ldots \ldots \ldots \ldots \ldots \ldots \ldots \ldots \ldots \ldots$

Disposal Criteria..............................

Graphite Block Processing/Dissassembiy...................

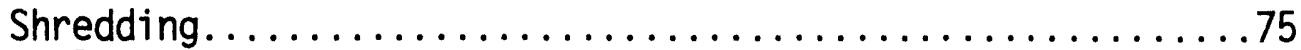

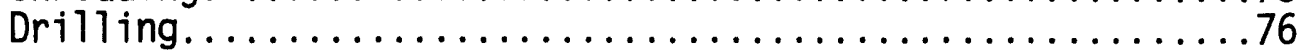

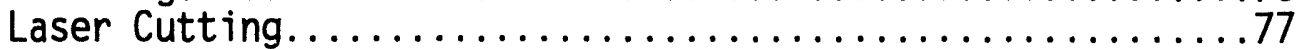

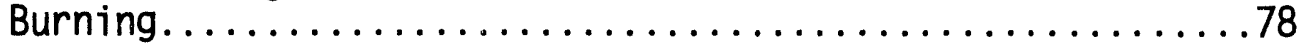

Characterization/Examination...................... 80

TREATMENT OF SPECIAL FUELS FOR DISPOSAL $\ldots \ldots \ldots \ldots \ldots \ldots \ldots \ldots \ldots$

Fuel Characterization/Database.................... 83

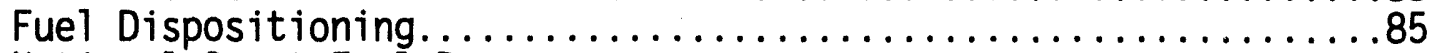

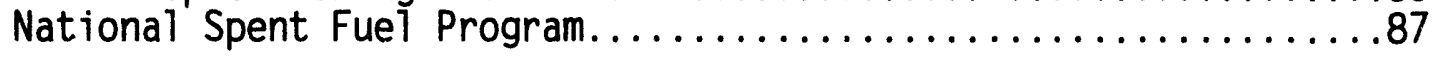

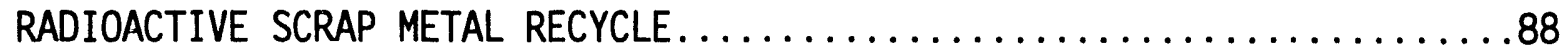

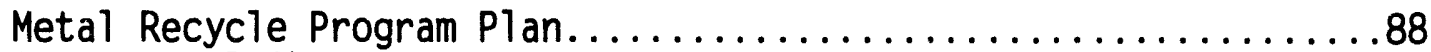

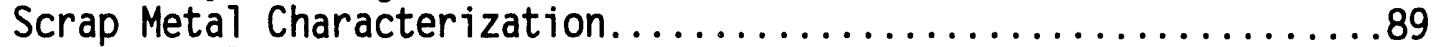

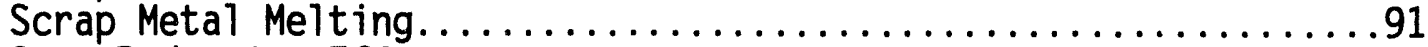

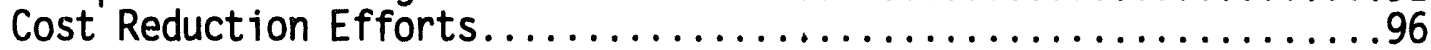

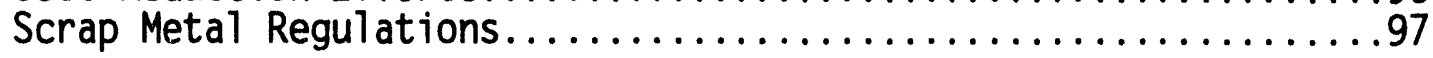

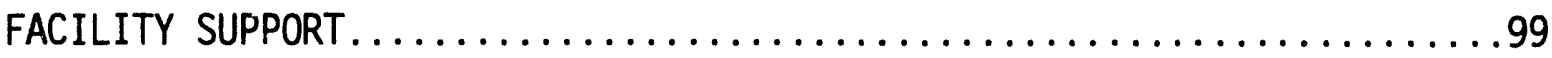

Evaluation of Potential Uses of FDP and FPR.............99

Space Requirements Study/Facility Requirements Evaluation.......99

Hot Cells/Other Facilities.............................. 100

Environmental Permits/Air Emissions Study..................... 102

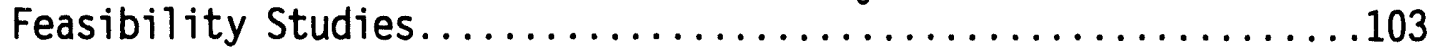

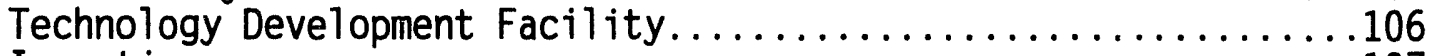

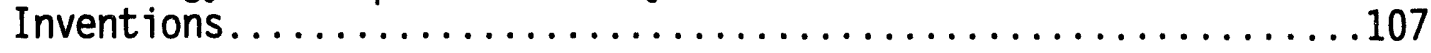

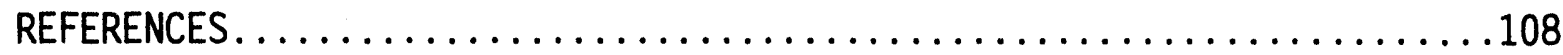




\begin{tabular}{|c|c|c|c|}
\hline AFPP & $\begin{array}{l}\text { Acid Fractionator } \\
\text { Pilot Plant }\end{array}$ & CERCOMP & $\begin{array}{l}\text { Ceramic } \\
\text { composition } \\
\text { program }\end{array}$ \\
\hline ALARA & $\begin{array}{l}\text { as low as } \\
\text { reasonably } \\
\text { achievable }\end{array}$ & CFR & $\begin{array}{l}\text { Code of Federal } \\
\text { Regulations }\end{array}$ \\
\hline $3 \mathrm{Al}_{2} \mathrm{O}_{3} \cdot 2 \mathrm{SiO}_{2}$ & mullite & CGS & $\begin{array}{l}\text { Calcine Grinder } \\
\text { Setup }\end{array}$ \\
\hline $\begin{array}{l}\mathrm{Al}_{2} \mathrm{O}_{3} \\
\text { ANL }\end{array}$ & $\begin{array}{l}\text { aluminum oxide } \\
\text { Argonne National } \\
\text { Laboratory }\end{array}$ & CIPP & $\begin{array}{l}\text { Calcine } \\
\text { Immobilization } \\
\text { Pilot Plant }\end{array}$ \\
\hline ANN & aluminum nitrate & CMPO & TRUEX extractant \\
\hline ANSTO & $\begin{array}{l}\text { Australian Nuclear } \\
\text { Service and } \\
\text { Technology } \\
\text { Organization }\end{array}$ & $\begin{array}{l}\mathrm{CO}_{2} \\
\text { CRADA }\end{array}$ & $\begin{array}{l}\text { carbon dioxide } \\
\text { Cooperative } \\
\text { Research and } \\
\text { Development }\end{array}$ \\
\hline APS & $\begin{array}{l}\text { Atmospheric } \\
\text { Protection System }\end{array}$ & & Agreement \\
\hline \multirow[t]{2}{*}{ ASME } & \multirow{2}{*}{$\begin{array}{l}\text { American Society } \\
\text { of Mechanical } \\
\text { Engineers }\end{array}$} & CSE & $\begin{array}{l}\text { Criticality Safety } \\
\text { Evaluation }\end{array}$ \\
\hline & & CSS & $\begin{array}{l}\text { Calcine Stabilizer } \\
\text { Setup }\end{array}$ \\
\hline B\&W & $\begin{array}{l}\text { Babcock and Wilcox } \\
\text { Idaho } \\
\text { boron oxide }\end{array}$ & CSSF & $\begin{array}{l}\text { Calcine Solids } \\
\text { Storage Facilities }\end{array}$ \\
\hline \multirow[t]{2}{*}{ BDAT } & \multirow{2}{*}{$\begin{array}{l}\text { Best Demonstrated } \\
\text { Avail lable } \\
\text { Technology }\end{array}$} & $c x$ & $\begin{array}{l}\text { categorical } \\
\text { exclusion }\end{array}$ \\
\hline & & D\&D & $\begin{array}{l}\text { Decontamination } \\
\text { and }\end{array}$ \\
\hline BYU & $\begin{array}{l}\text { Brigham Young } \\
\text { University }\end{array}$ & & Decommisssioning \\
\hline $\mathrm{CaAl}_{2} \mathrm{Si}_{2} \mathrm{O}_{8}$ & anorthite & DFs & $\begin{array}{l}\text { decontamination } \\
\text { factors }\end{array}$ \\
\hline $\begin{array}{l}\mathrm{CaSiO}_{3} \\
\mathrm{CBD}\end{array}$ & $\begin{array}{l}\text { alpha-Wollastonite } \\
\text { Commerce Business } \\
\text { Daify }\end{array}$ & DNFSB & $\begin{array}{l}\text { Defense Nuclear } \\
\text { Facility Safety } \\
\text { Board }\end{array}$ \\
\hline \multirow[t]{2}{*}{ CERCLA } & \multirow{2}{*}{$\begin{array}{l}\text { Comprehensive } \\
\text { Environmental } \\
\text { Response, } \\
\text { Compensation, and } \\
\text { Liability Act }\end{array}$} & DOE & $\begin{array}{l}\text { Department of } \\
\text { Energy }\end{array}$ \\
\hline & & DOE-EH & $\begin{array}{l}\text { DOE Office of } \\
\text { Environment. } \\
\text { Safety and Health }\end{array}$ \\
\hline
\end{tabular}




\begin{tabular}{|c|c|c|c|}
\hline $\mathrm{DOE} \cdot \mathrm{HQ}$ & DOE-Headquarters & GLC & Great Lakes Carbon \\
\hline DOE-ID & DOE-Idaho & \multirow[t]{2}{*}{ GOCO } & Government Owned \\
\hline EA & $\begin{array}{l}\text { Environmental } \\
\text { Assessment }\end{array}$ & & Operated \\
\hline ECD & $\begin{array}{l}\text { Environmental } \\
\text { Control Division }\end{array}$ & HAW & $\begin{array}{l}\text { high activity } \\
\text { waste }\end{array}$ \\
\hline ED & electrodialysis & \multirow[t]{2}{*}{ HCWHNF } & $\begin{array}{l}\text { Hazardous Chemical } \\
\text { Waste Handling } \\
\text { Facility }\end{array}$ \\
\hline EH & electrohydrolysis & & \\
\hline EIS & $\begin{array}{l}\text { Environmental } \\
\text { Impact Statement }\end{array}$ & HEPA & $\begin{array}{l}\text { High Efficiency } \\
\text { Particulate Air }\end{array}$ \\
\hline \multirow[t]{2}{*}{ EM } & \multirow{2}{*}{$\begin{array}{l}\text { DOE Office of } \\
\text { Environmental } \\
\text { Restoration and } \\
\text { Waste Management }\end{array}$} & HFEF & $\begin{array}{l}\text { Ext Fuel } \\
\text { Examination } \\
\text { Facility }\end{array}$ \\
\hline & & HIP & $\begin{array}{l}\text { hot isostatic } \\
\text { press }\end{array}$ \\
\hline EPA & $\begin{array}{l}\text { Environmental } \\
\text { Protection Agency }\end{array}$ & $H L W$ & $\begin{array}{l}\text { high level } \\
\text { radioactive waste }\end{array}$ \\
\hline ES\&H & $\begin{array}{l}\text { Environment, } \\
\text { Safety and Health }\end{array}$ & $\mathrm{HNO}_{3}$ & nitric acid \\
\hline F\&OR & $\begin{array}{l}\text { Facility and } \\
\text { Operational } \\
\text { Requirements }\end{array}$ & HTGR & $\begin{array}{l}\text { High Temperature } \\
\text { Gas-cooled Reactor }\end{array}$ \\
\hline FC & $\begin{array}{l}\text { freeze } \\
\text { crystallization }\end{array}$ & HVAC & $\begin{array}{l}\text { heating, } \\
\text { ventilating, and } \\
\text { air conditioning }\end{array}$ \\
\hline FDP & $\begin{array}{l}\text { Fluorinel } \\
\text { Dissolution } \\
\text { FProcess }\end{array}$ & ICPAES & $\begin{array}{l}\text { Inductively } \\
\text { Coupled Plasma } \\
\text { Atomic Emission } \\
\text { Spectroscopy }\end{array}$ \\
\hline FPR & $\begin{array}{l}\text { Fuel Processing } \\
\text { Restoration }\end{array}$ & ICPP & $\begin{array}{l}\text { Idaho Chemical } \\
\text { Processing Plant }\end{array}$ \\
\hline FSV & Fort St. Vrain & \multirow{2}{*}{ IFR } & \multirow{2}{*}{$\begin{array}{l}\text { Integral Fast } \\
\text { Reactor }\end{array}$} \\
\hline \multirow[t]{2}{*}{ FTC } & $\begin{array}{l}\text { Freeze } \\
\text { Technologies }\end{array}$ & & \\
\hline & $\begin{array}{l}\text { Corporation. Inc. } \\
\text { fiscal year }\end{array}$ & IFSF & $\begin{array}{l}\text { Irradiated Fuel } \\
\text { Storage Facility }\end{array}$ \\
\hline GA & General Atomics & INEL & $\begin{array}{l}\text { Idaho National } \\
\text { Engineering } \\
\text { Laboratory }\end{array}$ \\
\hline
\end{tabular}




\begin{tabular}{|c|c|c|c|}
\hline ISU & $\begin{array}{l}\text { Idaho State } \\
\text { University }\end{array}$ & $\mathrm{NaNO}_{3}$ & sodium nitrate \\
\hline IWIF & Idaho Waste & $\mathrm{NaOH}$ & sodium hydroxide \\
\hline & $\begin{array}{l}\text { Immobilization } \\
\text { Facility }\end{array}$ & NEPA & $\begin{array}{l}\text { National } \\
\text { Environmental } \\
\text { Policy Act }\end{array}$ \\
\hline LANL & $\begin{array}{l}\text { Los Alamos } \\
\text { National } \\
\text { Laboratory }\end{array}$ & NESHAPS & $\begin{array}{l}\text { National Emission } \\
\text { Standards for } \\
\text { Hazardous Air }\end{array}$ \\
\hline LATA & $\begin{array}{l}\text { Los Alamos } \\
\text { Technical }\end{array}$ & & Pollutants \\
\hline & Associates & NFS & $\begin{array}{l}\text { Nuclear Fuel } \\
\text { Services }\end{array}$ \\
\hline LDR & $\begin{array}{l}\text { Land Disposal } \\
\text { Restriction }\end{array}$ & $\mathrm{NH}_{3}$ & ammonia \\
\hline LLNL & $\begin{array}{l}\text { Lawrence Livermore } \\
\text { National }\end{array}$ & $\mathrm{NH}_{4} \mathrm{NO}_{3}$ & ammonium nitrate \\
\hline & Laboratory & NON & $\begin{array}{l}\text { Notice of } \\
\text { Noncompliance }\end{array}$ \\
\hline LLW & $\begin{array}{l}\text { low level } \\
\text { radioactive waste }\end{array}$ & $\mathrm{NO}_{\mathrm{x}}$ & oxides of nitrogen \\
\hline LTWM & $\begin{array}{l}\text { long term waste } \\
\text { management }\end{array}$ & NPR & $\begin{array}{l}\text { New Production } \\
\text { Reactor }\end{array}$ \\
\hline LWR & $\begin{array}{l}\text { Light Water } \\
\text { Reactor }\end{array}$ & NRC & $\begin{array}{l}\text { Nuclear Regulatory } \\
\text { Commission }\end{array}$ \\
\hline$M$ & molar & NSNF & $\begin{array}{l}\text { National Spent } \\
\text { Nuclear Fuel }\end{array}$ \\
\hline MCC & $\begin{array}{l}\text { material } \\
\text { characterization } \\
\text { center }\end{array}$ & NTS & Nevada Test Site \\
\hline $\mathrm{MgO}$ & & NUHOMS ${ }^{\circledR}$ & $\begin{array}{l}\text { Nutech Horizontal } \\
\text { Modular Storage } \\
\text { System }\end{array}$ \\
\hline MPPF & $\begin{array}{l}\text { Multi-function } \\
\text { Pilot Plant } \\
\text { Facility }\end{array}$ & NWCF & $\begin{array}{l}\text { New Waste } \\
\text { Calcining Facility }\end{array}$ \\
\hline MSC & $\begin{array}{l}\text { Manufacturing } \\
\text { Science } \\
\text { Corporation }\end{array}$ & OGI & $\begin{array}{l}\text { Oregon Graduate } \\
\text { Institute of } \\
\text { Science and } \\
\text { Technology }\end{array}$ \\
\hline MSE & $\begin{array}{l}\text { Mountain States } \\
\text { Energy }\end{array}$ & ORNL & $\begin{array}{l}\text { Oak Ridge National } \\
\text { Laboratory }\end{array}$ \\
\hline $\mathrm{Na}_{2} \mathrm{CO}_{3}$ & sodium carbonate & & \\
\hline $\mathrm{Na}_{2} \mathrm{O}$ & sodium oxide & & \\
\hline
\end{tabular}


OTD

PA

PBF

PDF

PGE

PIE

PNL

PREPP

PSC

PSD

PTC

PWAC

QA

R\&D

RAL

RCRA
EM-50 Office of

Technology

Development

Performance

Assessment

Power Burst

Facility

Production

Development

Facility

Portland General

Electric

post irradiation

examination

Pacific Northwest

Laboratories

Process

Experimental Pilot

Plant

Public Services of Colorado

Prevention of

Significant

Deterioration

Permit to

Construct

Prel iminary Waste Acceptance

Criteria

Qual ity Assurance

research and

development

Remote Analytical

Facility

Resource

Conservation

Recovery Act
RFP

RSM

$\mathrm{RW}$

SBW

SCR

SEG

SEM

SF\&WMTDP

$\mathrm{SiO}_{2}$

SMC

SNAP

SNF

SNL

$\mathrm{SO}_{\mathrm{x}}$

SO

SRS
Request for

Proposal

radioactive scrap meta1

DOE Office of Civilian Radioactive Waste Management

sodium-bearing waste

selective catalytic reduction

Scientific Ecology Group

Scanning Electron Microscope

Spent Fuel and Waste Management Technology Development Program

silica

Special

Manufacturing

Capabilities

Systems for Nuclear Auxiliary Power

spent nuclear fuel

Sandia National

Laboratories

oxides of sulfur

Systems

Operability

Savannah River

Site 


$\begin{array}{llll}\text { SRTC } & \begin{array}{l}\text { Savannah River } \\ \text { Technical Center }\end{array} & \text { URU } & \text { unrestricted use } \\ \text { SS } & \text { VE } & \text { Value Engineering } \\ \text { TAN } & \text { Test Area North } & \text { VOG } & \text { vessel off-gas } \\ \text { TCLP } & \begin{array}{l}\text { VRF } \\ \text { toxicity } \\ \text { characteristic } \\ \text { leaching procedure }\end{array} & \text { WAC } & \begin{array}{l}\text { volume reduction } \\ \text { factor }\end{array} \\ \text { TDF } & \begin{array}{l}\text { Technology } \\ \text { Development }\end{array} & \text { WCF } & \begin{array}{l}\text { waste acceptance } \\ \text { criteria }\end{array} \\ \text { Facility } & \text { Waste Calcining } \\ \text { TRA } & \text { Test Reactor Area } & \text { WINCO } & \begin{array}{l}\text { Facility } \\ \text { Westinghouse Idaho } \\ \text { Nuclear Company, } \\ \text { Inc. }\end{array} \\ \text { TRU } & \begin{array}{l}\text { transuranic } \\ \text { transuranic } \\ \text { extraction process }\end{array} & \text { WIPP } & \begin{array}{l}\text { Waste Isolation } \\ \text { Pilot Plant }\end{array} \\ \text { TRUEX } & \begin{array}{l}\text { Technical Working } \\ \text { Group }\end{array} & \text { YAG } & \begin{array}{l}\text { yttrium aluminum } \\ \text { garnet }\end{array} \\ \text { TWG } & \begin{array}{l}\text { United Engineers } \\ \text { and Contractors }\end{array} & \text { YMP } & \begin{array}{l}\text { Yucca Mountain } \\ \text { Project }\end{array} \\ \text { UE\&C } & & & \end{array}$




\section{SPENT FUEL AND WASTE MANAGEMENT TECHNOLOGY DEVELOPMENT PROGRAM}

\section{INTRODUCTION}

The Spent Fuel and Waste Management Technology Development Program (SF\&WMTDP) was initiated in fiscal year (FY) 1992 at the Idaho Chemical Processing Plant (ICPP), and began receiving funding in July 1992. As a new program, efforts are just getting underway toward addressing major issues related to the fuel and waste stored at the ICPP.

The SF\&WMTDP has established the following principal objectives:

- Investigate direct dispositioning of spent fuel, striving for one acceptable waste form.

- Determine the best treatment process(es) for liquid and calcine wastes to minimize the volume of high level radioactive waste (HLW) and low level radioactive waste (LLW).

- Demonstrate the integrated operability and maintainability of selected treatment and immobilization processes.

Assure that implementation of the selected waste treatment process is environmentally acceptable, ensures public and worker safety, and is economically feasible.

The strategy for achieving these objectives includes:

Capitalizing on all available technology, both National and International.

- Utilizing a systems approach during development, which will take into account all of the factors that may impact final dispositioning of spent fuels and waste.

Efforts required to support the Development Program fall into three principal categories:

Developing the basis for integrated strategic decisions aimed at 
justifying the best technologies for waste and spent fuel processing and preparation for dispositioning.

- Developing Best Demonstrated Available Technologies (BDAT) for radioactive sodium-bearing liquid waste (SBW), calcine, and Department of Energy (DOE) owned spent fuels.

- Providing facilities necessary to develop and demonstrate candidate processing and disposal technologies.

The SF\&WMTDP is divided into the areas of Systems Analysis; SodiumBearing Waste Processing and Decontamination Development; ICPP HLW Calcine Immobilization: Graphite Fuels Disposal; Treatment of Special Fuels for Disposal: Radioactive Scrap Metal Recycle; and Facility Support.

A description of each program follows.

\section{Systems Analysis}

A primary condition for acceptance of spent fuels and HLW in repositories within the United States is a demonstrated long-term storage technique that will comply with several laws and regulations. The Code of Federal Regulations (CFR) 10 Part 60 (Disposal of High-Level Radioactive Wastes in Geologic Repositories): 40 CFR Part 191 (Environmental Radiation Protection Standards for Management and Disposal of Spent Nuclear Fuel, HighLevel and Transuranic Radioactive Waste): Nuclear Regulatory Commission (NRC) licensing; the National Environmental Policy Act (NEPA); and potentially Subpart B, the Resource Conservation Recovery Act (RCRA) are the major regulations that define these requirements. It is recognized that unequivocal proof of compliance with standards is not possible because of the substantial uncertainties in predicting future human actions or natural events. Therefore, the Environmental Protection Agency (EPA) expects compliance to be determined based on specified quantitative analyses and informed qualitative judgement. Systems Analysis has primary responsibility for these analyses for the SF\&WMTDP. 
Systems Analysis will also integrate information from and requirements for the SF\&WMTDP, and will address spent fuel and waste by developing strategic decision making models. The models will consider technical and institutional factors that affect treatment and disposal options to optimize the dispositioning of the spent fuel and waste. These model analysis results will be shared with other research sections involved with the program to aid in the development of optimized acceptable waste forms. As the development program generates new information and as repository criteria are completed. new variable data will be developed and incorporated into the model for updated analysis, the results of which will be used to make strategic decisions and to identify and help resolve outstanding issues.

\section{Sodium-bearing Waste Processing and Decontamination Development}

Sodium-bearing Waste (SBW), a radioactive mixed waste, has been produced from uranium recovery, off-gas treatment, solvent recovery, and decontamination operaitions at the ICPP since the mid 1950s. Currently there are approximately 1.5 million gallons of SBW stored in six 300,000 gallon capacity underground HLW tanks. The established method for disposing of SBW has been fluidized-bed calcination by blending it with fuel reprocessing raffinates to dilute the sodium concentration. SBW cannot be calcined by itself due to melting and agglomeration of sodium and potassium salts at the calcination temperature of $500^{\circ} \mathrm{C}$. However, with the April 1992 decision to curtail fuel reprocessing, raffinate waste will no longer be available for blending with the SBW.

An option of blending the SBW with non-radioactive aluminum nitrate (ANN) has been the only alternative previously investigated. However, the addition of non-radioactive stock chemicals, such as ANN, to a radioactively contaminated waste stream is unattractive due to the increased volume and. therefore, increased calcination, storage, immobilization and repository disposal costs.

Under current RCRA Land Disposal Restriction (LDR) regulations, this waste must be treated with the BDAT prior to land disposal. In addition, the Consent Order for the 1990 ICPP tank farm Notice of Noncompliance (NON) requires that the SBW be depleted from the pillar and panel tanks (WM-182, 
WM-183, WM-184, WM-185 and WM-186) by 2009, and the remainder of the tanks by 2015. Therefore, efforts to develop a BDAT are needed to: (1) qualify a cost effective method for processing SBW into a final low volume waste form, and (2) verify new decontamination methods that either eliminate the use of sodium, recycle the current inventory of sodium, or are compatible with the SBW disposal method developed.

\section{ICPP HLW Calcine Immobilization}

The ICPP has converted HLW generated from fuel dissolution to a granular solid (calcine) for over 30 years. This work was first done in the Waste Calcining Facility (WCF); and after 1982, in the New Waste Calcining Facility (NWCF). The calcine is considered a radioactive mixed waste by current RCRA regulations. The ICPP has generated and is temporarily storing over 3,800 cubic meters of calcine in stainless steel bins. Additional calcine will be generated in the future as the NWCF processes both the waste currently stored in the tank farm and potentially future waste generated by decontamination of the various facilities. All calcine generated at ICPP will need to be processed into an acceptable immobilized form for final disposal.

The Calcine Immobilization Program will develop and demonstrate processes to immobilize ICPP calcine in an acceptable form (one that minimizes leachability of the waste constituents) at a minimum volume. Development and demonstration will include:

Evaluating alternative technologies for feasibility and overall volume reduction benefit.

Developing waste form formulations for the calcine types stored at ICPP.

Developing disposal criteria to comply with EPA and NRC regulations,

Developing the required processes for converting the calcine to an immobilized waste form for final disposal, and

Developing the equipment required to retrieve calcine from the existing Calcine Solids Storage Facilities (CSSF). 
Implementation encompasses providing the design criteria and technical support to ensure that a full-scale immobilization facility can be constructed and operated.

This program supports the Federal Facilities Compliance Agreement/Concent Order currently being negotiated, by DOE, with the State of Idaho. The Idaho Waste Immobilization Facility (IWIF) is listed in this document as being available to convert calcine into an immobilized form.

\section{Graphite Fuels Disposal}

Graphite fuel stored at the ICPP includes mainly Fort St. Vrain (FSV) (290 Metric Tons) and Peach Bottom spent fuels, with much smaller quantities of Rover and Parka fuels. The stored FSV fuel comprises three segments (726 blocks) from the reactor, with an additional six segments (1516 blocks) potentially available for receipt and storage. All ICPP graphite fuels are in dry storage either in the Irradiated Fuel Storage Facility (IFSF) or in underground silos.

The Graphite fuel program will evaluate alternatives for graphite fuel disposal in a safe and efficient manner while meeting EPA, NRC, and other environmental constraints or criteria. Identified disposal alternatives will be evaluated until proven to be unfeasible or significantly inferior to other alternatives, at which time the alternative will be eliminated from further development work. Upon selection of feasible alternative disposal means or processes, each will be developed through successive steps of laboratory process verification, and component/subsystem testing until the best alternative is selected for full scale or near full scale system testing prior to construction of a graphite fuel disposal facility.

\section{Ireatment of Special Fuels for Disposal}

There are over 90 identified types of special nuclear fuel at the Idaho National Engineering Laboratory (INEL) and well over 100 types in the DOE complex, a high percentage of which have not been characterized. These fuels must be characterized, waste form disposal criteria developed, regulatory 
requirements interpreted, and candidate disposal technologies identified. Laboratory and component testing of candidate processes will be performed, and pilot plant (PP) and hot integrated testing of the selected process will be carried out to verify the process before the operating facility is designed. Ongoing interfacing with regulatory agencies will take place to develop and follow disposal requirements and options.

\section{Radioactive Scrap Metal Recycle}

Westinghouse Idaho Nuclear Company, Inc. (WINCO) will provide lead support to the DOE Office of Environmental Restoration and Waste Management (EM) Office of Waste Management (EM-30) to address al1 issues of radioactive scrap metal (RSM) management and coordination of DOE's RSM activities, with emphasis on recycle and beneficial reuse. Supporting program elements include: project management, source compilations, regulations/criteria, systems analysis/life cycle cost estimates, decontamination, industrial interfaces/technology transfer, recycle concepts, and stainless steel (SS) melt technology.

\section{Eacility Support}

Research and development for new candidate process technologies needed to process the various hazardous wastes and spent fuels is currently being done at the laboratory scale. Demonstration, evaluation and verification of candidate technologies is a prerequisite for the design of future processing facilities. The various technology development programs cannot be carried out concurrently in existing pilot plant space. A preliminary facility evaluation of potential pilot plant space in existing facilities indicates that available space is insufficient for cold and hot pilot plant operations of the development program. Additional new pilot plant space, including hot cell facilities, is needed to support the SF\&WMTDP.

The activities in this program will result in a Multi-function Pilot Plant Facility (MPPF) that provides test bays and remotely operated hot cells. with installed utility and electrical systems, flexibly configured to support an evolving pilot plant program. The MPPF is needed to develop and demonstrate the integrated operability and maintainability of selected 
processes for fuel disposal, HLW disposal, and decontamination process development. The MPPF will be used for component and subsystem testing and small scale hot pilot plant testing. The MPPF will also allow efficient test assembly set up and change to expedite research and development (R\&D) pilot plant work.

This program will coordinate efforts to meet the facility requirements of the SF\&WMTDP. It will provide support for adequate reviews of pilot plant designs, prepare environmental documentation, provide a coordinated effort for use of existing facilities, provide engineering oversight of pilot plant designs and changes in existing pilot plant areas, and assist in developing the technical requirements for new pilot plant space. The prime objective of the effort will be to maximize the use of existing facilities and minimize the requirements for new facilities.

This program will evaluate existing ICPP facilities for use as cold pilot plants. Existing ICPP facilities originally intended for other uses (i.e., the Fuel Processing Restoration (FPR), the Fluorinel Dissolution Process (FDP) Facility, Main Process Facility CPP.601, Hot Pilot Plant CPP. 640. Hot Chemistry Lab and Remote Analytical Facility (RAL) in CPP 627. Craftshop and Warehouse Building CPP.655, and various other ICPP facilities) will be evaluated for use as R\&D and/or production facilities for spent fuel and waste disposal. The existing development space in CPP-637/620 will be evaluated and coordinated for optimal usage. Beyond use of the existing facilities, new facility space will provide additional laboratory space for Sodium Waste disposal, Decontamination Development, Calcine Solidification. and Spent Fuel disposal research and development pilot plant testing. 


\section{SYSTEMS ANALYSIS}

\section{Benchmarking}

As a new technology development program, it was necessary to identify existing technologies that might have applicability to the INEL SF\&WMTDP: identifying and considering available technologies could help establish the credibility of our program. It was also necessary to make the presence of the technology development program known and to establish contacts with appropriate personnel within the DOE and its contractor organizations. As a result, a number of trips were taken with these ends in mind.

A trip to benchmark French, British, Belgian, and German vitrification/waste management technology was taken in October 1992. Tours and discussions were held concerning prototype testing, construction, and operation of vitrification production facilities. Examples of other areas of interest included a promising new approach to glass and metal melting using a "cold crucible" melter, under development by the French, and repository performance assessment methodology, developed by the Germans. A foreign trip report was issued following this trip.

The WINCO SF\&WMTDP Director met with Hlanford and Savannah River Site (SRS) personnel in December 1992 and January 1993 to discuss potential areas for cost saving through sharing. Follow-up actions involving possible sharing in the areas of Waste Management. Grouting. Actinide Separation. Decontamination, and Vitrification Technologies, as well as Technology Transfer, were pursued.

The WINCO Program Director attended the Institute of Nuclear Material Management Spent Fuel Management Seminar and met with DOE-Headquarters (DOEHQ) personnel in Washington, D.C. in January 1993 to discuss the SF\&WMTDP. A number of other meetings were held at various locations to discuss Performance Assessment efforts, the spent fuel program, the SBW program, and the technology development program in general. 


\section{Program Integration}

Comments from DOE-Idaho (DOE-ID) regarding the 5-year detailed program plans completed in FY.92 as major milestones were received and resolved. Due to changes in focus for the Technology Development program, including efforts to develop a global perspective for the dispositioning options available to the development program, a number of planning activities were performed.

A meeting attended by representatives from all Applied Technology Development sections, as well as WINCO's Strategic Planning. Projects, and Environmental groups, was held at the Idaho State University (ISU) Simplot Decision Center to clarify program objectives and to draft a comprehensive Level I program schedule. A steering committee was established to continue this planning and issue an updated program planning document to clearly define key program decision points, establish criteria for each and identify supporting program activities. Several drafts of the updated Idaho Chemical Processing Plant Spent Fuel and Waste Management Technology Development Program Plan. ${ }^{1}$ were prepared and reviewed, with the document being restructured to better reflect the changing direction of the program and consider company strategic planning. The document was issued to DOE-ID at the end of September 1993.

Initially the technology development program began looking at a large number of technologies to handle the various waste forms. It was decided that this approach would take an undue amount of money and time to decide on final process technologies. As a result, a Process Core Group was formed to develop a limited number of process flowsheets, centered around technologies being studied, to focus development activities. One of the aims of this group was to develop global flowsheets that could be used to handle all ICPP waste types as well as other INEL and DOE wastes. Considerable effort was placed in this area, resulting in the development of several potential flowsheets. Peer reviews were conducted to validate the results of these efforts.

An integrated program schedule was developed, and the earned value system implemented to complete a March 31, 1993 milestone. 
Department scheduling needs were supported by developing a usage schedule for the FDP cell to facilitate integratirg hot pilot plant work with other ongoing work, assisting with preparation of a detailed FY.93 plan for Calcine Immobilization Process Development, and preparing a schedule for the establishment of Preliminary Waste Acceptance Criteria.

\section{Performance Assessment}

A preliminary Repository Performance Assessment (PA) is being performed to simulate confinement of waste forms in postulated repository situations. The assessment is initially based on general physical knowledge such as rock type and characteristics, water depth and movement, and volcanic and seismic activity. The PA will address a range of geologic parameters that would envelope potential geologic media, and characteristics of the waste form. repository location, and repository design will be integrated into the analysis as they become available. The PA provides a basis for development of repository waste acceptance criteria that defines what types of wastes and spent fuel treatments are necessary to assure compliance with repository requirements.

A contract with Sandia National Laboratories (SNL) to perform the PA was established in FY-92. An interactive technical information exchange meeting between WINCO and SNL personnel was held at the ICPP to clarify the needs and responsibilities for the repository PA. The meeting produced agreement on the requirements for the waste and fuel form data that WINCO was to supply to SNL and allowed the clarification of both parties' needs. A presentation by SNL increased WINCO's level of understanding of the nature of the PA. The cumulative distribution function and how it is used in the assessment was explained as well.

A Yucca Mountain Project (YMP) Nuclear Waste Technical Review Board meeting and a tour of the Yucca Mountain Site were attended by several WINCO personnel in October 1992. The meeting provided insight into the work being done on the Yucca Mountain PA and identified several areas that WINCO needed to ensure were covered in the PA being performed by SNL. The areas of concern identified from the meeting were transmitted to SNL by letter and by phone communication. 
A meeting was held with SNL on November 10, 1992, to (1) review comments brought up by the YMP Nuclear Waste Technical Review Board during the October meeting. (2) review SNL's monthly progress report content and format, and (3) exchange information on the progress of the PA effort. A11 issues were resolved satisfactorily.

The formation of a Performance Assessment Oversight Review Pane1 consisting of knowledgeable personnel from the DOE Headquarters Program Office, DOE Idaho Field Office, DOE Waste Isolation Pilot Plant (WIPP) Program Integration Office, DOE Yucca Mountain Site Characterization Project Office. and the National Academy of Sciences was approved by DOE-ID, and the first meeting was held in February. 1993. Six separate documents, including program plans and other pertinent documents as well as meeting details, were forwarded to the review panel. The panel evaluated the assumptions, approach, direction, and scope of the PA. The general consensus of the review board was that, although there were several recommendations and national policy issues that need to be addressed, the current PA efforts are appropriate and should be continued. Many of the board's recommendations were incorporated into the FY-93 PA, and the balance will be addressed in future PA studies. WINCO and SNL developed resolutions to comments received from the INEL Performance Assessment Program Review and forwarded them, with additional documentation on the program review, to all meeting participants.

The INEL/ICPP spent fuels and waste description document ${ }^{2}$ was completed on schedule and forwarded to SNL to support the PA. This documentation fulfilled a major milestone in the WINCO/SNL PA contract. The documentation was presented in the form of a draft appendix to the final INEL PA report. A revision to the document was later completed and distributed for SNL use. An extensive internal technical review of the waste forms presented in the document was performed to ensure that the data needed for fuel conditioning and waste disposal program guidance, as well as systems modeling, can be obtained from the PA.

Another Performance Assessment milestone was met with the completion of a study of criticality safety issues associated with the burial of highly enriched nuclear fuel in a geologic repository. Results of this study were 
forwarded to SNL, where the issues identified were used in conducting the PA. This study will also be used as a basis for addressing criticality safety issues and the approaches that should be taken relative to the placement of High-Enriched Uranium in a geological repository.

The detailed PA calculations were initiated at the end of May and were completed at the end of July. Preliminary results indicated that the initial canister and over pack design may be too robust. The design contained an Inconel 625 canister with Ti Grade 12 over packs in the salt repository and Inconel 625 over packs in the igneous rock repository. With this design, the over pack and canister may last beyond the 10.000 year period. To ensure that the PA results would provide the relative performance of potential waste forms being considered, it was decided to use a reference 304L SS canister with no over pack in the detailed PA calculations.

An interactive meeting was held with SNL on June 22-23, 1993 to review the results that would be available when the FY.93 PA was completed and how to use the results to support the Technology Development Program decision process. An approach to developing a simplified PA model based on the results of the detailed PA evaluation was decided upon. This model will allow a simplified PA to be conducted at the INEL when the performance of a new waste form or question concerning an existing waste form is developed.

SNL completed all of the detailed PA calculations, and also developed simplified PA models (the same model used to conduct the Graphite Whole Block study). A draft Performance Assessment report was issued in September, in accordance with a DOE milestone. Various formal program and technical reviews of the results will be held during the October. December 1993 time frame.

Key FY.93 Ferformance Assessment conclusions include:

A11 waste forms evaluated comply with the total system performance requirement of 40 CFR 191.

Differences in waste treatments and forms have relatively small effects on the total system performance. Very extensive waste treatment is required to realize a conclusive improvement in the total system performance.

Backfill material composition is a key factor in total systems 
performance. A low permeable barrier as part of the containment system provides a great deal of benefit for little expense.

Highest probability of release to environment comes through 'cutting' (exploratory drilling) rather than from corrosion/leaching.

Waste disposal group 4 (U removed before burial) has the overall best systems performance.

\section{Technology Acceptance Criteria}

As part of the effort to develop technology acceptance criteria for the Technology Development programs, a Technology Acceptance Criteria Committee was established with the goal to develop matrix packages for each principal program area. Technology Acceptance Criteria were developed for each experimental program area, and the criteria include both a checklist of needed information and a decision tree (roadmap) describing how results will be obtained.

A Waste Definition and Disposal Criteria Committee was established to initially discern the definitions of and requirements for disposal of transuranic, low-level, and mixed waste. The purpose of the committee was to define a consistent set of criteria that can be applied to the Technology Development Program tasks involving separations of radionuclides and the resulting transuranic. low-level, and mixed wastes.

\section{Preliminary Waste Acceptance Criteria}

A Preliminary Waste Acceptance Criteria (PWAC) committee was formed to guide development of the PWAC. The committee held several meetings and identified the overall inter-relationship between the repository and the waste producer, and their individual responsibilities. The PWAC committee identified the need for a background section to provide the basis for and explain why WINCO is developing the PWAC. This background section is included as an appendix.

An initial draft of the PWAC document was completed. The PWAC committee finalized the contents and appendices of the PWAC, completed a detailed review of the document, and incorporated all the pertinent comments. The PWAC 
approach and outline of the PWAC were reviewed with DOE-ID, and a copy of the initial draft PWAC was provided to DOE-ID for information. The initial draft PWAC was provided to Lawrence Livermore National Laboratory (LLNL) to solicit their comments, and subsequent comments were incorporated. The draft PWAC was updated in July, as PA results became available, and was issued to DOE-ID on September 24, 1993 to meet the DOE milestone of September 30, 1993. A review meeting with both DOE-ID and WINCO personnel is planned for October, 1993. In addition, the PWAC will be transmitted for review to the Performance Assessment Program Review Panel and to the Integrated Spent Nuclear Fuel Program Technical Review Group.

\section{Systems Modeling}

Areas where small scale systems thinking simulations could meet immediate departmental needs were identified. The intent was to target one or two of these areas and provide a working simulation. This activity provided opportunities for Systems Analysis personnel to gain systems modeling experience, as well as to demonstrate the capabilities of systems analysis methods to Appl ied Technology personnel.

A model of ICPP NWCF operations, with and without a tank farm, was completed. The model supported an overall evaluation being conducted to evaluate the needs for a new tank farm at the ICPP. This model was used to generate qualitative operational results for inclusion in a larger report analyzing the need for the tanks. Experience with this model assisted in establishing the optimum sizing and need for the tank farm and for the new tank farm project. A report describing casual loop diagrams, model assumptions, and conclusions was written and issued.

Systems Modeling personnel attended a class in risk assessment that provided familiarization with the techniques of risk assessment for probable application to a risk assessment module.

A simplified computer program was developed to assist in compiling spent fuel radioactive source inventories: this program models reactor operation to establish actinide and daughter product inventories. 
Initial systems modeling efforts focused on canister and corrosion models. Using input obtained at a meeting with representatives from each of the development sections, conceptual models were developed. Programming was performed to build separate sections of the models, and the sections were integrated for debugging and operation of the models. The development of the initial canister and corrosion models was completed and the models were demonstrated to selected Applied Technology personnel. The initial response to both models was good, with some suggestions for model improvement being made. A Systems Analysis consultant made a visit to ICPP and participated in a lessons learned meeting on the initial models. The consultant made a few suggestions for incremental improvement, but in general felt that the WINCO initial efforts were going well. The corrosion and canister models were completed after incorporating suggested changes, and the canister model was converted from the Apple development platform to a format compatible with the WINCO IBM base. A user manual for the models was written and training on the use of models was provided to various personnel.

A Calcine Retrieval model was developed and completed. The model was designed to determine how different calcine retrieval scenarios affect the calcine compound concentrations and the associated scope of work for waste form development. A letter was issued describing the computer program, some initial analysis, and other potential uses in the Calcine Immobilization program. This completed a program milestone for the Calcine Immobilization Section.

Efforts to identify and define the different models in the strategic decision model were undertaken. Many of these models involve the modeling of "soft" variables, such as "public opinion" and, therefore require quality definition of the expected output from the module to allow proper framing of the tasks.

Meetings were held with Applied Technology personnel to identify issues and develop causal maps to support the evaluation of candidate technologies and processes. Construction of a Decision Support Tool (DST) began, based on the causal maps, and the scope of the DST was established. This tool, or computer model, was intended to assist with the evaluation of process options at the September-December 1993 initial decision point for the selection of 
candidate process technologies for future work in the SF\&WMTDP. The DST was designed as an internal support tool to evaluate the relations of "soft" variables to flowsheets and technology selection for the development program as a part of the overall selection process. Causal loops for the DST were constructed with the participation of representatives from all research program elements, and modeling of those loops was performed. The Decision Support Tool (DST) model was completed, and actions to validate and refine relations used in the model were undertaken.

The Laboratory Facilities Selection Tool, an expert system designed to assist in the selection of appropriate laboratory facilities based on the input of user requirements for a given set of experiments was also completed. This tool, along with the canister, corrosion, and DST models, satisfied the commitment to complete four models in FY-93. Other candidate models, including a facility queuing study and a model for the Metals Recycle program. were identified. The exact scope of these models was still being determined at the end of the year.

\section{Systems Thinking}

During the year a number of Systems Thinking techniques and tools were evaluated by the Systems Analysis section. Several of these tools are now being regularly used by Systems Analysis, including the Simplot Decision Center, hexagon analysis, structured analysis, and computer modeling.

The ISU Simplot Decision Center was visited by Systems Analysis personnel to assess its capabilities and to determine potential areas where it can provide strategic decision support. The capabilities of this facility were found to support the technology development program we11, and it was utilized several times during the year.

In conjunction with attendance at the annual Systems Thinking in Action Conference, potential consultants and software vendors in the Boston area were contacted to discuss WINCO's proposed methodology. The conference also provided an opportunity to attend software demonstrations and to identify some of the common elements of success and failure among other companies using systems thinking and simulation methods for strategic planning. 
WINCO and EG\&G Idaho jointly hosted a "Systems Thinking" training course provided by Innovation Associates. Inc., of Framingham. Massachusetts. The balance of the current Systems Analysis organization, as well as several representatives from other Applied Technology and WINCO organizations. attended the course.

Personnel attended training on the " $\mathrm{S} * \star 4$ " System Dynamics Simulation Software. This class was taught in Idaho Falls by the creator of the package. The class consisted of an introduction to $S * * 4$, followed by the creation of several short models to familiarize personnel with the capabilities of the language. specifically the ability to interface with and enhance the models created using the "I-Think" software package.

A Request for Proposal (RFP) was issued to obtain private consultant services to work with System Analysis and its customers to identify issues where simulation and modeling can be used most effectively, and to provide support for review and development of the initial WINCO modeling activities.

A contract to provide external validation of the modeling and strategic decision support efforts was awarded to Microworlds. Inc.. of Cambridge. Massachusetts. An initial visit to the ICPP was made the week of April 5-9. 1993. and the entire modeling approach and current models were reviewed and discussed. The contractor stated several times that he was very impressed by the speed at which the modeling capability was developed at WINCO, and provided numerous suggestions to help our activities.

A proposal to provide support to the technology development program was received from LLNL. This proposal was evaluated, and a response to the proposal was developed. A contract was initiated to obtain coaching and review/comment support in the areas of systems engineering, decision analysis, and waste acceptance criteria development.

An Applied Technology Department managers meeting, to identify issues related to short-term implementation of the revised SF\&WMTDP plan, was facilitated by David Kreutzer of Gould-Kreutzer Associates using the Hexagon Systems Thinking technique. The most important outcome of the meeting was solidifying the need for criteria to evaluate processing options for program 
planning. A number of additional issues were identified during the course of this meeting, and these are currently being pursued. Utilization of the hexagon technique resulted in enhanced understanding of the issues and concerns currently challenging the program.

Systems Integration personnel co-facilitated, with WINCO Strategic Planning personnel, meetings to support strategic planning in the areas of waste treatment and fuel receiving and dispositioning.

WINCO presented Systems Thinking techniques as tools to support Total Quality at the Westinghouse 1993 Benchmarking Symposium.

\section{Westinghouse GOCO Cross-Cultivation Efforts}

Several Westinghouse Cross-Cultivation meetings addressing aspects of the technology development program were attended by WINCO personnel.

A meeting of the Westinghouse Cross-Cultivation Committee Integration Group for High-Level Waste and the Defense Nuclear Facility Safety Board (DNFSB) was attended and a description of the extent of sharing technical information on vitrification was presented. The DNFSB covered a wide range of HLW program areas and was primarily interested in a total system/system analysis engineering approach to integrate the DOE HLW processing and disposal mission.

WINCO personnel also attended a meeting of the Westinghouse HLW System Government Owned Contractor Operated (GOCO) Integration Committee to complete the organizational phase of the committee work, define expectations for the remainder of FY-93, and develop a plan for arriving at a HLW summary integrated schedule. A draft charter was reviewed and marked up; contributions for eventual development of an integrated schedule were provided: updated information from all sites was provided; and a list of issues common to all sites was drafted, with further input from each site provided after the meeting.

A meeting of the Westinghouse GOCO Vitrification Committee was attended with the purpose of establishing a charter. list of issues, and planned 
sharing activities. The Vitrification Committee was formed out of the former HLW GOCO Integration Committee, along with committees on tank management. waste pretreatment, and LLW grout, as part of an expanding Westinghouse effort to integrate all of the HLW systems at each site. Discussion topics consisted of the waste acceptance process, including: the recently published documents on System Requirements and Product Specifications; interface between DOE-EM, DOE Office of Civilian Radioactive Waste Management (RW) and GOCO sites; status of Hanford Tank Waste Remediation Systems program; authorization for phased start-up of facilities: DOE Order compliance assessment; and DNFSB activities primarily at the SRS. Documents obtained at the meeting are being used to update draft waste acceptance requirements for Applied Technology tasks.

\section{National Programs}

A number of National efforts, separate from the Westinghouse GOCO committees, are being supported by the technology development program.

The first meeting of the Waste Form Barrier/Canister Team was held at the INEL on May 11 and 12, 1993. The meeting provided for a beneficial exchange of information concerning the management of DOE HLW/spent fuel and development of repository disposal. The discussions helped to identify some of the activities and data required to assess the development needed to reach a decision on a long-lived canister option. The Team is focusing on identifying EM activities that would be required to develop a waste form and canister for DOE HLW/spent fuels, while monitoring RW activities through ongoing technical reviews and future Team meetings.

WINCO hosted a facilitated meeting in which key personnel in the National Spent Nuclear Fuel (NSNF) program identified their needs and helped to establish an effective systems approach to managing the program. Following this meeting, a team, consisting of WINCO and EG\&G Idaho personnel, was established to provide the needed systems analysis support.

Under WINCO's Systems Analysis lead, a white paper was prepared to discuss the proposed systems analysis support from the INEL for the NSNF Program. The stakeholder involvement portion of the NSNF Management Program 
plan was also drafted and provided to the INEL NSNF committee. System diagrams representing the NSNF system and the Quality Assurance (QA) process were prepared and used at meetings of the Technology Integration and $Q A$ working groups in Salt Lake City. A decision flow chart and a summary of options matrix was developed to assist in a presentation of options concerning the applicability of spent nuclear fuel to RCRA. A prototype of the first module, "Existing Interim Storage," was started. This module will model the existing interim storage at the DOE sites, with data from the fuel and facilities database being incorporated into this model as required.

A meeting was attended involving the identification of items and activities important for meeting DOE-RW QA requirements, RW-0214, for HLW acceptance. As a result, an action plan was developed for preparing a white paper to describe the rationale and methodology used by each site for application of RW-0214. The experiences of other GOCO sites will be used by WINCO for developing the timely and cost-effective implementation of the necessary QA activities for waste acceptance.

Appl ied Technology attended the Yucca Mountain Site Characterization Project Waste Package Workshop in Las Vegas on September 20 to 23, 1993, to obtain supporting information needed for the Waste Form Barrier/Canister Team assessment of long-lived canisters for direct disposal of DOE HLW and spent nuclear fuel. Canister design concepts and materials that experts felt could retain complete containment for the range of $10,000 \mathrm{yr}$ in a Yucca Mt. repository environment were presented. Since very little testing has been completed, and more than five years of extensive materials testing will be required to provide the minimum accelerated test data, the participants recommended that the testing program be significantly expanded.

The Waste Form Canister/Barrier Team organized by WINCO met immediately after the Yucca Mt. Workshop. The primary goal of the Team is to arrive at an assessment of the long-lived canister concepts for direct disposal of DOE spent fuel and HLW so that a preliminary design concept could be used for a comparison with other processing options in current flowsheet studies. At the Team meeting, the waste package concepts presented at the previous workshop 
were thought to be adaptable to DOE HLW and spent fuels as a basis for comparison with the other processing flowsheets currently under evaluation. with several reservations. 
SODIUM-BEARING WASTE PROCESSING AND DECONTAMINATION DEVELOPMENT

\section{Decontamination Technologies}

The ICPP Decontamination Development Group has worked during FY.93 to evaluate and introduce new methods of decontamination to solve the problems of sodium and/or secondary waste generation. Decon Development has performed on-site demonstration/evaluation activities at the ICPP during $\mathrm{FY}-93$ on $\mathrm{CO}_{2}$ pellet blasting. liquid abrasive grit blasting and novel chemical flushing. Additional off-site testing sponsored by or in cooperation with the ICPP during FY.93 has resulted in the testing/evaluation of light ablation decontamination, liquid nitrogen blasting, $\mathrm{CO}_{2}$ snowflake blasting and improved concrete scabbling equipment.

\section{Simulated Contamination (SIMCON) Development}

During the 1980 's, a large number of samples were taken during chemical decontamination of process equipment at the ICPP. The data resulting from these samples was collected and recorded for the purpose of developing a better means of plant decontamination. By analyzing the data, some conclusions on the type, concentrations and isotopic ratios of ICPP contamination have been reached. This historical data was then incorporated into a usable and consistent method of comparing decon techniques ${ }^{3}$. As many of the decon techniques under examination were of a "mechanical" nature, the method had to simulate a metal surface which could be manipulated to give consistent decontamination comparisons between those techniques. An analytical method of detecting "before and after" results was desired, one which would yield relatively rapid, sensitive, reproducible results without high cost. In addition to these criteria, the method should be acceptable for transport to other sites for testing of non-WINCO owned equipment. $X$-ray Fluorescence (XRF) was chosen as the surface analysis technique. This method typically allows an upper range of 1000 ug and gives sensitivity to about 1 ug. This is an adequate range, allowing determination of a "single pass" decontamination factor (DF) of around 1000. A coupon size of $25 \mathrm{~mm}$ or about 1 inch, was chosen to fit the XRF cup used. These coupons were originally cut from a bar of 304 stainless, then polished on one side. A more cost effective method was developed of punching a 1 inch coupon of $1 / 4$ inch thick steel. 
Preliminary laboratory work concluded that a two element system would work best. in that each element could have interferences that would compound analysis. This was an acceptable compromise, as up to $90 \%$ of the radioactivity from historical data is in the form of Cs.137 and $\mathrm{Zr} \cdot 95$. One milligram quantities of nonradioactive cesium and zirconium salts were chosen for initial or "before" amounts. These concentrations of cesium and zirconium salts are not considered a hazardous shipment.

This method produced a simulated contamination coupon (SIMCON 1) of some utility. It was dubbed "loose" type contamination, because the contamination could be nearly completely rinsed from the surface. This was an effective comparison for some mechanical methods (i.e. $\mathrm{CO}_{2}$ blasting), because they focus mostly on removing loose contamination. Methods could be rated according to their effectiveness in removing SIMCON 1. Those methods which completely removed (< 1 ug out of possible $1000 \mathrm{ug}$ ) SIMCON 1 salts (1.e. abrasive grit jetting) needed an additional test, therefore development was begun on an additioned, more tenacious type of SIMCON. This was accomplished by oxidizing SIMCON 1 pellets at $700^{\circ} \mathrm{C}$ for 24 hours in a muffle fumace (this was chosen as a upper limit due to the increased volatility of cesium at this temperature). Coupons were removed from the oven, cooled, rinsed and brushed with a soft nylon bristle brush to remove a "scab-1ike" precipitate of iron oxide and the surrogate salts. SIMCON 2 prepared in this manner retained zirconium and cesium in the 100 to $200 \mathrm{ug}$ coupon range, yielding a tenacious residue of oxide and salts. This increased the retained surrogate materials into an acceptable range for methods intended to clean fixed contamination. These methods of preparing surrogates is similar to those previously prepared at the Rocky Flats and Savannah River DOE sites.

\section{$\mathrm{CO}_{2}$ Pellet Blasting Demonstration}

$\mathrm{A} \mathrm{CO}_{2}$ pellet blasting demonstration was performed at the ICPP decontamination facility. Environmental Controls Division (ECD), an outside contractor, was brought in to provide portable $\mathrm{CO}_{2}$ pellet blasting equipment and manpower to operate the equipment. WINCO engineers provided test plans, test specimens, and data evaluation ${ }^{4}$. The testing was performed in the Hot Shop of the New Waste Calcining Facility (NWCF). To operate the $\mathrm{CO}_{2}$ pellet 
blasting system, a large generator was brought on-site, along with liquid nitrogen. liquid carbon dioxide, and fuel supply tanks. All of the equipment except the nozzle and hose was located outside the Hot Shop. The Cold Jet blasting system used for this demonstration is a portable unit which means that the pelletizer, hopper, and air handling units were all separate components making it more maneuverable. These components all fit into a $15^{\prime}$ long $\times 8$ 'wide trailer.

$\mathrm{CO}_{2}$ pellet blasting is the use of compressed pellets of carbon dioxide snow. accelerated by a compressed air discharge, to perform surface cleaning. This is a non-destructive cleaning technique which is used extensively in food services, aerospace. and commercial nuclear industries. The $\mathrm{CO}_{2}$ pellet blasting system consists of liquid $\mathrm{CO}_{2}$ at 200.300 psig. which is transported through a hose to a pelletizer machine where rapid expansion of the liquid in the chamber converts the $\mathrm{CO}_{2}$ to a solid state of dry ice or snow. The snow is then compressed into pellets which are transported through a hose to a blasting nozzle. At the nozzle, the pellets are entrained in high pressure dir $(40.250 \mathrm{psig})$ and propelled from the nozzle onto the workpiece at 75.1000 feet per second. The $\mathrm{CO}_{2}$ pellet penetrates the coating. "mushrooms" under the coating as it strikes the substrate, and then sublimes causing the coating to fall off leaving only the coating as waste while the $\mathrm{CO}_{2}$ pellet returns to its natural state.

The testing showed that the $\mathrm{CO}_{2}$ pellet blasting system is effective for several everyday type cleaning operations. The system removed rust, tape. polyken wrap. and enamel paint from a variety of materials. Substrate removal was also investigated using wood and concrete. The system removed the substrate from wood, but was very limited on concrete. The only part of the substrate removed from the concrete was the top layer which consisted of cement and sand. After the top layer was removed and aggregate was exposed. the system was not effective. The $\mathrm{CO}_{2}$ pellet blasting system was used to decontaminate SIMCON pellets, these results are presented in Table 1. 
TABLE 1. CO2 Pellet Blasting SIMCON Results.

\begin{tabular}{|l|c|c|c|c|}
\hline Technology & $\begin{array}{l}\text { SIMCON I.Cs } * \\
\text { Removal }\end{array}$ & $\begin{array}{l}\text { SIMCON I-Zr } * \\
\text { Removal }\end{array}$ & $\begin{array}{l}\text { SIMCON:L Cs } * \\
\text { Removal }\end{array}$ & $\begin{array}{l}\text { SIMCON 2-Zr } * \\
\text { Removal }\end{array}$ \\
\hline $\begin{array}{l}\text { CO } \mathrm{O}_{2} \text { Pellet } \\
\text { Blasting }\end{array}$ & 91 & 92 & 63 & 78 \\
\hline
\end{tabular}

The second test showed this method of decontamination is highly effective for cleaning radioactively contaminated tools and materials, these results are in Table 2. This decontamination method is more effective on cleaning loose contamination than fixed. However, the system does remove significant amounts of fixed contamination. This testing confirmed what all of the reports and vendors have sald about the system being nondestructive. During this demonstration it should be noted that not only did the $\mathrm{CO}_{2}$ pellet blasting system work with a great deal of success but the system did not produce any secondary waste beyond the filters and enclosure. Installation of $\mathrm{CO}_{2}$ pellet blasting at the MUCF will not eliminate all of the chemical decon but will help reduce the amount of sodium waste that is being generated with the current decon techniques.

TABLE 2. Radioactive Tools Cleaned With CO2 Pellet Blasting At ICPP

\begin{tabular}{|l|l|l|l|l|}
\hline TEST PIECE & $\begin{array}{l}\text { FIXED } \\
\text { C/m }\end{array}$ & $\begin{array}{l}\text { FIXED } \\
\text { C/m }\end{array}$ & $\begin{array}{l}\text { SMEARABLE } \\
\mathrm{d} / \mathrm{m}\end{array}$ & $\begin{array}{l}\text { SMEARABLE } \\
\mathrm{d} / \mathrm{m}\end{array}$ \\
\hline Wire Brush & BEFORE & AFTER & BEFORE & AFTER \\
\hline Hammer & $1.200 \mathrm{~B} /$ gamma & $500 \mathrm{~B} / \mathrm{gamma}$ & $\begin{array}{l}937 \mathrm{~B} / \text { gamma } \\
14 \text { alpha }\end{array}$ & $\begin{array}{l}<200 \mathrm{~B} / \mathrm{gamma} \\
<10 \text { alpha }\end{array}$ \\
\hline Screw Driver & $450 \mathrm{~B} /$ gamma & $<100 \mathrm{~B} /$ gamma & $\begin{array}{l}800 \mathrm{~B} / \text { gamma } \\
40 \text { alpha }\end{array}$ & $\begin{array}{l}<200 \mathrm{~B} / \mathrm{gamma} \\
<10 \text { alpha }\end{array}$ \\
\hline $\begin{array}{l}\text { *Crit. } \\
\text { Barrier (top) }\end{array}$ & $22.000 \mathrm{~B} /$ gamma & $1.000 \mathrm{~B} /$ gamma & $\begin{array}{l}328 \mathrm{~B} / \text { gamma } \\
<10 \text { alpha }\end{array}$ & $\begin{array}{l}<200 \mathrm{~B} / \mathrm{gamma} \\
<10 \text { alpha }\end{array}$ \\
\hline
\end{tabular}

*Criticality barrier used for fuel storage spacing made of $304 L$ stainless steel. 


\section{Liquid Abrasive Grit Blasting}

Abrasive grit decontamination is accomplished by propelling a grit media against a contaminated surface. The abrasive action of the grit then strips the contaminant from the surface. There are various types of commercially avallable abrasive systems including dry blasting. which utilizes atr, or liquid blasting, which utilizes water, to propel the grit media. In most cases. liquid blasting is preferred because it reduces the amount of airborne contamination. Some advantages of wet abrasive decontamination are:

- High decontamination factors.

- Grit recycling.

- Abrasion depth variability (type of grit, system pressure).

- Liquid recirculation reduces the amount of secondary waste generated.

- Effectively removes smearable, fixed, alpha, beta and gamma contamination.

WINCO tested three different types of abrasives: plastic beads, glass beads and alumina oxide. To test the effectiveness of the different abrasive grits, a mockup of a glovebox type liquid abrasive grit blaster was designed and built ${ }^{5}$. The item to be cleaned was placed into the grit blaster through the plexiglas window. A recirulatory system was used to ensure uniform abrasive distribution throughout the slurry. The system used an air operated double diaphragm pump which was capable of pumping solids up to $1 / 16^{\text {" in }}$ diameter. The spray nozzle had two inlets, one for the slurry and one for the air. The air atomizes the abrasive slurry, this increases the aggressiveness of the system by reducing the cushioning effect the water has on the abrasive grit.

Plastic beads are the least aggressive of the three abrasives tested. Plastic beads are used to remove paint, oxide layers or rust without damaging the metal substrate. Glass beads are more aggressive than plastic beads but less aggressive than alumina oxide. Glass beads are also used to remove paint, oxide layers or rust with minimal damage to the metal substrate. Alumina oxide is an aggressive abrasive. It can remove metal substrate as well as paint, oxide layers or rust. 
During these tests. It was discovered that all three abrasives clean the SIMCON coupons in a different way. Plastics beads, being a relatively soft and mild abrasive. tend to "wipe" the contaminates off the surface. Glass beads, being a harder more aggressive abrasive, use the impact of the abrasive to remove the contaminates. Even though the glass beads are impacting the surface, surface photographs of the coupons at 50X and 500X show no adverse damage to the metal substrate. Due to the "peening" effect of the glass bead abrasive, the coupons had a shiny reflective surface after being cleaned. Alumina oxide, being the most aggressive abrasive tested. tends to grind away the contaminates. This was evident on both visual inspection of the coupons and with surface photographs. With some of the coupons, it was apparent some metal material had been removed. The exact amount of surface metal that was removed was not determined. This "grinding" effect may cause some of the contaminants to be trapped within the substrate if the item is not cleaned for a long enough period of time to allow the surface substrate to be removed.

TABLE 3. Liquid Abrasive Grit SIMCON Results.

\begin{tabular}{|l|l|l|l|l|}
\hline Technology & $\begin{array}{l}\text { SIMCON 1.Cs } * \\
\text { Removal }\end{array}$ & $\begin{array}{l}\text { SIMCON 1-Zr } \times \\
\text { Removal }\end{array}$ & $\begin{array}{l}\text { SIMCON 2.Cs } * \\
\text { Removal }\end{array}$ & $\begin{array}{l}\text { SIMCON 2.ZR } * \\
\text { Removal }\end{array}$ \\
\hline Plastic Grit & 99 & 99 & 72 & 98 \\
\hline Glass Beads & 100 & 100 & 94 & 100 \\
\hline Alumina Grit & 100 & 100 & 97 & 100 \\
\hline
\end{tabular}

\section{Liaht Ablation Decontamination}

WINCO and Ames Laboratory, a DOE facility operated by Iowa State University. Ames. Iowa, cooperated in the testing of light ablation decontamination for the removal of contaminated surface material from metal surfaces. The Ames approach to laser surface decontamination is to use high power. short pulsed. laser beams to decontaminate metals by removing contaminated surface layers (Pang, 1993). When metals, or other materials such as ceramics and plastics, are exposed to highly localized and intense photon sources, such as a focused laser beam, material is ablated from the 
surface into the surrounding atmosphere. This material can be collected via HEPA filtration of particulate-laden off-gases to prevent deposition back onto the surface or other nearby surfaces.

Three different lasers were available for use in cold testing of light ablation decontamination at Ames. These included:

A $\mathrm{CO}_{2}$ laser, continuous wave $(\mathrm{CW})$ at $10,600 \mathrm{~nm}, 2000$ watts.

A neodymium: yttrium aluminum garnet (Nd:YAG) rod laser which operates at a wavelength of $1064 \mathrm{~nm}$. the Nd:YAG unit could be operated in the "Q" switched ( 8 nanoseconds) or free running ( 30 microseconds) pulsed mode. $30 \mathrm{~Hz}, 190 \mathrm{mj}$ per pulse.

An eximer laser which operates at a wavelength of $248 \mathrm{~nm}, 28$ nanoseconds, $120 \mathrm{~Hz}, 350 \mathrm{mj}$ per pulse using a krypton/fluorine gas.

Testing of the $\mathrm{CO}_{2}$ laser was limited to only two SIMCON coupons due to the excessive melting of metal coupons that was experienced. The actual cleaning that was recorded on the SIMCON coupons was surprisingly high. However, significant heat transmission (and accompanying surface melting) from the action of the $\mathrm{Cw} \mathrm{CO}_{2}$ laser on the metal surface was noted. Vaporized metal material was sprayed to adjacent areas: a shield gas was therefore required to protect lens surface. It is theorized that some portion of the SIMCON contaminant was vaporized and moved beyond the surface of the coupon during the ablation. An average of two SIMCON tests is shown in Table 4.

TABLE 4, Light Ablation SIMCON Results.

\begin{tabular}{|l|l|l|l|l|}
\hline Technology & $\begin{array}{l}\text { SIMCON 1-Cs * } \\
\text { Removal }\end{array}$ & $\begin{array}{l}\text { SIMCON 1-Zr } * \\
\text { Removal }\end{array}$ & $\begin{array}{l}\text { SIMCON 2-Cs * } \\
\text { Removal }\end{array}$ & $\begin{array}{l}\text { SIMCON 2-ZR * } \\
\text { Removal }\end{array}$ \\
\hline $\mathrm{CO}_{2} \mathrm{CW}$ laser & 97 & 86 & $\star$ & $\star$ \\
\hline ND:YAG laser & 98 & 99 & 75 & 99 \\
\hline Excimer laser & 99 & 98 & 77 & 99 \\
\hline
\end{tabular}


The Q-switched Nd:YAG laser performed with very high decontamination efficiencies. This laser is not as high average power as the $\mathrm{CW} \mathrm{CO}_{2}$ or the excimer, but has a very high power density $\left(109 \mathrm{~W} / \mathrm{cm}^{2}\right)$ due to the short ( 8 nanosecond) pulse length. The beam was focused to a $1 \mathrm{~cm}$ line via a cylindrical lens. Three passes were required to complete the cleaning of a 1 " coupon. Overall average decontamination is very high (Table 4). The Nd:YAG laser has the added benefit of a wavelength which enables the use of fiber optic delivery. Problems have been experienced in using this capability because of the extreme power density. Currently fiber technology has not achieved reliable transmission of the high power. Nd:YAG electro-optic short pulses. Additional development has been contracted between WINCO and Ames to investigate the fiber optic transmission of acousto-optic Nd:YAG lasers. This kind of $\mathrm{cw} / \mathrm{pulsed} \mathrm{Q}$-switched laser has demonstrated high power fiber optic transmission with nearly as short (100 - 150 ns range) pulses with a higher repetition rate than the electro-optic variety.

Excimer lasers can achieve the high power density over a larger area ( 3 $\mathrm{cm}$ line) at a higher pulse rate. This relates to much higher decon rate, as about 4 times more pulses can be applied in three times as large a line than the electro-optic Q-switched Nd:YAG. This relates to the cleaning of the 1" SIMCON disks in about 20 seconds. This type of laser, though more powerful for ablation work. has drawbacks in the areas of supply gas, maintenance and fiber optic application. A hazardous gas, krypton/fluorine, is the fill gas for the laser. therefore inventory and disposal of hazardous materials must be factored into its operation. The cavity of this laser must be cleaned and the laser maintained much more often than the Nd:YAG. Finally, because of the very low wavelength $(248 \mathrm{~nm})$ no fiber optic delivery system can be obtained for the $\mathrm{Kr} / \mathrm{F}$ eximer system.

\section{Miscellaneous SIMCON Tests}

Water Flushing. Water flushing of systems is a common and typically very effective method of cleaning. This can range from soaking in water, to jetting streams of water over the equipment surface. An advantage of water flushing is the virtual absence of additional chemicals, water is quite easily handled in most waste systems. Another advantage is that water is a good solvent, particularly for loose cesium salt contamination. However, many 
other types of contaminants are insoluble in water flushes, resulting in large volumes of wet waste, which can be a disadvantage.

TABLE 5, Miscellaneous SIMCON Results.

\begin{tabular}{||l|l|l|l|l||}
\hline Technology & $\begin{array}{l}\text { SIMCON 1-CS } * \\
\text { Removal }\end{array}$ & $\begin{array}{l}\text { SIMCON 1-Zr } * \\
\text { Removal }\end{array}$ & $\begin{array}{l}\text { SIMCON 2-Cs } \\
\text { Removal }\end{array}$ & $\begin{array}{l}\text { SIMCON 2-ZR * } \\
\text { Removal }\end{array}$ \\
\hline Water rinse & 100 & 99 & $*$ & $*$ \\
\hline Ultrasonic & 100 & 100 & 70 & 88 \\
\hline $\begin{array}{l}\text { Strippable } \\
\text { coatings }\end{array}$ & 87 & 66 & $*$ & $*$ \\
\hline $\begin{array}{l}\text { Cerric } \\
\text { Nitrate }\end{array}$ & 100 & 100 & 61 & 77 \\
\hline $\begin{array}{l}\text { Cyrogenic } \\
\text { tool }\end{array}$ & 99 & 99 & 76 & 95 \\
\hline CO, Snowflake & 83 & 94 & 26 & 78 \\
\hline
\end{tabular}

* Not appropriate for SIMCON 2, see note in particular section.

SIMCON 1 pellets were flushed with a running stream of deionized water to remove "loose" type materials. The coupons were held in one hand and the spray of a squeeze bottle was directed over their surface. This was a very effective method of removing SIMCON 1 (Tabie 5). SIMCON 2 pellets are flushed in the same manner as SIMCON 1 above during their preparation, therefore no additional tests were conducted.

Ultrasonic Cleaning. Ultrasonic cleaning uses a high frequency oscillator to cause strong vibrations to impinge on equipment surfaces. This in turn may cause physical degradation of the surface and cavitation of entrapped gases (air bubbles) in the solution, resulting in an overail scouring effect. This is a highly effective method of cleaning and is used routinely in industrial settings. For equipment that is removable this method is an effective improvement to chemical soaking. However, in a remote, radioactive area where large vessels and piping are encountered, it is not practical. Several hundred ultrasonic transducers would be required to accomplish this type of cleaning on a several thousand gallon vessel. 
SIMCON 1 and 2 were cleaned in a ultrasonic bath for about one hour at ambient temperature. Coupons were put in water in a poly bottle, then placed into the ultrasonic bath. SIMCON 1 pellets were cleaned to virtually $100 \%$. SIMCON 2 were substantially less affected (Table 5). Given sufficient power. ultrasonic cleaning should be able to remove SIMCON 2, potentially even destroying the metal surface.

Strippable Coatings. Some loose contamination can be sealed in a polymeric coating (like a paint) and removed as the coating is removed. Two such coalings are ALARA $1146^{\mathrm{TM}}$ (Carboline Co.) and TLC ${ }^{\mathrm{TM}}$ Stripcoat (Bartlett Nuclear (o.). They are only weakly affixed to equipment, so they can typically be peeled off the surface to which they are applied. The "paints" are typically formulated to contain no "OSHA hazardous" materials. They are considered environmentally benign.

In the case of ALARA $1146^{\mathrm{TM}}$, it is easiest to remove if it is sprayed onto the surface to achieve a coating thickness of about 1 mil. If applied by brush or other method, it tends to be very difficult to peel. $\mathrm{TLC}^{\mathrm{TM}}$ Stripcoat however. may be brushed, sprayed, or even poured on a surface and peels very easily. Some operating experience at the ICPP using ALARA $1146^{\mathrm{TM}}$ has shown that this type of coating is difficult to use in the reprocessing environment, and returned little benefit, removing only loosely held contamination. TLC ${ }^{\mathrm{TM}}$ Stripcoat was offered by the manufacturer as an easier to remove coating, and was tested using SIMCON 1 to determine its effectiveness on the "loose" contamination equivalent (Table 5).

"Stripcoating", as it is called, tends to be reserved for loose contamination situations and for preparing a surface prior to a contamination generating task. If one knows that a particular area is going to become contaminated, it is common to apply a strippable coating prior to that task, then apply a second coat after the task to create a contamination "sandwich". A new type of stripcoating is being marketed by Westinghouse Nuclear Services that can be used underwater in refueling pools, giving substantial contamination protection in that activity.

Ceric (IV) Nitrate. A novel method of chemical decontamination using ceric(IV)nitrate has been developed by engineers at Battelle Pacific Northwest 
Laboratories (PNL), Richland, Washington. This method is a controlled milling of stainless steel surface using the strong oxidizing effect of the $\mathrm{Ce}(\mathrm{IV})$ ion. which is highly corrosive. A substantial amount of development work was conducted for West Valley Nuclear Services by PNL during the late 1980 's for use of this method for decontaminating glass canisters. The corrosion potential of the ceric(IV)nitrate waste may be reduced with the addition of a small amount of hydrogen peroxide to produce a non-corrosive cereus (III) nitrate.

A coupon of SIMCON 1 and one of SIMCON 2 were cleaned during a visit to PNL in August of 1993. The SIMCON 1 coupon was cleaned using $0.5 \mathrm{M}$ ceric nitrate, $2.0 \mathrm{M}$ nitric acid at $70^{\circ} \mathrm{C}$, for about $1 \mathrm{~min}$, and rinsed off with water. This produced a clean, shiny appearance and removed all contaminants to below detectable levels. The SIMCON 2 coupon was cleaned using the same concentration of solution at $80^{\circ} \mathrm{C}$ for a total of 13 minutes. The coupon did not have the shiny, clean appearance, and required much brushing and rinsing. This process achieved a reduction of $77 \%$ of the zirconium and $61 \%$ of the cesium (Table 5). These are fairly significant reductions using a non-RCRA hazardous chemical flush. Waste can be easily adjusted to a noncorrosive state.

Cryogenic Cutting Tool. The Cryogenic Cutting Tool is a technique being developed by EG\&G Idaho for cutting and cleaning various materials with zero added waste. A very high pressure jet of liquid nitrogen and $\mathrm{CO}_{2}$ crystals is directed on a work piece like an "abrasive blaster". Unlike typical abrasive blasters using a grit, there is no secondary waste generation with this tool.

Coupons of SIMCON 1 and SIMCON 2 were tested using the Cryogenic Cutting Tool. These results are not a true test of the effectiveness of this device, as it is only in the operating prototype stage. Also, low value coupons were used for the SIMCON 2 (about $20 \%$ of typical values). Given these caveats, the results were fairly consistent with those we found with the $\mathrm{CO}_{2}$ pellet blasting. On average, 99\% of the SIMCON 1 was removed, and 95\% of the zirconium and 76\% cesium were removed from the SIMCON 2 (Table 5). With optimization and proper restoring control of the cutting nozzle, exceptional results could be achieved with this device. 
$\mathrm{CO}_{2}$ Snowflake. The $\mathrm{CO}_{2}$ Snowflake blaster uses compressed carbon dioxide $\left(\mathrm{CO}_{2}\right)$ to produce a solid $\mathrm{CO}_{2}$ "snow" under pressure for a gentle cleaning action. This machine was developed by Hughes Aircraft Co. to clean the high quality optic systems of sophisticated, large mirror telescopes. It is currently under evaluation for use in robotics cleaning. The device is a handheld "gun-like" trigger mechanism that is easily manipulated and requires only a tank of pure carbon dioxide as a supply.

SIMCON 1 and SIMCON 2 coupons were cleaned with the snowflake gun. Results of the testing were not entirely conclusive, as they were somewhat erratic. Again, on average, 94 and 84 percent of the zirconium and cesium, respectively, were removed from SIMCON 1, and about 70 and 26 percent of the zirconium and cesium, respectively, were removed from SIMCON 2 (Table 5). Overal1, not an insignificant cleaning technique, given the extremely small investment, utility needs and resultant secondary waste. Probably slightly more effective than compressed air, and only marginally more difficult.

\section{Sodium-Bearing Waste Technologies}

A letter was issued describing the baseline case for treating SBW; that is, calcining SBW with a blend of cold ANN. The baseline case will be refined as additional or more accurate information becomes available, and will serve as the reference method for comparison of alternative treatment methods.

Seven SBW processing methods were identified in meeting one of the milestones for FY-1992. Since that time, research proposals have also been received from Universities and commercial industry for other SBW processing alternatives. To make optimum use of the resources available, each of the alternative methods were qualitatively evaluated to determine which have the greatest potential for success with respect to the evaluation criteria established. In addition, it was determined who could most efficiently and effectively perform the research. The following processes will be investigated at ICPP: (1) sodium removal by extraction with crown ether and/or polymerized crown ether; (2) sodium removal and recovery by electrodialysis/electrohydrolysis; (3) sodium removal by freeze crystallization: and (4) cesium, strontium and sodium removal by sorbents. Actual freeze crystallization testing at the ICPP is only a possibility. 
The following outside contracts in support of the alternative SBW treatment program were awarded: (1) freeze crystallization testing by the FTC acquisition company in Raleigh. NC: (2) Supported liquid membrane testing by the University of Utah: and (3) Ion exchange/crown ether testing for radionuclide removal by the University of Idaho.

Rotary driers were evaluated as a possible treatment option for the SBW. Two articles on the subject of rotary kiln vitrification were located and reviewed. Liquid wastes can not only be dried in the kiln, but wastes also can be melted and fed directly into a disposal container. It was determined that rotary kiln driers do not appear to have a significant benefit to our SBW alternative program.

The radionuclide concentrations that are known for the existing SBW were compared against limits that are used to classify waste for near-surface disposal. Four waste form scenarios were evaluated: calcine, grout, glassceramic, and glass. The radionuclides were Sr-90, Tc-99, I-129, Cs-137. Np237. Pu (al1), and Am-241. The calculations showed that Pu-238 and Am-241 will exceed the release limits for all waste forms. Sr-90 and Cs-137 will meet $C l$ ass $C$ requirements but will not meet $C$ lass $A$ for all waste forms. Some other $\mathrm{Pu}$ isotopes will contribute to exceeding the limit. The maximum value for Tc-99 was only 0.02 of the limit. This provides valuable information for application of separation technologies as to which constituents are of most concern and the removal efficiencies that must be achieved.

A report was issued identifying candidate technologies for SBW treatment, completing a DOE program plan milestone. The six candidate technologies for SBW treatment are: (1) freeze crystallization to remove sodium nitrate $\left(\mathrm{NaNO}_{3}\right)$; (2) crown ether separation of sodium or cesium and strontium; (3) electrohydrolysis for $\mathrm{NaNO}_{3}$ salt splitting and chemical recycle: (4) solution denitrating and neutralization by addition of formic acid or electrochemical reduction; (5) inorganic sorbent ion exchange and sorption for cesium and strontium removal; and (6) the transuranic extraction process (TRUEX) for removing transuranics from the SBW treatment technologies. 
A spreadsheet program was completed to calculate the volume and composition of calcine produced by calcining 1 to 3 arbitrary streams containing the major species of the SBW and typical additives. This program will be used to compute the volume of waste produced by calcining either high activity waste (HAW) or LLW streams. Along with this work, cost estimates of the various SBW processing options (TRUEX, freeze crystallization, crown ether) were made for comparison to the current baseline process (cold ANN calcination).

Preliminary material balances and cost estimates for four candidate SBW treatment technologies were completed. The candidates are: (1) decontamination of the SBW using TRUEX to separate the transuranics, followed with ion-exchange to separate Cs. Sr, and heavy metals; (2) freeze crystallization to remove most of the sodium prior to calcination of the concentrated radioactive and hazardous constituents; (3) crown ether separation of the sodium followed by calcination of the sodium-depleted stream; and (4) dissolution of existing alumina and zirconia calcine to dilute the SBW during calcination.

Laboratory scoping studies necessary to investigate possible future SBW processing technologies were initiated as scheduled. These studies include experiments to determine the sodium removal effectiveness of 7 different types of crown ethers via extraction in 2 different diluents. A run plan to test ion-exchange sorbents for removing both $\mathrm{Cs}$ and $\mathrm{Sr}$ in simulated SBW streams was also prepared. Inorganic sorbents to be tested include zirconium and titanium phosphates. Additional scoping tests involving both electrohydrolysis and denitrations were also initiated. Electrohydrolysis may be capable of dividing radionuclide depleted SBW streams into reusable sodium hydroxide $(\mathrm{NaOH})$ and nitric acid $\left(\mathrm{HNO}_{3}\right)$. Denitration using formic acid, steam reforming, rotary kiln treatment or electrochemical techniques may be necessary to ensure a suitable grout form for LLW streams generated from SBW treatment.

All planned SBW treatment experimental scoping studies are in progress or are set to begin at the first of August. The first series of crown ether laboratory tests was completed, and new quantities of promising crown ethers were ordered for further testing. A run plan for precipitation/neutralization 
experiments using $\mathrm{NaOH}$ to precipitate polyvalent cations from the SBW was issued. Laboratory equipment to begin testing electrohydrolysis, chemical denitration, and ion-exchange using inorganic sorbents was assembled.

The Alternative Technology Development subsection conducted laboratory scoping tests to evaluate SBW treatment alternatives. At the $77 \%$ completion point results were as follows:

- $\quad$ Conducted the first set of crown ether studies to screen 7 different crown ethers and 3 diluent extraction systems. Three crown ethers exhibited promising results for separating sodium from the waste simulant. Additional quantities of these crown ethers were ordered for testing.

Selected nine different inorganic ion-exchange materials as candidates for removing cesium and strontium from SBW. The first set of tests revealed that 4 of these materials have modest capacities for cesium removal under highly acidic conditions.

Completed SBW denitration/neutralization scoping tests. The experiments revealed that the SBW simulant can be neutralized to a $\mathrm{pH}$ of 1.0 by the addition of formic acid. Further addition of formic acid appears to be ineffective in reducing the acidity. The reaction kinetics are best at higher temperatures $\left(T \geq 45^{\circ} \mathrm{C}\right)$.

- Electrohydrolysis scoping study preliminary results demonstrate that $\mathrm{NaNO}_{3}$ can be effectively split into $\mathrm{NaOH}$ and $\mathrm{HNO}_{3}$ using a bipolar membrane. This process may be applicable in providing a pure sodium source from SBW for future decontamination.

Based on the recent DOE/Navy/State of Idaho agreement, the SBW Technology Program now has new commitments as well as additional funding drivers. The commitments involve presenting potential technology options to the Governor's office by mid-November 1993, and recommending a single option by December 31, 1995. 
Various waste treatment experts from the National Laboratories and State of Idaho Universities were brought together in late September to review the choices of technologies being investigated and the development approach being taken for SBW treatment. The peer review members recommended that development efforts continue in precipitation, freeze crystallization, and TRUEX. This information was transmitted to the State of Idaho as requested by DOE-ID.

\section{Selection Criteria}

A technical selection criteria matrix was developed for the SBW separation technology alternatives. The criteria were categorized by those that can be determined through: (1) FY-1993 experimental studies. (2) further detailed experimental investigation in FY-1994, (3) pilot plant studies, and (4) literature and/or engineering calculations. The criteria were expanded to include more specific and quantifiable variables that can be measured or determined through laboratory and pilot plant experiments. These criteria will guide testing plans and help to ensure more standardization of test objectives where applicable.

In addition to the evaluation criteria and schedule that were previously prepared, simplified and detailed flow diagrams, a decision tree, and a matrix tree were developed for technology acceptance criteria.

SBW processing development work will develop separations technologies that could generate each type of waste (i.e. low activity, transuranic (TRU), high activity, hazardous). However, the criteria for classifying the types of waste and for long-term disposal are not clearly defined. Therefore, a waste definition and criteria committee was formed with representatives from the various Spent Fuels and Waste Management Program sections. The primary purpose of the committee is to initially discern the definition of and requirements for disposal of transuranic, low-level, and mixed wastes. These definitions will ultimately determine the separation efficiencies required to meet the criteria for disposal.

The Alternative Technologies Development Subsection participated in two days of meetings to compare and rank the final set of SBW process technologies evaluation criteria. The Kepner-Tregoe decision analysis process was used for 
paired comparison and ranking. An alternative scoring method was used which avoids giving criteria of lesser importance a zero weighting factor. Even though some criteria are less important when compared to the others, they still need to be considered.

A report on weighting factors for the SBW process technology evaluation criteria was issued, satisfying a DOE program plan milestone two months ahead of schedule.

\section{Waste Simulant}

A suitable simulant of the tank farm waste to be used in cold experimental tests was identified and prepared. The ranges of concentrations that are expected for various streams were evaluated by Analytical Chemistry personnel to ensure that the capabilities were in place to measure the constituents at the sensitivities required. Preparation techniques of the simulant were developed to prevent precipitation during makeup. A 1-liter batch of the simulant was prepared to verify the recipe and makeup procedure. and to provide samples for verification of analytical methods.

A test plan was developed for testing the SBW simulant shipping containers before shipping the simulant to subcontractors. The test involved heating the solution in the containers for 14 days and then performing a drop test with the container filled with water to check for container integrity. The test was successfully completed, and waste simulant was transported to the University of Idaho for scoping studies to evaluate the removal of cesium from SBW using crown ether solvent extraction.

A 150 gallon batch of simulant was sent to the freeze crystallization subcontractor in Raleigh. North Carolina. A low-nitrate, sodium-bearing simulant was also developed for the second set of sorption experiments. A small amount of this low nitrate simulant was shipped to SNL where sorbent studies are being performed. 


\section{Electrohydrolysis}

Electrodialysis (ED) involves anionic and cationic membrane separation. while electrohydrolysis (EH) involves these plus a bipolar membrane for the splitting of water into $\mathrm{H}^{+}$and $\mathrm{OH}$. Water splitting enhances the membrane separation by increasing the process efficiency, but the feed must have very low calcium concentrations to prevent membrane fouling. Types of membranes. called fluorinated cross-linked polymers, were identified for testing as the anionic and cationic membranes. A membrane manufactured by WIS Technologies was identified for testing as the EH bipolar membrane.

A test plan was issued for performing EH scoping studies and requisitions were submitted for EH equipment. $E H$ is being investigated to determine the feasibility of splitting $\mathrm{NaNO}_{3}$ from various SBW processing technologies into $\mathrm{NaOH}$ and $\mathrm{HNO}$. These streams could then be recycled for use as decontaminating agents, neutralizing agents, or dissolvents, depending on process needs.

Scoping tests with the EH system were completed. Test results show that $E H$ is an effective means of producing acid and base solutions from the product of either freeze crystallization or crown ether extraction of sodium. Test results also showed that the electrical current efficiency, which indicates the amount of current flowing through the unit that is actually used for acid and base production, decreases with increased operating current and is not affected by system temperature or flow rate. The power consumption of the unit increases with decreasing temperature and increasing operating current, and is not affected by flow rate. A report summarizing these findings was also completed.

\section{Denitration}

Denitration scoping studies use formic acid for the purpose of denitrating and neutralizing SBW to assess any effects on process efficiencies and effectiveness. Equipment was procured for the tests and instrument calibrations were performed. A nitrate detection probe will be used for the purpose of determining the extent of reaction, rather than pulling samples for laboratory analyses. 
The denitration/neutralization scoping tests involving incremental addition of formic acid to a $100 \mathrm{ml}$ batch of sodium-bearing simulant at $30^{\circ} \mathrm{C}$. $45^{\circ} \mathrm{C}$ and $60^{\circ} \mathrm{C}$ were performed. The rate of off.gas evolution (oxides of litrogen $\left(\mathrm{NO}_{x}\right)$ and $\mathrm{CO}_{2}$ ) and nitrate concentration were progressively monitored. Additionally, samples were collected at the conclusion of each test to measure the final nitrate and formate concentration. Gas samples were also collected for gas chromatographic analyses. Scoping study test results indicate that denitration with formic acid is not a particularly effective process for SBW as it is only possible to neutralize the waste to a $\mathrm{pH}$ of approximately 1.0. This may be beneficial for freeze crystallization; however, for ton exchange technologies. It may be necessary to increase the $\mathrm{pH}$ to approximately 4 for effective separation of Cs and Sr. The primary disadvantages of formic acid denitration are that large amounts of gas and heat are evolved rapidly if an excessive amount of formic acid accumulates in concentrated $\mathrm{HNO}_{3}$ prior to reacting.

\section{Ereeze Crystallization}

An announcement in the CBD resulted in 5 entities indicating interest in performing freeze crystallization (FC) studies on SBW. A statement of work requirements was prepared to submit to the companies, along with the request for proposal. Westinghouse Hanford has ownership of some FC equipment, that was used for studies performed by Freeze Technologies Corporation. Inc. (FTC). which they were willing to excess to WINCO. Therefore, the process of transferring ownership of this equipment to WINCO was completed.

Mass balance calculations were performed for the FC flowsheet to be recommended for incorporation into the overall strategic spent fuel and waste management processing scheme. With respect to the SBW feed, the respective final waste volumes and mass reduction ratios (based on glass for HLW and grout for LLW) are 18:1 and 9:1 for HLW, and 11:1 and 8:1 for LLW. Waste volume reductions resulting from the SBW treatment options, compared to calcination with cold ANN, range from $7: 1$ to $13: 1$, depending on the achievable mole fraction of sodium in the calcine. 
The FC subcontract started in mid July and was scheduled to be completed within 6 months. The experimental pilot plant was assembled during September and October, and testing will begin in November 1993. As stated earller. 150 gallons of SBW simulant was prepared at the ICPP and shipped to the subcontractor for these tests.

FTC. the company contracted by WINCO to perform initial pilot plant scoping studies for SBW volume reduction, completed a Test Plan document. including: (1) computer modeling results for operation of the proposed system (mass and energy balances): (2) their defined chemistry for the simulated SBW provided by WINCO; and (3) test plans for upcoming pilot plant operation. FTC personnel also made required modifications to their pilot plant for the run.

Two trips were made to FTC in Raleigh. NC, to discuss the FC test plans. and to analyze the PP. The system and its operation do not appear to be complex. The system consists of four major components (crystallizer, salt growth/separator vessel. ice wash column, and salt wash column) and two major variable operating parameters (refrigerant flow rate, and residence time). PP testing was scheduled to begin in November. FTC was optimistic about testing results, expecting verification of the computer modeling projections of approximately $70 x$ removal of both water and $\mathrm{NaNO}_{3}$ from the simulated SBW. Potential further $\mathrm{NaNO}_{3}$ removal from the concentrated waste solution effluent. may be possible, but at the expense of having the $\mathrm{NaNO}_{3}$ "contaminated" with $\mathrm{HNO}_{3}$.

\section{Ion Exchange}

Inorganic sorbents to be investigated for ion exchange removal of sodium, cesium, and strontium were identified. Specifications and requisitions were prepared and submitted to procure various compounds of titanium and zirconium phosphates, copper haxacyanoferrate, polyantimonic acid, and ammonium molybdophosphate (AMP). Contacts at ORNL suggested that optimum cesium and strontium removal might be achieved using mixtures of these two sorbents. An additional sorbent, phosphotungstic acid, was found to be available at the ICPP. therefore, a cost savings was realized. 
Based on data reported in technical journals, 9 different inorganic ion. exchange materials were selected as candidates for removing cesium and strontium from SBW. The first set of tests revealed that 4 of these materials have good selectivities and affinities for cesium under highly acidic conditions.

The ammonium molybdophosphate sorbents will require immobilization. Tests for immobilizing the AMP and determining capacities are scheduled for 1994. Testing of crystalline silicotitanates (CST) was conducted at the SNL. Hot treatability testing is scheduled for the spring and summer of 1994 using actual SBW with CST and immobilized AMP.

\section{Crown Ether}

A test plan was prepared and issued for scoping studies to be performed to assess the feasibility of using crown ethers for removing sodium from the SBW. Literature investigations were performed to assure appropriate selection of the diluent for the crown ether.

The waste simulant to be treated was prepared. an organic satellite accumulation area was designated for storing the used organics, and a flammable storage cabinet was procured for this purpose. Permission was also obtained from the Operations and Environment. Safety and Health (ES\&H) Departments to dispose of the non-hazardous organic waste to the calciner as fuel.

The first set of crown ether studies was designed to screen 7 different crown ethers and 3 diluent extraction systems. As a result of these studies Applied Technology identified a crown ether and diluent capable of selectively extracting Na from simulated SBW. The second order of this crown ether was received for continued experimentation. Crown ether stripping experimentation was performed for the seven crown ethers used in the initial extraction portion of the scoping study, and duplicate extractions were performed for the one successful crown ether system after it was eluted of the solute. Sample analyses were received for these subsequent stripping and duplication tests and will be evaluated via use of a spreadsheet. 
Sol-Gel

A study on experimental tests for immobilizing sodium waste solutions by sol-gel synthesis was performed. The study investigated the historical development of the sol-gel process, the importance of geochemical distribution of elements, and potential benefits resulting from application of the sol-gel process for SBW containment in glass or glass-ceramic phases.

A study on incorporation of sodium in the aluminosilicate gei and its retention at higher temperatures was performed. The study indicated potential advantages of sol-gel technology for direct immobilization of ICPP SBW, and recommended continued evaluation of the sol-gel technology as a SBW immobilization option.

A review and assessment of two new potential SBW treatment alternatives was made. The sol-gel waste solidification process was determined to be too immature to pursue as a candidate for processing the ICPP SBW. A technical presentation and discussion on the sodium alumina electrolyte process was given at the ICPP by Glen Hollenberg of Battelle Pacific Northwest Laboratories (PNL). While this process shows promise for cleanly separating sodium from the wastes, the SBW would require several steps of waste conditioning. This technology is also early in the development stage and will not be pursued by WINCO Alternative Technologies Development at this time.

\section{Precipitation}

Tests were performed to determine the extent of cation removal by precipitation as SBW simulant is neutralized by $\mathrm{NaOH}$ addition. Effective precipitation does not occur until solution pH is increased above 3 . With a solution $\mathrm{pH}$ of 3.7, over $90 \%$ of the dissolved solids will precipitate. However, an increase of total waste volume by approximately $50 x$ is necessary to accomplish this $\mathrm{pH}$ level.

\section{Pilot Plants}

Potential locations and/or applicability of existing equipment for performing cold pilot plant studies of alternative SBW treatment methods were 
identified. New centrifugal contactors or the existing solvent extraction PP in the high bay of CPP.620 will potentially meet the needs of three pilot plant studies: (1) sodium removal by crown ether solvent extraction: (2) actinide and strontium removal using the TRUEX and SrEX processes respectively: and (3) removal of cesium and strontium by sorption media.

Several obsolete pilot plants (PEW evaporator. FDP dissolver, airlift mock-up) were removed from the CPP.637 pilot plant laboratories. The removal frees up necessary space for the new test facilities required for the calcine immobilization and spent fuel program.

An Idaho Air Quality Permitting Applicability Questionnaire was completed and submitted to the ES\&H Department. This information initiates the environmental documentation process for the subsystem and pilot plant facilities to be designed in the future to support the SBW process development program. The questionnaire will be evaluated by the ES\&H Department to determine the applicability of permits to construct or permits to operate these facilities.

Changes to the Hazardous Chemical Waste Handling Facility (HCWHNF) Part B permit were approved by the State of Idaho. The changes address treatment with ANN. The Systems Operability (SO) test procedure for the HCWHNF was completed, and review comment resolution is in progress. The safety analysis report will not be issued until the SO tests are complete.

System operability testing of individual components on the Acid Fractionator Pilot Plant (AFPP) was completed. Leak testing of the AFPP was completed, and the SO test procedure was finalized and approved. Integrated SO testing and operator training were started. There have been problems with the steam regulators and other equipment. The defective equipment is being replaced or repaired. Much discussion was held on the vessel off-gas (VOG) tie-in. which has escalated from a $\$ 1000$ job to a job costing over $\$ 21 \mathrm{~K}$, because this is a tie-in to a plant utilities system.

The run report for the AFPP runs completed in August was issued. Based on experience with the test runs, the AFPP unit is capable of processing low concentration acid at feed rates of 100 to $130 \mathrm{ml} / \mathrm{min}$. The pilot plant unit 
will provide the technical support where needed to keep the Liquid Effluent Treatment and Disposal facility operations successful.

The run plan was issued and equipment installed to flush pilot-plant calcine from a buried, abandoned VOG line underneath CPP.620 as part of the Comprehensive Environmental Response, Compensation, and Liability Act (CERCLA) remedial action for this site being conducted by the Site Remediation section of the ES\&H Department. The purpose of the line flush is to remove hazardous materials. primarily cadmium, so the line can be abandoned in place with no further actions required. The line flush was started on October 1, 1993 and took about 3 days.

\section{NOx Abatement}

A meeting was held to discuss the flammability and explosivity of ammonia $\left(\mathrm{NH}_{3}\right)$ and ammonium nitrate $\left(\mathrm{NH}_{4} \mathrm{NO}_{3}\right)$. Based on published reference sources and $\mathrm{NH}_{3}$ and $\mathrm{NH}_{4} \mathrm{NO}_{3}$ production plant experience, the possibility of a boiling liquid expanding vapor explosion or sustained flame, due to a leak in the $\mathrm{NO}_{x}$ Abatement Facility $\mathrm{NH}_{3}$ storage tank, was judged to be extremely low. $\mathrm{HNO}_{3}$ fumes and $\mathrm{NH}_{3}$ react to form solid or aqueous $\mathrm{NH}_{4} \mathrm{NO}_{3}$ and do not involve a kinetic mechanism that produces a chain reaction, necessary for an explosion. Therefore, $\mathrm{NH}_{3}$ and $\mathrm{HNO}_{3}$ will not detonate.

The $\mathrm{NO}_{\mathrm{x}}$ Abatement Installation Plan for the State of Idaho was revised to implement the change in mission that has occurred since it was issued in March 1992. The revision el iminates references to future fuel reprocessing activities, and was submitted to the ES\&H Department for transmittal to DOE-ID and then to the State of Idaho. The Permit to Construct/Prevention of Significant Deterioration (PTC/PSD) requires that the installation plan be used and submitted to the State of Idaho annually.

A letter was issued to the ES\&H Department expressing the need to acquire timely LDR relief needed for the $\mathrm{NO}_{x}$ Abatement pilot plant to operate during the NWCF campaign scheduled for December 15, 1992, through Apri1 30. 1993. Since the $\mathrm{NO}_{\mathrm{x}}$ Abatement pilot plant cannot be operated unless the NWCF is operating, additional delays to LDR relief could jeopardize the ability of the development program to meet its objectives. If the objectives are not 
met, the quality of technical input to the design of the full-scale project will be compromised. A message was received from the ES\&H Department that the LDR issues for running the $\mathrm{NO}_{x}$ Abatement pilot plant were resolved.

Revisions to the operating instructions and run plan for the $\mathrm{NO}_{\mathrm{x}}$ Abatement pilot plant were completed and issued. A sample plan was also prepared and issued for performing the toxicity characteristic leaching procedure (TCLP) analysis on the selective catalytic reduction (SCR) and Pt catalyst used in the $\mathrm{NO}_{x}$ abatement PP.

A statistical analysis of NWCF $\mathrm{NO}_{\mathrm{x}}$ emissions revealed that $\mathrm{NO}_{\mathrm{x}}$ emissions are primarily dependent on the total nitrate feed rate and oxygen feed rate.

The $\mathrm{NO}_{\mathrm{x}}$ Abatement pilot plant was started up and operated for the purpose of addressing a Tiger Team corrective action to characterize the temperature dependency of nitrous oxide formation. It was determined that, in general. nitrous oxide formation decreases with increasing operating temperatures.

Completion of Tiger Team Corrective Action Plan AIR/BMPF-1.AP01, Milestone 2, "Perform Ammonia Oxidation Tests, " was accomplished through a research contract with the Brigham Young University (BYU) Catalysis Laboratory. BYU's research extended beyond the scope of work stated in the corrective action plan, investigating alternative catalysts in addition to the platinum catalyst for reducing ammonia slip from as high as 500 ppm to less than $10 \mathrm{ppm}$.

Cost savings of up to $\$ 50,000$ are achievable as a result of reducing the design basis temperature limit for the $\mathrm{NO}_{x}$ Abatement Facility. At a lower temperature, off-gas blower costs can be reduced by approximately 20\%. Justification for a lower design basis off-gas temperature was obtained by calculating the temperature dependent dissociation constant for ammonium nitrate.

Due to changes in program direction, it has been decided that the $\mathrm{NO}_{x}$ Abatement effort is no longer needed. 


\section{HEPA Filter Leaching}

A report was issued presenting the calculated radionuclide, toxic metal, and $\mathrm{HNO}_{3}$ emissions from typical operation of the proposed NWCF High Efficiency Particulate Air (HEPA) Filter Leach System. These emissions are being used by Environmental Permitting personnel as the source terms for dispersion modeling as well as for air permitting.

Tests were performed to investigate filter gasket decomposition as a cause for Atmospheric Protection System (APS) HEPA filter plugging. The tests indicated that burning gasket material would plug the APS HEPA filters. however the gasket material would have to be heated above $430^{\circ} \mathrm{C}$ to create filter-plugging smoke.

\section{Tank Farm}

A list was prepared identifying the tank farm constituents that needed to be measured to adequately characterize the SBW for process development purposes. The list was discussed with Analytical Chemistry personnel to determine the sensitivity of analyses of specific constituents in the presence of others, as well as the development of new analytical methods. The tanks were scheduled to be sampled during the NWCF campaign.

The sampling and characterization of the tank farm waste solutions were initiated earlier than planned to effectively use the NWCF downtime. The additional sampling and analyses to support the SBW process development program were identified and submitted to the Operations Department. Samples were obtained from WM-180 prior to a VOG outage, which will temporarily delay further sampling.

A database was prepared for recording tank farm waste composition analyses and federal regulatory limits for the various components. A program was developed for comparing the waste characteristics to the regulatory criteria for LLW. This information will be used to determine the level of effectiveness required by the SBW treatment technology to be employed. Two of 
the waste tanks (WM-180 and WM-181) were sampled and characterized. However, since the waste tanks cannot be sampled during NWCF operations (except the specific tank being processed), samples of the remaining SBW tanks will not be available for characterization by the end of July. Therefore, a change request was submitted to extend the characterization milestone to the end of September 1993. In addition, tank composition histories are being evaluated to assess the need for sampling all of the tanks.

Applied Technology determined the current volumes, chemical compositions, and radionuclide activities for the SBW tanks (WM-180, WM-181, $W M-183$. WM-184, $W M-185$, and $W M-186)$. This characterization was done by sampling and analysis (WM-180 and WM-181), and by accounting for al1 significant material transfers into and out of the other tanks since the last characterization performed in 1989 . This updated characterization is documented in WINCO letter BLB-02-93/ and BDMN-09-93, and completes the FY. 1993 program milestone to characterize the composition of the SBW in the tank farm.

WINCO completed the compilation of tank farm compositional history from 1962 to 1993, and transmitted a report to DOE-ID. This information had been requested by the State of Idaho. The tank farm sump data compilation that was also requested by the State of Idaho is continuing, and the report will be ready for internal review in late September.

To simulate the effect of an acidic waste leak from a pipe inside a cell wa11. concrete compatibility studies to determine the effects of reinforcing bar and concrete cold joints on acidic liquid waste migration are being conducted. After 21 days, the 4 molar $\mathrm{HNO}_{3}$ solution (being used to simulate hazardous waste) had not leaked out of either the cold joint test cylinders or the reinforcing bar test cylinders.

Preliminary new waste characterization data for design of the new tank farm were provided for incorporation into the design criteria. The chemical composition for corrosion purposes was based on the composition of tanks WM187 and WM-188, with some corrosion enhancers such as chloride added. The radiochemical content was double that in WM-182. Additional data will be provided on the chemical, radiochemical and physical properties of the solids. 
Treated water is a large source of the SBW generated at ICPP. Therefore, treated water usage was evaluated and two possible options were identified for reducing sodium in this application. The first is to connect the demineralized water headers to the treated water headers and use demineralized water rather than treated water. The second alternative would be to replace the water softening unit with a reverse osmosis unit that would not require sodium for treatment.

Applied Technology issued a letter with flowsheet calculations for calcining cold ANN/WM-102 (2nd/3rd Cycle waste) blends at the NWCF. These blends will operate similarly to the ANN/WM-182 (aluminum) blends that were used for short periods ( 3 to 10 batches at a time) at the NWCF in Apri1. May and July. 


\section{Waste Acceptance/Waste Form}

A draft screening and ranking system of technology acceptance criteria was developed to evaluate potential process options for immobilizing ICPP HLW calcine at minimum volume. The screening/ranking system will be used to format a matrix and decision tree for assessing information needs for the process evaluations.

A draft outline for preliminary waste acceptance specifications emphasizing the glass-ceramic waste form was submitted to the WINCO Waste Acceptance Criteria Committee. This draft outline supports the committee's efforts to establish a Preliminary Waste Acceptance Criteria (PWAC) for waste at the ICPP, and represents progress toward meeting the section milestone of issuing a draft specification by September 1993.

Four calcine types were sent to the INEL Research Center (IRC) for Scanning Electron Microscope (SEM) sample preparation and characterization. The calcine types sent include zirconia, alumina, fluorinel/sodium, and aluminum/sodium. Calcine particle homogeneity was determined by analyzing specific points across the diameter of a large ( $>400$ micron), medium (100-200 micron), and small (<100 micron) particle. Changes in homogeneity will impact the reaction rates to convert calcine to a glass-ceramic form during hot isostatic pressing. Composition change with respect to particle size was determined by analyzing several large, medium. and small particles and determining the average composition of each element in the particle.

Knowledge of calcine physical and chemical properties are required to design the various calcine immobilization process unit operations. Calcine solids physical properties used to design equipment such as transport systems and storage and reaction vessels important to the calcine immobilization program have been identified. The information provided in this study will be used to outline the specifications for establishing an in-house calcine flow characterization laboratory and to procure the instrumentation for the laboratory. 
An estimate of the total number of glass-ceramic or glass canisters that would be produced from current HLW inventories (both liquid Na waste and calcines) was made. Depending on the assumptions, between 3288 (immobilization of calcine only) and 4126 (immobilization of calcine and liquid $\mathrm{Na}$ waste) glass-ceramic canisters or 7821 and 9821 glass canisters would produced in order to immobilize all known ICPP HLW.

A preliminary flow diagram to recycle pilot plant calcines used in future blending and grinding studies was prepared. Used pilot plant calcines could be redissolved using fresh acid or concentrated calcine condensate and recalcined. Through use of this recycle concept the savings in hazardous waste disposal costs would be significant. The flow diagram is being refined and a cost evaluation will be completed to determine the feasibility of this concept.

A draft report summarizing the most cost effective way to produce cold pilot plant calcine for immobilization process development was issued for review. Three alternatives are discussed:

- Refurbishment and operation of the existing $30 \mathrm{~cm}$ calcine PP.

- Design, construction and operation of a new pilot-scale $(70 \mathrm{~cm})$ calciner.

- Obtaining surrogate calcine from an outside vendor.

The analysis indicates that the most cost effective option is to obtain cold calcine from an outside vendor.

Battelle Pacific Northwest Laboratories were toured to obtain information for ultra-thin preparation of glass, glass-ceramic, and calcine waste forms. Ultra-thin samples are required for use in certain solid state analytical techniques, including transition electrom microscopy, superprobe analysis, and optical techniques. Procedures for ultra-thin sample preparation were acquired. 
The ultimate goal in developing options to immobilize ICPP HLW is to convert calcined HLW to a glass-ceramic form that will meet regulatory disposal criteria. Past emphasis has been on identifying compositions that result in chemically-durable products, as measured by standard leaching tests. Experiments that define the effects of key process parameters on desirable product characteristics will provide vital information for defining the control required on these parameters in the full-scale glass-ceramic process. These parameters include hot isostatic pressing (HIPing) time. HIPing temperature, calcine particle size, amount of metal additive, and waste loading. Glass-ceramic formulations of potentially high durability (Formulations 4870-2A1 [aluminum metal additive] and 4270-5Ti [titanium metal additive]) were selected for characterization in this study. Response surface methodology was identified as the most practical approach for investigating the effects of the five selected process parameters, on the desirable characteristics of products of these formulations. Completing the study will require 29 HIPing runs, using a systematic combination of process parameters within operable limits to form the glass-ceramic products. The results of this study will be empirical models that produce response surfaces defining glass-ceramic product durability characteristics as functions of the selected process parameters and their interactions.

The ceramic composition spread sheet program (CERCOMP)was used to define four additive formulations for immobilizing alumina calcine. The relevant ternary phase diagram $\left(\mathrm{CaO}, \mathrm{Al}_{2} \mathrm{O}_{3}, \mathrm{SiO}_{2}\right)$ compositions were incorporated in the computer program in order to accomplish this. Solid state analyses of the products indicates that the estimated glass phase compositions are near the mullite $\left(3 \mathrm{Al}_{2} \mathrm{O}_{3}-2 \mathrm{SiO}_{2}\right)$ composition. The estimated additive composition for densifying alumina calcine is 77.5 wt\% silica $\left(\mathrm{SiO}_{2}\right), 16.0 \mathrm{wt} \%$ sodium carbonate $\left(\mathrm{Na}_{2} \mathrm{CO}_{3}\right)$, and 6.5 wt\% boron oxide $\left(\mathrm{B}_{2} \mathrm{O}_{3}\right)$. Reactant $\mathrm{Ca}$ metal would be added at 0.3 wt\% also (based on CERCOMP calculations). Four glass-ceramic alumina waste formulations were prepared by HIPing at $1050^{\circ} \mathrm{C}, 20,000$ psi for 4 hours. All of the resulting waste forms were very hard, 8.9 on the Mohs hardness scale compared to 4-5 Mohs for other ICPP glass-ceramic formulations and 10 Mohs for diamond. Samples of each were prepared for durability (1each) testing through use of the MCC-1 static leach test and phase analysis by SEM examination. 
The results of X-ray diffraction analysis, electron microprobe analysis, optical microscopy, leachant analysis, and model calculations were compiled for the waste form development report titled, Hot Isostatically Pressed Aluminosilicate Glass-Ceramic with Natural Crystalline Analogues for Immobilizing the Calcined High Level Nuclear Waste at the Idaho Chemical Processing Plant. ${ }^{7}$ The results of this work are valuable in determining the potential of certain durable and highly loaded glass-ceramic waste forms for immobilizing ICPP HLW. This report describes testing of 25 waste forms as a function of changes in the formulation. The elemental and total mass loss leach rates for several waste forms were below $1 \mathrm{~g} / \mathrm{m}^{2}$-day when subjected to the MCC.1 static leach test.

A contract was placed with Claytec Corporation of Sandy, Utah to perform initial scoping studies to sinter pilot plant fluorinel-sodium calcine by a patented $\mathrm{Claytec}$ process. This process is considered an alternative waste form with high loading for immobilizing ICPP HLW. Four clay waste forms were prepared by Claytec and evaluated as alternatives to HIPed glass-ceramics. The waste forms were prepared by heating a mixture of fluorinel-sodium calcine 70.90 wtz. and clay 30.10 wtz at $1400^{\circ} \mathrm{C}$ for 6 hours in a cylindrical graphite mold. The density of the clay forms varied from 2.9 to $3.1 \mathrm{~g} / \mathrm{cc}$. Scanning electron microscope (SEM) examination revealed that the forms consisted of crystalline phases in glassy matrix. The four clay-based calcine monolith waste forms are being subjected to 14-day MCC-1 leach test. The chemical composition the clays is: aluminum oxide $\left(\mathrm{Al}_{2} \mathrm{O}_{3}\right) 15.5$ wt\% $\mathrm{SiO}_{2} 75.6$ wt\% , sodium oxide $\left(\mathrm{Na}_{2} \mathrm{O}\right) 1.8 \mathrm{wt} \%$, and magnesium oxide (MgO) $0.8 \mathrm{wt} \%$. The four waste forms are currently being subjected to the 14-day MCC-1 static leach testing procedure.

Glass phase compositions of the Claytech Corporation Clay 41 and Clay 42 waste forms (Clay 41:70 wt\% fluorinel-sodium calcine, 30 wt\% clay: Clay 42:80 wt\% fluorinel-sodium calcine and 20 wt\% clay) were calculated using SEM techniques. The glass phase compositions for the Clay waste forms lie within the phase compatibility triangle for $\mathrm{SiO}_{2}$, alpha-Wollastonite $\left(\mathrm{CaSiO}_{3}\right)$ and anorthite $\left(\mathrm{CaAl}_{2} \mathrm{Si}_{2} \mathrm{O}_{8}\right)$. The 14-day total mass loss rate responses of these waste forms to the 14 -day MCC- 1 static leach test in deionized water at $90^{\circ} \mathrm{C}$ for 70 and $80 \mathrm{wt} \%$ calcine load clay waste forms are 0.45 and $0.44 \mathrm{~g} / \mathrm{m}^{2}$. day, respectively. 
An external WINCO report titled. Ialc.Silicon Glass-Ceramic Waste Forms For Immobilization of High-Level Calcined Waste. ${ }^{8}$ was completed. It describes the evaluation of talc-silicon glass-ceramic waste forms as candidates for immobilization of the HLW stored on-site at the ICPP. The waste forms were characterized for density, chemical durability, and glass and crystalline phase compositions. The results indicate improved density and chemical durability as the silicon content is increased.

Discussions were held with representations from Minerals Technologies Corporation for evaluating the possibility of a cooperative research agreement for the development of a Talc-Si based glass-ceramic waste form for immobilizing calcine. WINCO has received talc (hydrous magnesium silicate) from Minerals Technologies for waste form development activities. The Talc.Si glass-ceramic waste forms were prepared by HIPing a mixture of talc. Si, and simulated fluorinel-sodium calcine. The waste forms were characterized for density, chemical durability, crystalline phases and microstructure. The talc shows promise as a relatively inexpensive waste form additive that has potential for reducing immobilization costs for ICPP HLW when compared to other formulations.

A versatility study based on response surface methodology is being performed to determine the ability of three glass-ceramic forms for immobilizing $\mathrm{Fl} / \mathrm{Na}$ calcine to retain desired properties when HIPed under a range of conditions that can be expected in full scale processing. All required twenty-nine HIP runs of the study were completed. One hundred and sixteen glass-ceramic products were prepared from these runs, twenty-nine for each of the four formulations subjected to the test. Density measurements and the 14-day MCC-1 static leach tests were performed on eight products. The leach results indicate that products of two titanium metal based Formulation 42-Fluorinel/Na calcine preparations have normalized elemental leachabilities of less than $1 \mathrm{~g} / \mathrm{m}^{2} /$ day for all elements investigated (A1, B, Ca, Cd, Cr, Cs, $\mathrm{K}, \mathrm{Na}, \mathrm{Si}, \mathrm{Sr}$ ). No products of the other glass-ceramic formulations formed to date have all elements leaching at less than this rate.

Calcine Immobilization section personnel completed a versatility test on three $\mathrm{Fl} / \mathrm{Na}$ glass-ceramic waste formulations. The three formulations tested 
were combinations of $\mathrm{Fl} / \mathrm{Na}$ calcine mixed with an alumina-silica, titanium. silica or phosphorous pentoxide-silica additive. Results indicate that products of the titanium-silica formulation have superior mass loss properties compared to the other formulations when subjected to the 14-day MCC.1 static leach test.

Two contracts for performing waste form analyses were awarded. One contract will allow WINCO personnel to use the University of Houston's Superprobe for solid state analysis of waste form candidates. The other contract will provide the services of a specialized scientist, who will conduct microstructure analyses on candidate waste forms.

Electron microprobe analysis for chemical composition and microstructure was completed on 16 ICPP HLW waste form candidates at the Texas Center for Superconductivity. University of Houston (WINCO subcontract). Data were gathered through application of energy dispersive elemental $x$-ray spectra, wave length dispersive quantitative analysis, and microstructural analysis at both low and high magnifications. The purpose of this ongoing detailed study using the electron microprobe is to explore and develop the technical base for waste form durability through understanding the phase chemistry, frit versus calcine interactions, elemental concentrations in defect structures such as grain boundaries and inclusions, and the overall microstructure.

An electron superprobe procurement specification was prepared and issued. The superprobe is a state-of-the-art electronic-optical instrument used for solid state quantitative chemical analysis and will be used to characterize the structure and composition of ICPP HLW forms. The procurement package includes a flow property indicizer, surface area, pore size, density, and crush strength analyzers. The superprobe and analyzers will provide the calcine and waste form physical and chemical property information required to model immobilization process unit operations.

Four possible candidate locations for the installation of the Calcine Immobilization super probe were identified. The super probe provides high resolution analysis of material microstructure when controlled ambient conditions (vibration, temperature, and magnetic fields) can be achieved where it is installed. The four candidate locations can supply these conditions 
with the addition of engineered controls, such as improved heating. ventilation, and air conditioning (HVAC) systems. The conditions for each location were evaluated and the CPP.637 Radioassay Room was identified as the best location. A scope of work for upgrading this area to accommodate the microscope was proposed, based on information obtained from the super probe vendors and through tours of other electron microscope facilities.

A run plan for developing experimental on-line analysis of calcine and/or calcine/frit mixtures by Inductively Coupled Plasma Atomic Emission Spectroscopy (ICPAES) was issued. The experiments will determine the feasibility of analyzing these materials by powdering the calcine and elutriating the fines into a gas stream that passes directly into a plasma torch. If successful, this system would eliminate the lengthy discrete sample dissolution step(s) associated with the ICPAES method and allow use of on-1ine process instrumentation for the calcine immobilization process.

Calcine Immobilization personnel applied a Plackett-Burman screening design to determine the dominant processing parameters in the stabilization of Run $64(\mathrm{Zr} / \mathrm{Na})$ calcine product. Fluidized bed stabilization of calcines is being investigated. Operating temperature is by far the most significant parameter. Bed size was also a significant parameter.

The 1993 Statistical Applications Plan for the Calcine Immobilization Section was completed. Applications to process development and laboratory research activities by personnel in these sections include diagnostic techniques such as two-way ANOVA and standard descriptive statistics. Experimental design techniques being applied by personnel to development activities include the Plackett-Burman screening design and response surface methodology.

Effects of calcine particle size and HIPing time on chemical durability of glass-ceramic waste form (Series 48: 70 wtK LTWM-1-90 calcine, 28 wtK $\mathrm{SiO}_{2}$. 2 wtx Al metal) were investigated. Calcine particle sizes used in this study were $180 \mu \mathrm{m}$ ( $80 \mathrm{mesh}$ ) and $600 \mu \mathrm{m}$ (as calcined particle size), and the HIPing times were 4 and 24 hours. Fourteen and 28-day MCC.1 leach tests were conducted on monolith samples, and chemical analyses of leachates were performed for elemental mass losses. The results indicate that the total mass 
loss rates and elemental leach rates for A1, B, Ca, Cs, Cr, Cd, Si, Na, K, Sr and $Z r$ are all less than $1 \mathrm{~g} / \mathrm{m}^{2}$.day. This information supports Series 48 as a potential waste form candidate for immobilization of the fluorinel-sodium calcine.

A letter report was written describing the properties and preparation of the isolated glass phase of 4870-2Al glass-ceramic waste form. The glass phase (composition determined from scanning electron microscopy) from the waste form was prepared from reagents to simulate the glass phase oxide composition then vitrified at $1400^{\circ} \mathrm{C}$. The isolated glass phase had leaching properties for glass forming elements (AI, B, K, Na, Si) similar to those of the glass-ceramic. The formation of this representative isolated glass phase is significant, because it provides a feasibility basis for developing procedures for preparing glass-ceramic phases in isolation. Solid state. durability and leaching mechanism studies on isolated phases may be required in the qualification testing of ICPP multi-phase waste forms for repository disposal.

\section{Alternative Technologies}

A letter report was issued describing the status and technical feasibility of pyrochemical treatment of ICPP HLW calcine. This report meets a key DOE milestone for the pyrochemical development program. It will also serve as a basis for directing future work on the pyrochemical treatment of ICPP calcine.

WINCO personnel visited LLNL on December 17 and LANL on December 18 to discuss potential collaborative efforts in developing pyrochemical treatment methods for ICPP HLW calcine. WINCO personnel also toured pyrochemical development facilities and looked at equipment that may be relevant for performing upcoming tests, such as direct reduction and other molten salt separation work.

Design of equipment for remote calcine volatility tests using NWCF calcine was completed, and operation of the equipment was simulated in the Remote Mockup Facility before installation in the RAL hot cell. This equipment will be used to determine the extent of cesium and technetium 
volatilization from actual calcine. The volatilization process is proposed as a calcine pretreatment scheme for either pyrochemical or aqueous processing of calcine.

Volatilization test results with LTWM-1-88 calcine indicated 70 percent of the cesium volatilized at $900^{\circ} \mathrm{C}$ in 5 hours with a $200 \mathrm{cc} / \mathrm{min}$ argon purge rate. This compares with 36 percent cesium volatilization at $800^{\circ} \mathrm{C}$ and equal time and purge rates. In both tests, cadmium and chromium volatilization was less than one percent. These results indicate it may be possible to selectively remove cesium from calcine by the use of an optimum purge rate and temperature.

Calcine volatiles testing has indicated only 10 to 12 percent recovery of volatilized cesium. In order to determine whether volatilized cesium reacts with the ceramic weighing boat used, a nickel weighing boat was tested. Heat treatment of the boat at $900^{\circ} \mathrm{C}$ for 5 hours under a argon purge resulted in no degradation and a very small ( 0.006 wt percent) weight loss. Reaction of cesium or cesium compounds with the nickel is not expected. Results of these volatility tests indicate no uranium volatilization has occurred.

Experiments were conducted in order to determine cesium and iodine decontamination factors (DFs) from ICPP pilot plant calcine by ${ }^{137} \mathrm{CS}$ volatilization. Run $20(\mathrm{~A} 1 / \mathrm{Na})$ and $17(\mathrm{Zr} / \mathrm{Na})$ calcines were spiked with ${ }^{137} \mathrm{Cs}$ and ${ }^{131} \mathrm{I}$. Each calcine sample was heated at a specific temperature $(700,800$ or $900^{\circ} \mathrm{C}$ ) for a specific time $(1,2$, or 3 hours). This allowed DFs to be determined as a function of temperature and time. After heating, the samples were recounted. The test was repeated with increased cesium and iodine masses (by spiking the calcine with nonradioactive species of these elements). Results from these tests show that: (1) all the iodine was removed after 1 hour at $700^{\circ} \mathrm{C}$, and (2) cesium did not volatilize readily at $700^{\circ} \mathrm{C}$. Only after heating at least 3 hours at $800^{\circ} \mathrm{C}$ or higher did significant cesium volatility occur.

A run plan describing experimental tests to determine the effectiveness of a halide volatility process to remove inert constituents of ICPP calcine was issued. The proposed process involves reacting the calcine with chlorine 
gas to convert metal oxides to metal chlorides. This volatility process will allow a $25.90 \%$ reduction in HLW volume requiring disposal.

The Calcine Immobilization and Analytical Sections completed preliminary calcine chlorination experiments with alumina and zirconia pilot-plant calcines. The results showed a mass reduction of $85 \mathrm{wt} \%$ for the alumina calcine, and due to the complex chemistry, a 14 wt\% increase for the zirconia calcine. The gaseous phase collected for both calcines (proposed low-level radioactive waste stream) showed no trace of cesium or strontium, indicating a preliminary separation between radioactive and non-radioactive calcine components.

A report was issued on the potential application of chemical vapor deposition to waste immobilization. The report concluded that this technology could provide a versatile option for immobilization of calcine and other wastes. The proposed process could prove less costly than other options by eliminating some processing steps and simplifying others.

A peer review of Cobalt Dicarbollide technology was attended in Tucson. AZ. The purpose of the peer review was to render a professional judgement regarding the future pursuit of cobalt dicarbollide technology by DOE. This technology was presented by a delegation of 9 Russian scientists and engineers. The Russian delegation is very interested in applying this technology to acidic wastes (i.e. ICPP SBW and dissolved calcine). The results of the peer review indicate that several issues would need to be resolved before this technology could be used in the U.S.

Valeriy Romanovskiy of the V. G. Khlopin Radium Institute of St. Petersburg, Russia, visited the ICPP to assess the potential for collaborative work. The Khlopin Institute is performing radionuclide partitioning tests on simulated Idaho acidic waste. Future tests using Russian technology and reagents on actual waste will be performed at the ICPP in FY.94.

An actinide/fission product separation literature search was completed, fulfilling an FY-93 Calcine Immobilization program milestone. This search included literature on liquid/liquid extraction, sorption, supported liquid membrane, ion exchange, and analytical techniques. These articles and reports 
will be used as reference material in identifying which processes will be tested in the laboratory.

A six-member team of internationally recognized nuclear separations experts was assembled to review HLW minimization technologies applicable to ICPP calcine. The objectives of the meeting were to: (1) identify the possible technologies available for separating actinides and fission products from dissolved calcine, (2) evaluate the technologies based on technical feasibility and recommend separation technologies for testing, (3) develop a laboratory strategy for testing the recommended technologies, and (4) formulate a document summarizing the proceedings of the meeting. The document will form a basis for testing efforts as well as provide information to WINCO Management and DOE. The first three objectives were accomplished during the meeting and a rough draft of the summary document was written. The team made use of the ISU Simplot Decision Center, which allowed a fully-interactive and documented meeting format.

An experimental run plan was issued and testing of dissolution flowsheets for ICPP calcine was initiated. Many separation technologies anticipated for future testing require a stable aqueous feed solution prepared from the dissolution of major calcine types. These experiments will be used to determine optimal conditions (e.g. time, temperature, acid and calcine concentrations, etc.) for dissolution of each major calcine type.

Furthermore, the stability of the resulting aqueous systems with regard to reprecipitation or compositional changes over time must be evaluated.

Calcine Immobilization completed development of a flowsheet and material balance for the separation of actinides and fission products from dissolved calcine.

Tests were performed on zirconia (pilot plant run 74) and Alumina (pilot plant run 77) calcines to determine the quantitative amounts of cesium and strontium leached from calcine using hot water. Variables under consideration in the tests are water temperature, time, leach rate and calcine particle size. Results of the tests are pending analytical analysis. 
Preliminary scoping tests were completed on water leaching of simulated pilot plant calcine. Preliminary tests indicate that effective water leaching is not dependent on time or particle size. There is a slight dependence on temperature, although further temperature studies are recommended. Test results show an average of $75 \%$ of the cesium leaches from simulated zirconia calcine.

Dissolved calcine feed stability test data obtained show that no solids have formed at $25^{\circ} \mathrm{C}$ and $70^{\circ} \mathrm{C}$ in solutions made from dissolving $\mathrm{Zr}$ calcine in 5 and $8 \mathrm{M} \mathrm{HNO}_{3}$ after 30 days. However, a precipitation is seen after 1 day in

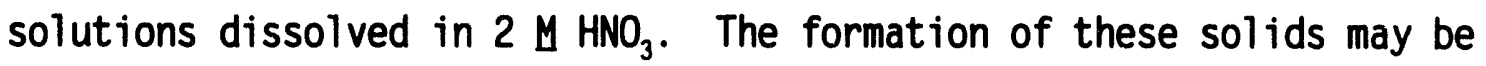
prevented or slowed down by: (1) the addition of small amounts of boron (as boric acid) to the dissolved calcine, (2) blending the dissolved calcine with an aluminum based calcine, or (3) simply diluting the dissolved calcine with water.

A presentation titled "The Use of Ascorbic Acid as a Plutonium Reducing Agent in the Tri-butyl Phosphate and Hexone Uranium Solvent Extraction Process" was presented at the $19^{\text {th }}$ Actinide Separations Conference held May 17-20, 1993 in Richland, Washington. In this paper, ascorbic acid was investigated as an alternative to using the ferrous ion for plutonium reduction. Ascorbic acid proved to be more effective at reducing plutonium than the ferrous ion, is more resistant to oxidation by $\mathrm{HNO}_{3}$, does not contribute to the formation of solids in the extraction process, and will result in a reduction in the volume of HLW. The presentation was well received and was used in the development of a novel analytical procedure at ICPP. Ascorbic Acid is also proposed for use in the Hanford "Clean Option" waste treatment flowsheet as a reducing agent.

Preliminary calcine dissolution tests were completed for 5 major calcine types in $8 \mathrm{M} \mathrm{HNO}_{3}$ at $90.100^{\circ} \mathrm{C}$. The results indicate most major calcine types are largely soluble in concentrated $\mathrm{HNO}_{3}$ media. The exception is alumina calcine that contains predominately a-Al.

Statistically designed dissolution experiments with Run \#17 ( $\mathrm{Zr} / \mathrm{Na})$ and \#20 (Al/Na) pilot plant calcine were completed. These experiments examined the effects of calcine concentration (grams calcine per $\mathrm{ml}$ acid), acid 
concentration, temperature, and time on the weight percent of calcine dissolved. Under the test conditions between 40 and $96 \mathrm{wt} . \%$ of the calcine was dissolved. The upper limit of solubility, $96 \mathrm{wt} . \%$, was observed for hot $(90-1000) 8 \mathrm{M} \mathrm{HNO}_{3}$, a two hour dissolution time and a calcine concentration of $1 \mathrm{~g} / 50 \mathrm{ml}$. The experimental data indicates the importance of the variables (or effects) decreases in the order: Calcine Conc. > Temp. > Acid Conc. > Time.

WINCO issued an interim report that presented the results of experiments on dissolution of pilot plant calcines. It is possible to achieve $90 \mathrm{wt} . \%$ dissolution of most pilot plant calcines with $5 \mathrm{M} \mathrm{HNO}_{3}$, an acid/calcine ratio of $10 \mathrm{ml} / \mathrm{g}$. temperatures of around $90^{\circ} \mathrm{C}$, and dissolution time of 30 minutes. These results will be utilized in future dissolution tests and in process flowsheet development work.

An aqueous based flowsheet was proposed as a potential technology for processing spent fuel, SBW, and calcine. The process would utilize solvent extraction and ion exchange to remove uranium, transuranics, strontium, cesium and technetium. The proposed process utilizes well developed technologies that could be implemented into a single facility producing one HLW and one LLW waste form. Approximate waste volumes from a liquid feed of 100 liters would be 150 liters of low-level grout and 6 liters HLW (assuming glass).

Calcine Immobilization performed a set of TRUEX extraction scoping studies with ${ }^{241} \mathrm{Am}$, ${ }^{238} \mathrm{Pu}$, and ${ }^{239} \mathrm{~Np}$ tracers in SBW simulant. The purpose was to examine the extractability of the individual radionuclides from the matrix of the SBW simulant into the TRUEX solvent. Based on preliminary results, actinide removal from SBW via the TRUEX process appears feasible.

Calcine Immobilization performed scoping experiments to test cementitious fixation of simulated ICPP wastes. The wastes tested were: (1) a mixture of synthetic calcines chosen to represent average ICPP calcine, and (2) a combination of the same calcine simulant with caustic ash similar to that which could be made from the tank farm's liquid SBW by steam reformation. Finished concrete specimens were made at both normal room temperature with atmospheric pressure curing, and under elevated temperature $\left(250^{\circ} \mathrm{C}\right)$ with 15,000 psi HIP curing conditions. 
A purchase order for 12-stages of centrifugal contactors was placed with ORNL. ORNL will provide the design, administer the fabrication contract, provide quality control and perform SO testing of the contactors. The 12 . stages of new contactors, as well as 4-stages of existing contactors, will be installed in CPP.637. The centrifugal contactors will be used to perform flowsheet testing for the removal of actinides and fission products from aqueous waste streams.

ORNL has awarded fabrication of 3 four-pack centrifugal contractors to Oak Ridge Tool-Engineering Company. The scheduled delivery date to ORNL is September. 1993. ORNL will perform SO testing on the contractors and ship them to WINCO in September or October. 1993.

\section{Process Development}

Site visits were made to hot isostatic press (HIP) equipment vendors and HIP materials processing experts to obtain information applicable to the glass-ceramic development effort. The vendor visits included BDM, National Forge, and ASEA, Inc. The vendors expressed confidence that HIPing equipment can be successfully designed and built for use in the glass-ceramic process. Procurement information was also obtained for laboratory and pilot-scale HIPing equipment from National Forge and ASEA. BDM presented information on a computer model and in-situ HIP measurement techniques that may be useful for HIP container design and scale-up.

A subcontract was prepared to obtain outside expertise in the area of hot isostatic pressing (HIPing). This subcontract will consist of three main tasks: (1) computer model of the can dimensional changes observed during HIPing, (2) in-situ measurements of can dimensional changes during HIPing, and (3) HIP cycle optimization for small and large-scale cans. The information obtained from the subcontract will be used for HIP can scale-up and final product geometry control.

A recommendation to use the concept of a volume reduction factor (VRF) to describe the process performance of HIP canisters with respect to the HLW volume savings afforded by the glass-ceramic process was prepared. A base case VRF of 2.6 was calculated for the glass-ceramic process compared to the 
glass process for calcine HLW. This is equivalent to $2.023 \mathrm{~g}$ of calcine per glass-ceramic canister compared to $774 \mathrm{~g}$ of calcine per glass canister assuming equal size canisters. The use of a 2.0 " outside diameter $\times 4.0$ " high bellow-type canister for future glass-ceramic laboratory development is also recommended. Materials required to build twenty-five HIP canisters of this size were received, and fabrication of the canisters completed. Testing of the 25 bellows canisters will be completed once adequate pilot plant calcine stores are identified.

In order to reduce the number of hot isostatic press experiments required to develop a full-scale canister and to provide near term equipinent to perform intermediate and full-scale HIP canister experiments, two RFPs were issued. The first RFP requests design and computer modeling services to assist with canister scale-up and HIP cycle optimization. The model will be verified by existing experimental HIP canister results and real-time HIP canister deformation data. The second RFP requests the near term use of 6 " to 18" outside diameter HIP equipment and vendor expertise to establish an intermediate-scale HIP canister design baseline.

A major procurement board meeting was held for design and procurement of an intermediate-scale HIP. The question of whether to require the HIP pressure vessel to be American Society of Mechanical Engineers (ASME) code stamped, as required by the INEL Architectural Engineering Standard, was discussed. The alternative would be to attempt to get a waiver to the code stamp requirement. The advantage would be that methods of fabricating high pressure vessels not covered by ASME code could be considered. Subsequent discussions with EG\&G Idaho Applied Mechanics personnel indicate that there may be better ways to build a high pressure vessel than the methods covered by the existing ASME code.

The RFP was issued to potential HIP bidders on June 21, and three proposals were received for evaluation. The procurement consists of two parts. The first part is for a conceptual design of a full scale HIP with a 30 -inch diameter by 90 -inch high heating zone. The HIP is to be designed for remote operation, and to prevent contamination of the HIP due to a leaky process canister. The second part of the procurement is for an intermediate scale HIP with a 12 -inch diameter by 30 -inch high heating zone. The 
intermediate scale HIP will be a scaled down version of the full scale conceptual design. The intermediate-scale HIP will be used to test and demonstrate the technology required for remote operation and contamination control. It will also be used to perform a large number of intermediate scale HIP can tests to determine how heat up time and product quality are affected by scale up, and to test formulations prepared using pilot plant grinders, blenders, can filling systems, and other apparatus.

Calcine Immobilization drafted an announcement seeking cooperative help in the development of a canister filling system. A preliminary design of a fluidized bed filling system was completed, and design evaluations have led to the conclusions that the system is better suited for a high throughput process, and that an operational design may already exist in industry. Based on this evaluation, a possible Cooperative Research and Development Agreement (CRADA) has been proposed.

A requisition, cost estimate, and task order for University of Idaho support for Calcine Immobilization process development efforts were prepared. The scope of work for the subcontract will provide expert consultant support in the areas of fluid-bed design and operation. pneumatic transport technologies, and kinetic and thermodynamic modeling.

Dr. Adam Jostsons, Director of the Advanced Materials Program for the Australian Nuclear Service and Technology Organization (ANSTO), visited the ICPP on November 16, 1992. The purpose of Dr. Jostsons visit was to discuss areas of common research and development interest and arrange cooperation plans. Hot isostatic press and uniaxial press technology evaluations, process mechanical systems design and testing, and remote system design and maintenance concepts were discussed as possible areas of cooperation. The meeting was attended by WINCO staff, DOE-ID, and HQ personnel, and resulted in consensus among all parties to pursue an umbrella international agreement.

A preliminary evaluation of Australian-designed HIP canisters was conducted on ICPP glass-ceramic formulations at ANSTO. The canisters were filled, sealed and HIPed in Australia, and returned to the ICPP for evaluation. The HIPed canisters measured 3" diameter $\times 4 "$ tall and were 
estimated to show a $5.15 \%$ increase in performance over ICPP canisters tested to date. Additional work with ANSTO is being pursued.

Summaries of the grinder development work completed in the small-scale Calcine Grinder Setup (CGS) and the design concept for the intermediate-scale grinder were prepared to meet a program milestone. Particle size distribution control and grinding rate information for both a torus jet and fluid-bed mill were presented, and grinder operating parameters, vessel, and instrumentation requirements for the intermediate-scale unit were also discussed. Follow-on testing in the sma11-scale CGS to refine the design concept for the intermediate-scale unit is recommended.

The CGS was modified and operated (three runs completed). The modifications included instrumentation to improve grinding air temperature monitoring and an improved feed pot design to reduce solids holdup. Grinding rates of approximately 120 grams per minute or about $10 \%$ of the anticipated full-scale rate have been demonstrated. Additional runs are planned to improve operations and to further define the design parameters for the intermediate-scale grinding setup.

Semi-continuous calcine grinding tests were initiated on the CGS to evaluate the effect the amount of material in the grinder has on grinding rates. Results of the semi-continuous operation testing indicate that increased material volume in the grinder does not enhance grinding rate for given airflow rates.

Development of a calcine grinding computer model is being performed through a subcontract with the University of Idaho. Fourth order curve fitting techniques are being evaluated to correlate the experimental data. The model will be used to predict the grinding rate of radioactive calcines as a function of particle hardness and size distribution.

Construction and installation of a two-dimensional fluidized bed jet mill was completed for the Calcine Immobilization program. The twodimensional jet mill will be used to determine optimum nozzle configurations, the effects of fluidization on grinding, and the mechanisms of particle 
breakage. A trial run was completed in the jet mill using approximately 15 lbs of +70 mesh calcium carbonate.

Input on the calcine immobilization mixing process and small-scale calcine mixer test vessel design was provided to fulfill a program milestone for a small-scale calcine mixer design by December 31, 1992. The use of a fluid-bed mixer to blend retrieved calcine after the grinding and stabilizing operations is presented, as is the design of the small-scale test mixer vessel. The flow diagram sequence represents a substantial change to the glass-ceramic process concept, and will be fully evaluated before final recommendations are made.

Meetings were held with Analytical Chemistry section personnel to out 7 ine the Calcine Immobilization radioactive and nonradioactive development support requirements. The primary impact on analytical capabilities will be the need for more spectrochemical equipment, manpower and hot cell space. Meetings were also held with WINCO Remote Inspection ersonnel and EG\&G Idaho mechanical engineers to discuss remote HIP process can hendling.

Remote friction weld technology is being evaluated as a method for sealing HIP canisters under vacuum for the glass-ceramic process. The evaluation is being conducted by EG\&G Idaho engineering staff using facilities at the INEL Central Facilities Area model shop. Friction welding is a common manufacturing process for repetitive, assembly line applications.

All testing was completed for Phase I of the inertial welding demonstration for the HIP can closure and a report was received from EG\&G Idaho. The tests defined conditions that resulted in satisfactory welds on the 2-inch test plug. The components/equipment for the inertial welding demonstration program are being dismantled for temporary storage. Further development of the inertial welding process for HIP can closure will be on hold until the final size of the fill opening has been determined.

The Calcine Stabilizer Setup (CSS) was modified to increase throughput capacity and temperature control. A miniature stabilizer was also installed in the CSS walk-in hood to scope requirements for tests to quantify stabilizer operation with radioactive calcines. 
Final SO testing of the CSS was completed and testing with pilot plant calcine was initiated. Initial calcine tests focused on establishing heatup and cooldown times, and heater control and fluidizing air instrument settings. Results from the initial calcine degassing (stabilization) tests in the CSS were received. The results showed that the fluidizing air rate was initially too high and that only bed-size particles greater than $150 \mu \mathrm{ms}$ were denitrated. There was no change in the nitrate composition of the fines $\quad<150$ ums).

A scoping study is in progress to determine important operating parameters in the stabilization (degassing) of a $\mathrm{Zr} / \mathrm{Na}$ calcine in the CSS. Calcines that are not degassed properly will result in a porous waste form with poor leach resistance characteristics. A test was also completed using a $\mathrm{F} 1 / \mathrm{Na}$ type calcine. The $\mathrm{Fl} / \mathrm{Na}$ calcine had significantly faster degassing rates than the $\mathrm{Zr} / \mathrm{Na}$ calcine.

An on-line $\mathrm{NO}_{\mathrm{x}}$ analyzer was received and installed on the CSS. Data from the CSS will be used to develop the reaction kinetic and operating conditions required to stabilize calcine prior to any subsequent high temperature immobilization processing.

Design and fabrication of calcine sampling cans and a carrying basket for obtaining current NWCF campaign bed material were completed, and the canisters were successfully tested for remote handling at TRA. Operations filled each of six canisters with one kilogram of radioactive calcine at the NWCF. This material is being temporarily stored at the NWCF and will be used for advanced waste immobilization development testing.

Calcine Immobilization finalized plans for upgrading the Applied Technology pilot plant Bailey distributive control system for use with the Calcine Immobilization pilot plants. Requisitions for approximately $\$ 93,000$ in necessary components were prepared.

Applied Technology completed enclosed $10 \cdot \mathrm{cm}$ Calciner Pilot Plant Runs SBW4-45b and SBW4-46. These runs tested calciner feed blends of ANN and simulated WM-180 SBW, producing calcine having a sodium plus potassium content of 12 mole\%, and also tested the need for calcium nitrate addition for cold 


\begin{abstract}
ANN/sodium blends. Both runs were terminated voluntarily, but the calcines produced had more agglomerates than normal. Off-gas samples were also collected during these runs to support the NWCF stack off-gas characterization.
\end{abstract}

\title{
Calcine Retrieval
}

A milestone report on retrieval tests on cold ANN/SBW calcine containing 11.5 mole $x$ sodium plus potassium, using caking temperatures of 263 and $310^{\circ} \mathrm{C}$ and a caking pressure of $15.3 \mathrm{psig}$ was issued. This calcine was retrievable after being subjected to $263^{\circ} \mathrm{C}$ but not after being subjected to $310^{\circ} \mathrm{C}$.

Previous tests had shown that this calcine is retrievable at $220^{\circ} \mathrm{C}$, but not at $650^{\circ} \mathrm{C}$. The results will allow the maximum bin set storage temperature to be raised from $220^{\circ} \mathrm{C}$ to $263^{\circ} \mathrm{C}$, and will also increase the allowable calcine heat generation rate for storage of this type of calcine in CSSF Bin Sets 6 and 7.

Insertion of retrieval pipe into storage bins was demonstrated by handling $10^{\prime}$ sections, but a simplification of the method would be desirable. A light-duty structural tube stored as a continuous strip of steel that curls into a tube as it is unreeled appears to have potential for this application. The applicability of this technology to calcine retrieval will be explored by the vendor through rudimentary testing on air in-leakage.

In order to accurately model solids flow in annular bins, a mockup bin analogous to the outer bin of CSSF Bin Set 1 needs to be acquired. Modification of the existing retrieval bin in the Cold Prototype Mockup was investigated. Due to the apparent lack of vessel documentation, fabrication of a new bin appears to be the most attractive option.

Requisitions for a full-scale retrieval mockup testing subcontract and Test Reactor Area (TRA) retrieval pilot plant modification equipment needed to support evaluation of CSSF Bin Set 1 were prepared. This hardware will be used to support development of design parameters for full-scale retrieval and techniques for remote modification of CSSF Bin Set 1 for retrieval access. There is no retrieval access designed into CSSF Bin Set 1 and the structure will require modification. Retrieval techniques were demonstrated for a system approximately $1 / 3$ the scale that is required for CSSF Bin Sets 6 \& 7 . 
A full-scale demonstration is necessary to ensure that unforeseen difficulties do not arise in the radioactive application of these techniques.

Calcine retrieval activities have centered on work to be done to determine conditions within the closed vault of CSSF Bin Set 1 . Concerns about material conditions and seismic standards that the facility was constructed to drive the need to inspect the vault areas. As a result of a meeting held in Apri1, a Value Engineering (VE) session was held to verify the approaches to inspection of CSSF Bin Set 1 . The results showed a need for a staged approach to inspection involving: (1) inspection through existing hatches. (2) traversing the vault air inlet duct with an instrumented remote vehicle, and (3) boring test holes into the concrete at the corners of the bin vault to provide a more direct perspective and to acquire concrete samples.

A computer program was developed to model various retrieval equipment and sequence scenarios methods that would minimize waste form composition and additive variability. Initial work with the program shows that the use of large batch $\left(100-120 \mathrm{~m}^{3}\right)$ size retrieval scenarios appears to favorably reduce the chemical concentration range span of the waste forming compounds.

A report that evaluates various bin set retrieval and transport options was issued, completing a program plan milestone. This report concludes that pneumatic retrieval, followed by dilute-phase pneumatic transport to the treatment facility, are the preferred options for calcine retrieval and transport. If the calcine is to be dissolved prior to final treatment, then an evaluation of the cost of pneumatic transport versus dissolving the calcine at the bin sets and gravity draining the liquid should be completed.

The scope-of-work to perform full height calcine retrieval tests was completed and a requisition for a retrieval mockup (to be assembled off-site by a contractor) is being prepared for bid.

WINCO prepared a one foot diameter, plexiglass annular bin to develop methods of calcine retrieval from annular bins such as the bins in CSSF Bin Set 1, and a run plan for this testing was drafted. A test will be performed in the mockup using air injected tangentially above the solids to cause the solids to drift around the annulus and past a pneumatic vacuum retrieval 
nozzle. If successful, this method of retrieval would significantly reduce the number of penetrations required to retrieve the calcine from CSSF Bin Set 1.

A 1988 seismic evaluation of CSSF Bin Set 1 indicated that release of radioactive material may be possible in the event of a design basis earthquake. However, the report stated that a more rigorous and extensive analysis might show that such a failure is unlikely. As a result of this 1988 evaluation there is a line item project scheduled to begin design of a calcine retrieval system in FY.97. An inspection to determine the condition of the inside of the vault is needed to evaluate the justification for this project. A work order to lift the hatches and inspect calcine storage CSSF Bin Set 1 was submitted and is currently in Engineering. This work will be similar to the vault coring done by West Valley for access to their storage tanks. Engineering drawings of the equipment used at West Valley and reports regarding the integrated remote operation were obtained. These contacts resulted from participation in a technical exchange held at Westinghouse Hanford.

Appropriate remedial action for Bin Set 1 depends on the condition of the vault and bin structure. Specifying the remedial action requires inspection of the vault. A draft Environmental Checklist was begun, with completion pending acquisition of data regarding location of affected Environmentally Controlled Areas.

A formal estimate of \$150K to install an inspection port on CSSF Bin Set 1 was received from Engineering Estimating.

WINCO Projects submitted a scope of work to EG\&G Idaho to request a feasibility study for proposed a project to perform an inspection of CSSF Bin Set 1 . This feasibility study will resolve questions of location, technology and accessibility for deriving the most information from the project with minimum cost. Calcine Retrieval personnel contributed to the content of the scope of work and continue to coordinate the activity. In parallel with the bin inspection project. Calcine Retrieval personnel will be involved in developing the Short Form Data Sheet for the CSSF Bin Set 1 Line Item Project. 


\section{GRAPHITE FUELS DISPOSAL}

\section{Disposal Criteria}

WINCO employees visited and held discussions with ORNL personnel concerning High Temperature Gas-cooled Reactor (HTGR) fuel characteristics and criteria for direct disposal of graphite based fuels. ORNL has considerable information on graphite characteristics, but much less information directly related to direct disposal of FSV spent nuclear fuel. ORNL personnel recommended further contacts with PNL and with HTGR waste disposal personnel in Germany.

Extensive FSV spent fuel fabrication and performance information were obtained from ICPP. Public Services of Colorado (PSC), and EG\&G Idaho sources. A similar effort is in progress for Peach Bottom graphite fuels.

A list of regulatory drivers for disposition of graphite and special fuels was prepared for DOE-ID use in defining funding priorities and manpower levels for the tasks associated with the spent fuels programs. A study on considerations for direct disposal of graphite based Fort St. Vrain and Peach Bottom spent reactor fuels was preformed to gain a current understanding of regulations governing the disposal of spent graphite fuels.

Contacts were made with General Atomics (GA), in San Diego, concerning FSV and Peach Bottom fuel elements. A GA report discussing post irradiation examination of Peach Bottom Core-2 fuel was obtained. This report showed several cracks in the donut-shaped fuel segments, one of which broke in half while being handled by the manipulator. Fuel burnup and nuclide concentration data on computer diskette are being requested from FSV. Efforts to obtain information on HTGR spent fuels continue.

Assembly of data on the graphite fuels for the repository PA was completed. The fuel data included radionuclide inventories, heat generation rates, waste form mass and volumes, and leach rates for three potential waste forms in 24 and 26 inch canisters. 
A model for carbide reaction of open FSV fuel particles with water was completed. The calculations show a combustible gas release rate of about 3 liters per hour for the whole fuel mass with a $10 \%$ water-particle exposure. Data were provided to SNL personnel.

Disposal criteria for graphite based spent reactor fuels were assembled. These criteria satisfy regulatory requirements and the waste acceptance criteria documented for potential geologic repositories.

Criteria for disposal of spent graphite fuel was converted into product specifications. This information will be included in the Preliminary Waste Acceptance Criteria. ${ }^{9}$ document.

A meeting on waste acceptance criteria (WAC) was held to coordinate WAC preparation for HLW, graphite fuel and special fuel. Working together on this will prevent duplication of effort and provide a set of unified criteria.

The Graphite Fuels Document Database was developed and documents were filed. This reference aid is ready for use. A listing of available documents by subject heading was printed and is available for use. One third of the documents received from the New Production Reactor (NPR) document 1ibrary are applicable to the Graphite Program and are being entered into the electronic database.

Review of the Preliminary Waste Acceptance Criteria. ${ }^{5}$ document was completed by DOE and LLNL and the document was issued.

\section{Graphite Block Processing/Disassembly}

Biodegradation of graphite fuels continues to be of some concern for direct disposal. A literature search shows microorganisms have been discovered that metabolize uranium (normally considered lethal to living organisms) in a biochemical reaction involving organic matter (carbon) as food.

Nuclear Fuel Services (NFS), which is just starting to evaluate methods for disassembly of 240 unirradiated FSV fuel assemblies, was contacted for 
future information exchange and the possibility of privatization work.

Information from Great Lakes Carbon (GLC) indicates that the physical properties of H047 are essentially the same as H451 (FSV standard block). Internal review is being made to verify acceptance of H047. GA is sending GLC a letter giving them permission to use detail fabrication prints for fabrication of these test blocks.

A requisition for 40 FSV type fuel blocks was prepared and submitted for procurement. The graphite blocks were to be used for development and testing of methods for disassembly, shredding, burning and processing of the FSV fuel. A significant cost savings will be realized by using a lesser grade graphite that has physical properties very similar to the nuclear grade material. The contract was cancelled due to much lower priority being placed on conditioning of graphite fuels.

A preliminary evaluation of molten salt processing for conditioning of graphite fuels was performed. This method was determined to be feasible for processing graphite fuels, but handling of the off-gas and processing the salt will require additional development work. Problems with molten salt processing of radioactive material are yet to be determined.

\section{Shredding}

Information from equipment suppliers of alternatives for spent fuel size reduction was obtained. These alternatives included electrical discharge, ultrasonic, water jet machining, flame cutting and cryogenic cracking.

Vendors that provide shredding equipment were contacted, and requisitions were submitted for Shred-Pax and Komar to demonstrate their ability to produce $3 / 8$ " sized particles from FSV graphite fuel blocks. These tests successfully evaluated the capability of commercial equipment to size graphite pieces suitable for feed to a proposed graphite burner unit.

Graphite pieces were prepared and shipped to the two shredder equipment vendors for size optimization tests. At Shred-Pax, three blocks were shredded using an AX-200 shredder for initial shredding and an AX-15 for final sizing. 
A uniform 3/8 inch particle size with fines was produced. Pieces greater than 3 inches would not readily feed into the AX-15 and required recycling or extended shredding time. Shredding tests completed at Komar Industries demonstrated the ability to provide graphite block material in a size required for burner testing. A combination of two shredders was used to meet this requirement.

The AX-150 Shred-Pax shredder located at the Process Experimental Pilot Plant (PREPP) facility was identified as possible support equipment for future development work. EG\&G Idaho is currently reviewing options for future use and disposition of this facility.

A letter was issued to the CBD identifying the procurement of graphite blocks for disassembly and process testing.

A criticality study that provides support for conceptual design of graphite fuel separation and conditioning processes was completed.

There are a few commercial, hammermill like units that will reduce the graphite compact matrix and particles to $\sim 200$ mesh simultaneously with the compacts. It may be better to use two pieces of equipment depending on whether the starting material is the compacts or the burned fuel particles. A scope of work was prepared and NFS investigated pulverization of graphite fuel compacts in conjunction. Compacts were crushed and processed through a roll mill with greater than $99 \%$ efficiency in breaking open the silicon carbide shell around the fissile particle.

\section{Drilling}

Faxon Machining Company of Cincinnati performed gun drilling tests in support of mechanical separation of FSV fuel elements. The plexiglass test piece matches very well with existing graphite block sections located at CPP. Small discrepancies noted in fuel channel and cooling hole alignment are apparently due to run-out tolerance when the graphite blocks were machined at GLC. The test piece using aluminum material verified that drilling a oneeighth undersized hole at the theoretical center of the fuel channel on the 
bottom side of the graphite block is a feasible method for accessing all fuel compacts for mechanical separation.

Results of graphite block drilling tests performed at DaCo Machining Company in Salt Lake City indicate that: (1) drill hole breakthrough in graphite blocks can be sensed and will provide a means of control over drilling into the fuel compacts. (2) the wear characteristics of the carbide cutters are much better than originally anticipated and operationa? monitoring should not be a problem, and (3) the proposed dust removal system through the cutter shank is a viable method for this drilling system design.

A preliminary list of drilling and extraction equipment and their specification requirements was received from EG\&G Idaho for review and comment. Resolution of questions will provide information needed for procurement of these items.

The request for bid for procurement of a FSV fuel element separation system was issued, bids were evaluated, and the purchase contract awarded. The system will consist of a drilling station, fuel eject station, pneumatic ram and system controller.

The Level I schedule milestone for procurement of the graphite separation station by September 30, 1993 was met. To complete this milestone a design for the block/rod separation prototype was completed and purchase orders placed. The separation equipment will be delivered, set up and tested by the end of FY-94.

\section{Laser Cutting}

An existing TRA laser cutting tool was modified, and initial tests on graphite cutting were performed. Although the graphite cutting was accomplished, the limited-capacity laser also limited the depth of the graphite cut.

Graphite fuel block samples were prepared at TRA and shipped to Lumonics, Inc., which performed laser cutting tests with a more powerful unit at their facility in Maryland. 
Laser cutting tests performed at the Lumonics facility indicates that their state-of-the-art yttrium aluminum garnet (YAG) laser system is insufficient to provide access cuts into the graphite fuel channels. Apparently the high heat capacity of the graphite material makes it incompatible with laser cutting in the thicknesses required (i.e., the $1 / 4$ to $1 / 2$ inch range).

\section{Burning}

A requisition for consultant support for graphite burning was prepared, and bids were requested. A purchase requisition was also prepared for procurement of shaft furnace construction and testing services.

Five proposals for obtaining a consultant for preparing a report on existing graphite fuel burning and off-gas handling technology were received and evaluated. The contract was awarded to Ron Drake.

The Scope of Work for the shaft furnace contract for burning whole and crushed fuel elements was sent out for departmental review and the comments from the review were incorporated.

An interactive review meeting for the scope of work for development and construction of an experimental shaft furnace for burning graphite was held and all comments were incorporated. A final draft of the scope of work was provided to procurement.

One bid was received on the request for proposals for the shaft furnace. The bid was approximately ten times the budgeted amount for the shaft furnace.

A brainstorming session was held with interested shaft furnace vendors to determine the descoping that could be done to minimize the cost of the furnace. The session was a success, as a number of descoping suggestions were made by the vendors and accepted by the WINCO representatives.

The scope of work for the shaft furnace was modified to make the contract a service contract. Initial work on the shaft furnace was planned to be a proof of concept by an outside vendor. Information from the service 
contract was to be utilized for design of an on-site furnace, if the concept was proven feasible.

Bids were received and evaluated for shaft burning of whole graphite blocks. The contract was not awarded due to new DOE-ID direction for the entire spent nuclear fuel program.

A draft copy of the Criticality Safety Evaluation (CSE) for a graphite burner was obtained. The CSE was reviewed.

Calculations were performed to determine the carbon-14 content of the FSV and Peach Bottom fuels. The information on carbon-14 will be used to define: (1) the removal process for carbon-14 in the burner off-gas, and (2) the degree of carbon-14 removal required for burning graphite fuels.

Contacts were made with Environmental Permitting to obtain assistance in determining the amount of carbon-14 that can be released to the atmosphere during burning of irradiated graphite fuels. The initial response from Environmental Permitting was encouraging, as much of the carbon-14 can be released up the stack.

A university research project for BYU Chemical Engineering students to develop and demonstrate technology to remove semi-volatile fission products from burner off-gas was approved. Contacts at BYU were made to confirm interest and to request a cost estimate of the work. A contract was placed to have BYU students spend much of FY-94 developing and testing equipment for off-gas fission product removal.

Work continues on off-gas flowsheets for burning of graphite fuels. A generic flowsheet was prepared and the options selected. The scheme for offgas treatment relies on multiple treatments to remove the contaminant species in the order of their concentration: (1) gross particulates by using 5 micron sintered metal filters; (2) finer particulates from cooled gas by using 0.5 micron sintered metal filters (condensing semi-volatiles); (3) soluble volatile species, aerosols, and most of the remaining particulates by using a subcooled packed bed "wet" scrubber; and (4) contaminants exiting from the 
scrubber. such as aerosols of contaminated scrubbing liquid and most of the remaining particulate and volatile species, by using a packed bed.

Work on assembling information on the locations of equipment needed to fabricate a subcooled scrubber system for off-gas treatment during burning of graphite fuels was initiated. The cooling unit will have to be procured since many of the existing coolers will not easily operate at the required $-40^{\circ} \mathrm{C}$.

\section{Characterization/Examination}

Spent fuel examination reports on both FSV and Peach Bottom spent graphite fuels were reviewed. It was noted that a GA Peach Bottom inspection report showed that some fuel donuts had cracked during the 700-day irradiation period. It was also determined that the GA hot cell facility near San Diego. California would not be available for further spent fuel examination activities.

Two personnel visited PNL for detailed discussions of their experience in fuel inspection of spent Light Water Reactor (LWR) fuels. A tour was provided of numerous hot cells that are used for post irradiation examination (PIE). These cells are fully capable at this time. A determination was made that considerable potential exists at PNL for assistance in PIE of spent graphite fuels and for assembling data required for repository waste form approval .

Two personnel from PNL visited WINCO and presented a requested proposal for preparing a detailed spent graphite fuel inspection plan. The draft inspection plan was completed five months after funding was received at PNL. A revised scope-of-work was prepared, along with a Requisition for Services. Included in the revision are specific parallel activities that PNL will pursue to prepare their facilities for fuel inspection activities.

A requisition for services was approved for PNL to prepare a detail plan for characterization of spent graphite fuels. Other efforts have started on several issues of characterization, including acquisition of data, shipping requirements, and the definition of quality assurance procedures. 
The contract with PNL was modified at no cost to include seven more milestones as deliverables and to clarify that WINCO will do waste form development and PNL will do waste form performance evaluation. Current issues with the contract include WINCO Quality Assurance requirements, identification and acquisition of literature and documentation concerning fuels and sample sources, sample acquisition, preparation, and shipment to PNL.

PNL began work on the PIE plan development for graphite fuels. Initial work concentrated on administrative tasks for project start-up, detailed manpower requirements planning, assembling a project team, and addressing the internal safety and criticality review requirements associated with a new project.

A purchase requisition for 30 blocks of unirradiated FSV fuel was completed and sent to procurement. The unirradiated material will be utilized for analytical method development for PIE, process development work, and final system operability testing before processing spent graphite fuel. A contract for purchase of the 30 blocks was placed and later cancelled due to uncertainty of acceptance of the materia! by the State of Idaho.

Bids for simulated graphite fuel element blocks and fuel rods were received and evaluation is in process.

An evaluation of hot cell facilities available at the INEL for PIE of graphite fuels favors the ANL-West hot cells. Initial contacts were made at ANL-West to determine the available analytical capabilities and to begin defining scheduling of the hot cells for planned PIE.

Initial preparation of the Environmental Assessment required for performing the PIE of graphite fuels has begun. Negotiations are in progress with ANL-West to determine if a portion of the PIE will be performed there.

Work by EG\&G Idaho is continuing on evaluating options for handling and sectioning FSV fuel for PIE. A draft report summarizing the options and requirements is being developed. 
The Delayed Neutron Interrogator utilized during Campaigns 41 and 42 in the FDP cell is being considered for reuse during characterization of INEL spent fuels. Current discussions have been on the feasibility of keeping the current system intact and modifications to upgrade the system. 


\section{Fuel Characterization/Database}

Special fuels data were assembled in support of the repository PA. The fuel was divided into groups with similar characteristics, and these characteristics were evaluated and summarized on data sheets. The three base waste forms being evaluated are: (1) the fuel is placed in a canister and the canister void space is filled with a nonradioactive glass, (2) the fuel is placed in a canister and the canister void space is filled with a glass-ceramic made from calcine, and (3) the fuel is placed in a canister and the canister void space is filled with borosilicate glass made from calcine. The above information was included in an appendix to a report issued by SNL.

Information from the fuel database was used to obtain fuel characteristics that SNL used for the repository PA. The fuel data were placed in one of two groups (high uranium enriched or low uranium enriched), which were used to estimate total fission products, actinides, and heat generation. The information was summed and averaged to provide values for the average canister and the expected range. Gas generation data and hazardous material content information were also reported.

The available fuel characterization data on fuels stored in CPP.651 and the Unirradiated Fuel Storage Facility were entered into the WINCO fuel database. An in-depth characterization of the Systems for Nuclear Auxiliary Power (SNAP) fuels at the ICPP was conducted as part of an evaluation of the storage condition of the fuel.

A11 the foreign fuel stored at the ICPP was characterized. The fuel database was modified to include a history section for each of the fuels. A summer student was hired to work on: (1) other fuel database enhancements, (2) a QA plan, and (3) further data gathering and entry.

Preliminary information about the spent nuclear fuel stored at rest Area North (TAN), TRA, and Power Burst Facility (PBF) was received from EG\&G Idaho. The data was validated and entered into the WINCO spent fuel database. The 
fuel characterization report on fuel stored at the INEL by EG\&G Idaho was prepared and issued, completing a program milestone.

The Spent Nuclear Fuels characterization status report with provisional characterization criteria was issued, completing a program milestone. This report summarizes the characterization work that has been completed and the present status of the work. It also contains provisional criteria for fuel characterization.

The fuels database was demonstrated to WINCO, EG\&G Idaho and DOE-ID personnel. The demonstration showed the versatility of the database and the information that can be obtained from it. Several suggestions were received on how the database could be upgraded to provide more helpful user data. These will be incorporated in the database.

Information from the database and characterization reports was used to prepare a briefing for the DNFSB on fuels stored at the ICPP.

A proposal for establishment of a national spent fuel database was prepared and submitted to DOE-ID. The proposal was based on extension of the existing database developed by WINCO for fuels stored at the INEL. The responsibility for National Database lead went to EG\&G Idaho with WINCO in a supporting role.

A presentation on the national spent fuel database was made to the DOE Waste Form Barrier/Canister Team.

A Quality Plan for the fuel database was prepared and issued for review. Review comments are being incorporated and the quality program added to the database.

The fuel database user manual was rewritten to include added updates. An option to the database was added to include individual fuel histories.

The information about the spent nuclear fuel (SNF) in storage at the ICPP currently in the database is being validated against original documents. 
Several discrepancies were noted in the information supplied by EG\&G Idaho. These were resolved and more information added.

A programming bug in dBase IV version 1.5 was discovered that affected the notes section of the spent nuclear fuels database. The version was updated to 2.0. which is supposed to fix the problem, and the notes section was appropriately modified. The data in the confidential and unclassified parts of the database were updated to reflect current fuel receipts.

\section{Euel Dispositioning}

Meetings were held to identify and evaluate several candidate technologies for possible use in dispositioning spent fuel for repository storage. The pros and cons of approximately nine different technologies were discussed.

A tour of the EG\&G Idaho vitrification laboratory facilities was made to assist in evaluating use of vitrification as a technology for final conditioning of spent nuclear fuel. Talks were held with people doing vitrification work and how it can apply to special fuels. Four scientists from ANL-East spent two days presenting their integral fast reactor (IFR) technology. Discussions of application to our problems were very beneficial. Neither vitrification nor IFR technology will apply to all of the special fuels. It appears that the major technology selected will require additional steps or additives and possible waste options to meet all criteria.

DOE-ID was requested to retain some unirradiated fluorinel scrap material for process development.

A study was conducted to determine the spent fuel needs for both a spent fuel canning facility and a multi-function pilot plant facility. The study is to determine if both facilities are needed or if one could be used.

A VE session was attended for the Fuel Canning Facility. The preferred solution is to convert the FDP cell to a dry canning and fuel characterization facility. The alternative solution consists of converting the IFSF handling 
cell to a dry canning facility, with an alternative location for a characterization facility.

A presentation was prepared for the Office of Nuclear Safety on fuel in storage at ICPP. The information was obtained from the WINCO spent fuel database.

DOE-HQ is considering classifying all spent fuel as waste. Appropriate issues in responding to this classification were identified, hazardous constituents contained in spent fuels were evaluated, and an inventory of potentially hazardous fuels was prepared. Several fuels were identified that might fall under RCRA requirements if spent fuel is classified as a waste. The information was given to WINCO Environmental Compliance for communication to DOE.

A detailed evaluation of the SNAP and Atomics International fuels stored in the CPP.603 basins was completed. This evaluation included: (1) history of the fuel. (2) contents of each of the storage cans, and (3) present condition of the storage cans. Video tape was reviewed to confirm the suspected condition of the fuels, and the necessity of recanning or other dispositioning activities as soon as possible.

The fuel dispositioning criteria development plan was completed on schedule, satisfying a WINCO program milestone.

Participated in the PWAC to develop criteria for various waste forms including HLW. The team effort will el iminate redundancy in the waste criteria program.

Preliminary planning is being done on a possible dry fuel storage test to be performed at the ICPP using irradiated aluminum fuel.

The Special Fuels organization made a proposal for dry canning of CPP. 603 fuel underwater to the fuel canning task team. The proposal includes a design for canning that would keep the canister from coming in contact with the water. This would keep the outside of the canister from becoming contaminated. 


\section{National Spent Fuel Program}

The Spent Fuel group actively participated in the National Spent Fuel Program and attended Technology and Database Technical Working Group (TWG) meetings.

WINCO supported the Spent Nuclear Fuel Database TWG in the design of the database and the preparation and review of design documents. A national meeting was attended and a presentation was given on the proposed data fields. Preliminary data fields were established and the first call for data to be included in an updated SNF background report was issued.

At the request of the database TWG. WINCO put together a small group of categories of SNF to be used in evaluating existing storage facilities for storage of additional SNF. Eight groupings were developed based on enrichment, size, quantity, and susceptibility to corrosion.

A draft technology integration plan for the DOE NSNF TWG was prepared. comments were incorporated, and discussions were held. This plan includes work that must be completed to direct SNF technology integration and development. The plan is being reviewed and will be presented to the NSNF TWG at the next meeting. The plan is designed to utilize the expertise at each of the DOE facilities and to address the integration of technologies to solve the DOE SNF problems, both short and long term.

Input was provided for the appendix to the national plan on WINCO site specific activities.

WINCO completed a draft of an Environmental Assessment (EA) for the treatment for disposal of foreign fuels at the ICPP. This EA will be incorporated into an overall EA for the receipt and processing for disposal of foreign fuels in the United States. The draft EA includes a description of the facilities available at the ICPP for processing foreign fuels, and the risks associated with operation of these facilities. 

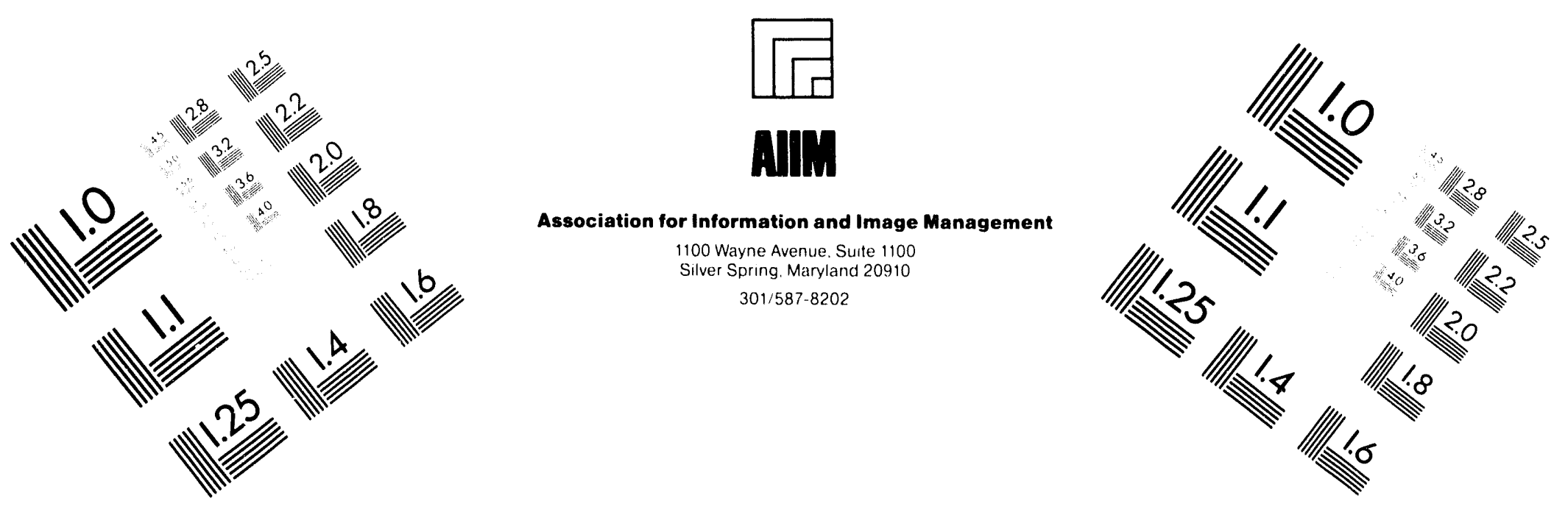

\section{Centimeter}

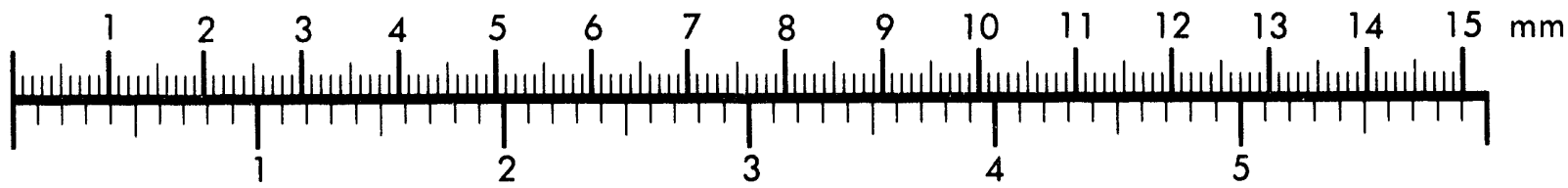
Inches
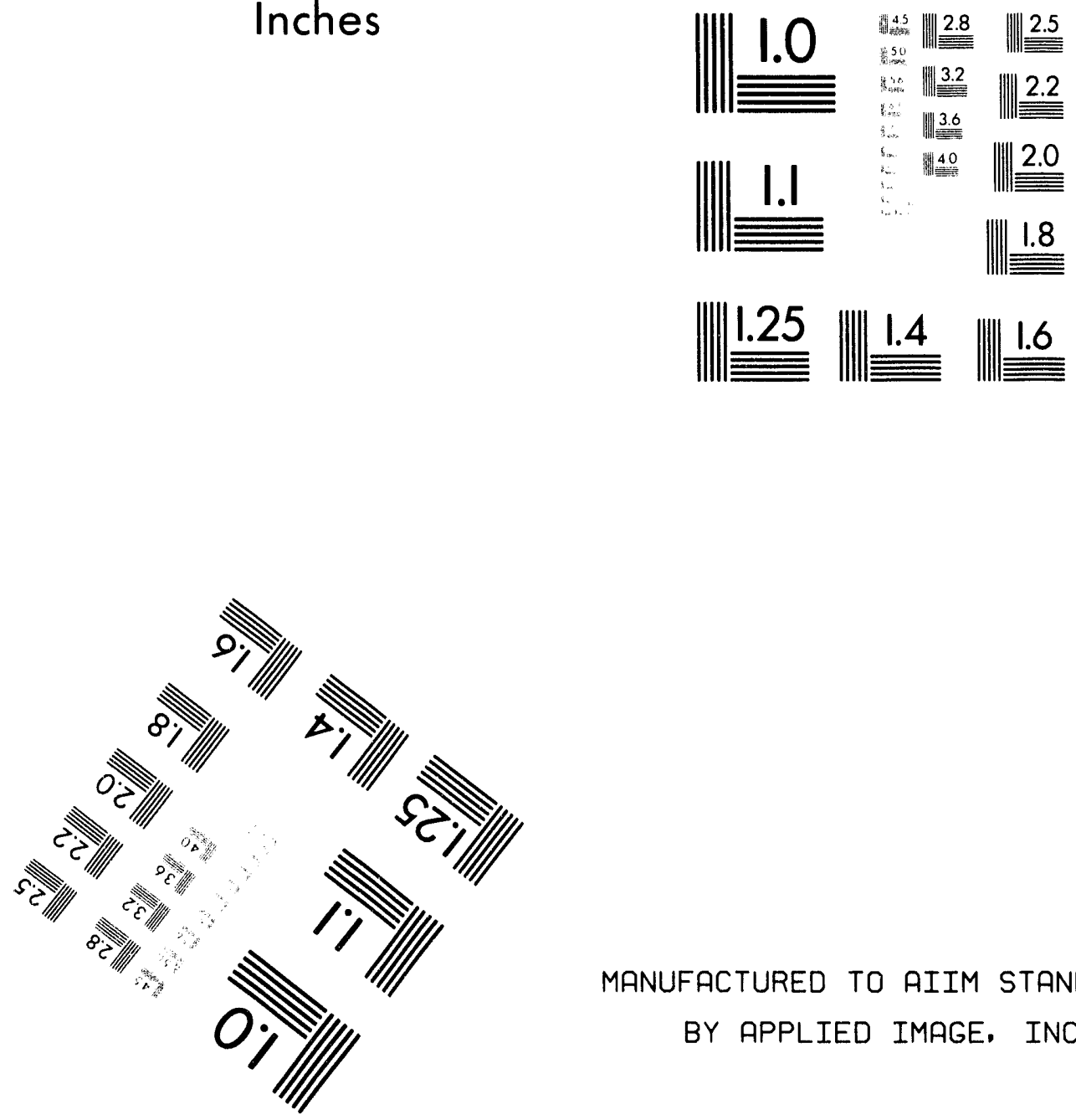

MANUFACTURED TO AIIM STANDARDS

BY APPLIED IMAGE. INC.

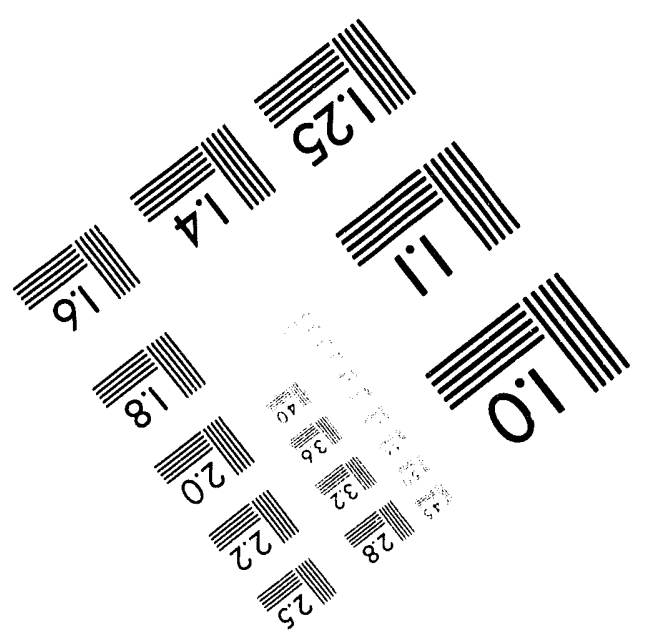



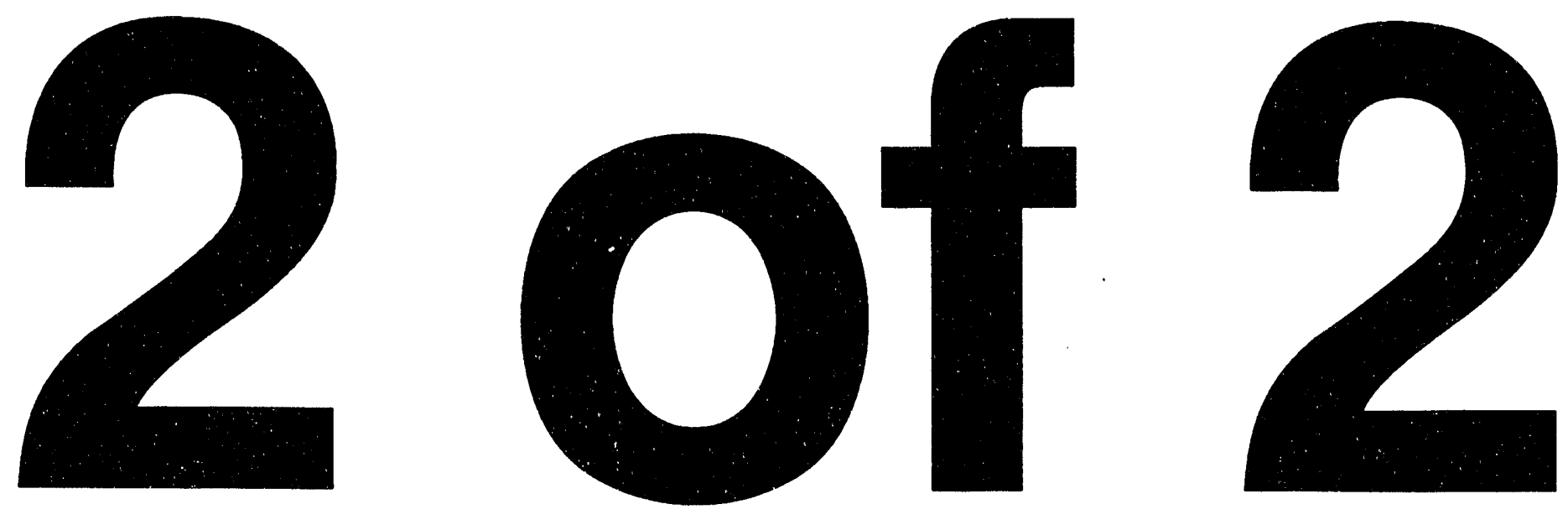


\section{RADIOACTIVE SCRAP METAL RECYCLE}

\section{Metal Recycle Program Plan}

Following discussions with the EM-30 program manager at DOE-HQ, the Metal Recycle Program Plan was revised to reflect the agreed-upon scope. WINCO wi11 support EM-30 in developing and implementing strategies for management and disposition of RSM in the DOE complex, with emphasis on recycling to minimize disposed radioactive wastes. WINCO will also assist in coordinating DOE activities in developing and demonstrating metal recycle technologies and criteria.

Meetings were held with other GOCOs to present WINCO's program on RSM, to determine resources required to characterize RSM at each site, and to understand the storage areas of existing RSM.

A decision tree was developed to guide the process of recycling RSM. Among the important decision points in the tree are: (1) the availability of technology, (2) level of radioactive contamination. (3) beneficial reuse of materials, and (4) cost/benefit analyses.

The metal recycle program was presented to EM-37 in support of DOE's spent fuel program. Spent fuel could eventually be stored in containers fabricated from recycled RSM. The lletal Recycle program was also presented to DOE-RW in support of the universal container program. Universal containers for commercial spent fuel storage could also be fabricated from RSM.

Metal Recycle program objectives are to: (1) provide lead support to EM30, (2) assess SS melting technologies, and (3) recycle ICPP contaminated stainless steel (SS). Specific activities developed for each program objective include the following: (1) melting and decontamination of radioactive SS; (2) investigating the recycling of radioactive carbon and stainless steels, lead, and copper; (3) investigating the fabrication of DOE spent fuel canisters from recycled RSM; (4) exploring bar coding as an inventory tool in characterization of RSM; (5) examining size reduction techniques; and (6) performing life cycle cost using an existing facility, a central facility, or regional facilities. 
An overview of the WINCO national Metal Recycle program, and its relationship to other DOE programs, was presented in Washington, D.C. to DOE representatives from EM-30, EM-40, and EM-50. This demonstration, which was planned out by representatives from WINCO, SRS, and ORNL, is scheduled to be funded beginning in FY-94. Metal feedstocks for the demonstration will come from the SRS and the ICPP.

\section{Scrap Metal Characterization}

Personnel who will support inventory and characterization efforts for RSM were contacted at SRS, Nevada Test Site (NTS), Rocky Flats, LANL, SNL, and Hanford. RSM storage areas were visited at each of these sites to initiate these efforts, and the WINCO Metal Recycle program was presented. Initial requests were made to determine the level of funding and resources required to characterize metals at each site. Sub-contracts were prepared for participation of each site in the Integrated Data Base data collection, and a scope of work was developed for inclusion in the sub-contracts.

DOE EM-40 signed an Interagency Agreement with the EPA Office of Radiation Programs to fund an EPA survey on the status of metal recycle, including RSM inventories, recycle technologies, regulations and criteria, etc. The EPA subsequently contracted Sandy Cohen Associates, Washington, D.C., to perform the study. The scope and funding level are such that the study will be necessarily limited and consist primarily of literature surveys. Since many of these activities are similar to some of WINCO's tasks supporting EM-30, discussions with EPA personnel were held to coordinate WINCO efforts with EPA activities.

A meeting was conducted the week of February 22, 1993, to finalize contractual arrangements and to discuss various aspect of the RSM survey form and data collection. Representatives from EM-30, EM-40, EM-20, NRC, and six DOE sites (INEL, LANL, Hanford, NTS, Rocky Flats, and SRS) were in attendance.

The Metal Recycle Subsection held a follow-up meeting in Salt Lake City on April 20-21, 1993, to discuss: (1) radiation survey methods and criteria used for release of scrap metal to the public sector; (2) RCRA regulations on hazardous waste (40CFR Parts $260-270$ ) that may require characterization of 
their hazardous content; (3) the proposed survey form format: and (4) methodologies for surveying types and amounts of metal and radioactivity in scrap metal.

The group was not able to reach a consensus on the applicability of RCRA regulations to scrap metal but Mike Gibl in from EM-321 indicated he would form a team from representatives of EM-30, EM-40, EM-50 and the DOE Office of Environment, Safety and Health (DOE-EH) EH-20 to provide a draft guidance letter on this issue for a subsequent meeting of the group during June 1993.

Numerous comments were received by the group on the proposed format of the scrap metal survey form, and comments were incorporated. Negotiations were initiated with the NTS to use one of their scrap metal yards for a prototype field survey in the second half of FY-94. The field survey will serve to determine the practicality of the survey form and survey methodologies for potential application throughout the DOE complex.

The Metal Recycle Subsection held a third and final meeting with site subcontractors and DOE representatives in Salt Lake City on June 22-24, 1993.

An electronic library for filing and retrieving reports gathered by the Metal Recycle subsection was implemented. The files are stored in dBase IV; a menu-driven Clipper-language code was developed for editing, viewing, and searching the data base. The library and Clipper code can be loaded on any computer with DOS system 3.0 or later version.

The Pittsburgh Conference was attended the week of March 8, 1993 for identifying analytical instruments that Metal Recycle will use to characterize RSM. Vendors were contacted to obtain information about portable instruments that will identify metal components and contaminants on the metal.

Two instruments that will be used to identify metal components and contaminants on the metal were demonstrated. The first instrument was a Nomad gamma spectrometer manufactured by EG\&G Ortec. The instrument did not perform within the required specifications and will not be considered further. The second instrument was an X-met $880 \mathrm{X}$-ray fluorescence manufactured by Outokumpu. The instrument performed well and will be considered for purchase. 
The $x$-ray fluorescence-instrument was put out for bid, and two companies (TN Technologies and Outokumpu) expressed interest in providing the instrument.

Metal Recycle personnel completed a study entitled, Decontamination of FAST (CPP -666) Fuel Storage Area Stainless Steel Fuel Storage Racks ${ }^{10}$, in fulfillment of the Metal Recycle program milestone, "Survey Surface Decontamination (Decon) Methods and Choose Method for Use on FSA Stainless Stee1." A report entitled, Evaluation of the Electrorefining Technique for the Processing of Radioactive Scrap Metals ${ }^{11}$, was issued to satisfy another milestone.

\section{Scrap Metal Melting}

Site visits were made to Mountain States Energy (MSE) and Montana Tech. At MSE the centrifugal plasma furnace facility was toured. Discussions were held with the staff to determine the potential applicability of the technology to processing RSM for recycling.

Montana Tech has experimental facilities and staff especially suited for evaluating plasma melting of metals, and for developing slagging technologies for purifying melted scrap metals of radionuclide contaminants. A small "button" furnace is available for performing experiments to characterize the process and to produce processed metal for metallurgical evaluations. A twoyear contract was awarded for funding two masters degree graduate students to develop slag chemistry, evaluate metallurgical and phase characteristics of product, and perform pilot melting tests at the Retech facility in Ukiah, California by cold hearth plasma melting and induction melting.

Experimental decontamination methods under investigation for ICPP contaminated SS include laser ablation decontamination and high temperature processing techniques. A contractual agreement with Ames Laboratory for laser ablation was established in conjunction with the Decontamination Development program. A contract for melt and decontamination studies at Montana Tech was finalized and experimental work has started. 
ESCO Corporation of Portland, Oregon, and the Oregon Graduate Institute of Science and Technology (OGI) of Beaverton, Oregon, were visited to assess their capability to provide technical assistance to the Metal Recycle program. The spiral welding techniques used by ESCO may be applicable to canister fabrication from RSM.

A requisition to place a contract with the OGI is presently at EG\&G Idaho procurement.

Discussions were held with Portland General Electric (PGE), the operator of the soon-to-be D\&Ded Trojan Power Plant, with regard to the possibility of a cooperative activity invclving the D\&D project and the associated contaminated scrap metal. PGE expressed interest in recycling the primary cooling system into DOE Universal Containers for storage and disposal of spent fuels, and contributing to a cooperative project a large fraction of the projected cost of shipment and burial of the LLW metal (on the order of $\$ 25$ million). A written summary of WINCO'S meeting with PGE was provided to DOEID. This information was forwarded to DOE-HQ.

Northwest Pipe and Casing was visited to inspect their facility for spiral welding of large diameter pipe from narrow rolled-steel sheet. Application of this technology to the production of HLW cans from contaminated scrap metal could lead to large cost savings for rolling mill equipment.

The U. S. Bureau of Mines Research Center, Albany, OR, was visited to inspect their research facilities for possible support of Metal Recycle experimental activities.

Discussions were held with personnel from SRS on melting the SRS's tritium-contaminated SS to examine the melt composition.

The David J. Joseph Company, a scrap metal shredder operator, was visited on February 19, 1993 with the objective of seeing how a metal size reduction facility operates in an industrial setting.

A meeting was held at the Special Manufacturing Capabilities (SMC) Project with representatives of Babcock and Wilcox Idaho (B\&W). The purpose 
of the meeting was to review SMC metal working capabilities and to determine if they can be used to recycle RSM. SMC has equipment that is used to form depleted uranium shapes. The equipment that Metal Recycle believes might be used to recycle RSM include: (1) a 4-high rolling mill, (2) a roller leveler, (3) a metals shear, and (4) heat treating furnaces. A joint development program for the rolling of recycled RSM SS was also discussed.

A technical interchange meeting was held in Idaho Falls with representatives from WINCO, Montana College of Mineral Science and Technology, OGI, Savannah River Technology Center, and DOE-ID. The meeting discussed SS melting technology, slag/metal interactions, literature surveys, and melting of tritium contaminated SS.

A meeting with ANL-East personnel was held to apprise Metal Recycle of IFR activities related to fuel processing and materials research. In particular. ANL-East's experimental activities dealing with electro-refining and SS processing were of interest.

A survey to identify cold SS scrap located at ICPP was undertaken and over 10,000 pounds were located. Montana College of Mineral Science and Technology was sent 4,450 pounds of this steel to conduct melting tests. An additional 4,200 pounds of this material were sent later in the year, for a total of 8,650 pounds.

A preliminary cost estimate was performed on fabricating a HLW dry storage canister using RSM SS instead of clean SS. An estimated $\$ 320,000,000$ over 20 years is saved when RSM SS is used.

Manufacturing Science Corporation (MSC) and Scientific Ecology Group (SEG), metal melting and fabricating companies located at Oak Ridge, TN, were visited on March 15-16, 1993 to assess their recycling and fabrication technologies.

Visits were made to SNL, LANL, and WIPP to discuss issues relating to the recycle of RSM. The Liquid Metal Processing Facility at SNL is a world leader in research, development, and application of casting technology. They have assembled the Specialty Metals Processing Consortium, which consists of 
11 companies that produce or use specialty metals. WINCO will explore the possibility of using SNL as a technical consultant to our program with a special emphasis on melting tritium contaminated SS. The Process Engineering Group of LANL has a contract with the OTD for the treatment of mixed waste with an emphasis on contaminated metal. They have a contract with the Center for Iron and Steel Research at Carnegie/Mellon University for a literature search and melting program. WINCO and LANL will share the results of their respective programs. WIPP was visited as a prospective customer for recycled metal.

A Saving Through Sharing initiative is being developed between WINCO and Savannah River Technical Center (SRTC) on the recycle of radioactive contaminated SS. WINCO will develop the general technology of SS melting/refining and SRTC will focus on melting tritium contaminated SS.

On May 13, 1993, Metal Recycle group members visited Geneva Steel, a steel making facility, to inform Geneva of the Metal Recycle program plan and to assess their interest in participating in the program. The group also went on a tour of Geneva's Q-BOP furnaces, blast furnaces, and fabrication facility.

PGE, OGI, Teledyne Wah Chang, and Pacific Nuclear met with Jeff Williams of DOE-RW to discuss a proposal to fabricate a Nutech Horizontal Modular Storage System (NUHOMS) canister from radioactive recycle metal. The discussion was favorably received, and Mr. Williams will contact EM-30 and DOE-ID to develop guidelines for cooperative agreements. A letter of intent to submit an unsolicited proposal was submitted by OGI to DOE Headquarters.

The Conference/Workshop on the Recycle of Radioactively Contaminated Metals and Alloys, May 19-21, 1993, at Augusta, GA, was attended to become more completely informed of the metal recycle activities at other DOE facilities and in the private sector. Contacts were made with SRS, Hanford, LANL, SNL and ANL personnel participating in metal recycle activities at those facilities. Discussions included personnel from the private sector representing Battelle (Columbus): Quadrex, Newport News, and B\&W. Personne1 from EPA and DOE-HQ were also present. 
A report on decontamination of metals by melt refining/slagging was issued by Montana College of Mineral Science and Technology on June 25, 1993. This report was transmitted to DOE-ID to meet the Metal Recycle Sub-Section program milestone. "Conduct a Literature and Vendor Survey which Identify al1 Melting Technologies for RSM." which was scheduled for completion on June 30 . 1993. The report focuses on decontamination of RSM by melting, and removal of radioactive contaminants by reaction with appropriate metallurgical slags and volatilization. A number of slags were identified as being effective, but an optimum slag could not be specified based on the literature. The information in this report is being used to formuiate a laboratory melting/slagging program.

Personnel attended the final EM-50 D\&D Integrated Demonstration workshop, and a draft plan for a demonstration of RSM recycle was completed. The demonstration will utilize SS feedstocks from the INEL and SRS for fabrication of LLW containers. The containers will be used across the DOE complex.

An assessment is being performed on recycling radioactively contaminated lead. DOE owns 8.6 million pounds of contaminated lead, of which the INEL has 2 million pounds. The INEL currently plans to decontaminate their contaminated lead at CPP.659 decontamination facility. Since the U.S. consumes millions of pounds of lead each year, the recycle of contaminated lead could be a vital part of WINCO metal recycle program.

OGI was sent 10,400 pounds of scrap 304L SS for melt research. Metal Recycle personnel have identified over 500,000 pounds of $304 \mathrm{~L}$ that can be used for dry canister storage of CPP.603 spent fuel assemblies.

On August 23, 1993. Metal Recycle took ownership of all of the remaining FPR 304L SS. By doing this, Metal Recycle received over 200,000 pounds of 304L SS to be used in melt research and fabrication.

A contract was awarded to Alpha Engineering to perform a conceptual design and cost estimate for an off-site melting/fabricating facility. Included in the design will be process flow charts, plant plan drawings, and a major equipment list. 
A technical review of the proposed "Master Alloy" melting activities at OGI and Montana College of Mineral Science and Technology in which alternative experimental schemes were evaluated was completed.

Metal Recycle submitted a proposal to use University Exploratory R\&D Proposals funds to study electrochemical refining techniques for radioactive SS scrap metals at the Colorado School of Mines.

\section{Cost Reduction Efforts}

Contacts were established with public utilities concerning metal recycle, as requested by DOE-ID. The possibility of privatization and costsharing appears very promising.

Evaluation was initiated to investigate the cost savings of privatizing the recycling activities. Preliminary results indicate that private recycling of contaminated steel into universal containers that would be needed by utilities over the next 20 years could save some $\$ 300$ million (12 percent) over burying the LLW metal and purchasing cold canisters.

Efforts are in progress to identify and contact additional utilities that might be interested in participating in metal recycle technology exchanges. The Colorado Center for Environmental Management, which has excellent industry connections, was contacted to review their interest in Metal Recycle activities.

Contacts were made with Electric Power Research Institute and Yankee Rowe in order to better gauge interest in recycling and the supply potential of RSM from commercial utility sector. The metal recycle effort is dependent upon supply of available feedstock and demand for recycled products; because of this, commercial utilities may be a significant player. The response from these inquiries was that there is an interest in on-site dry storage canisters as a practical reality, as well as a strong financial interest in being able to eliminate the liability of burial costs. Yankee Rowe's needs are being deferred until the year 2000, and when the burial site at Barnwell closes mid 1994, they will have no other disposal options. 
Dr's. N. Iyer and M. Louthan of SRTC were visited to discuss a cooperative metal recycle effort with them, to tour their facilities, and to address various aspects of SS metal recycle.

An advertisement was prepared for placement in the CBD seeking private companies with decontamination, melting, and fabrication capabilities to participate in a cost sharing/technology management agreement. A second advertisement was placed in the CBD. May 5, 1993 seeking an expression of interest from private utilities and other private companies that have a need for RSM disposition. Twenty six private companies responded to the first CBD advertisement, published April 14, 1993.

An information packet was prepared and sent to the thirty three private companies that responded to the two advertisements published in the CBD. Each company was invited to attend a strategic meeting on August 2, 1993, to discuss forming a cooperative agreement to recycle radioactive SS.

Metal Recycle held a privatization meeting August 2, 1993. In attendance were WINCO personnel and representatives of 15 companies. At the meeting, the group discussed forming a cooperative agreement to recycle radioactive SS and developing the SS melting workscope.

\section{Scrap Metal Regulations}

A meeting was held with personnel from EH-20 to determine status and plans regarding criteria for recycle of RSM. DOE-EH must give approval for unrestricted use (URU) of RSM. Current1y. DOE Order 5400.5, which is patterned after NRC Regulation Guide 1.86, governs release for URU. It contains de minimis levels for surface contamination activity, but not for volumetric contamination. DOE is considering adopting an interim standard in place of the Reg. Guide 1.86 basis while waiting for EPA to establish standards. In addition, DOE will propose 10 CFR 834, Radiation Protection for Public and Environment, that will emphasize as low as reasonably achievable (ALARA) analyses in terms of doses. WINCO will continue interfacing with EH20 to remain abreast of developing criteria for URU of RSM, ensure that the integrated data base development for the Metal Recycle program will provide 
information needed by EH-20, and provide other input to the criteria/regulatory process as necessary.

The milestone to complete a review of all regulations associated with the unrestricted release of radioactive materials was completed on schedule. Several initiatives were attempted by the NRC and DOE in the past to legislate "below regulatory concern" levels of radioactivity. These efforts were halted due to negative public response. 


\section{Evaluation of Potential Uses of FDP and FPR}

A VE study that incorporated a Kepner-Tregoe decision analysis was performed for FDP and FPR usage. Evaluations were performed based on the preliminary study by Facility Support on the use of the FPR and FDP facilities

- for hot and cold pilot plant development work, and the VE study that identified FDP as a candidate for the fuel canning. The latest VE study evaluated all potential uses for FPR and FDP (i.e., fuel canning, filter dissolution, etc.). The study found that the two existing structures are compatible with the requirements for development facilities.

A task assignment was made to investigate the storage of hot filters in FDP and the permitting requirements to do so. This assignment was compared with the alternatives identified in the VE study of FPR and FDP. Two VE studies of FDP for uses other than for hot filter storage have now been completed. The Facility Support Section's VE study identified Fuel Canning as one of the best uses for FDP.

The evaluation of the potential uses of FDP and FPR was completed on March 31, 1993 to complete a DOE HQ milestone.

\section{Space Requirement Study/Facility Requirements Evaluation}

Studies of the cold and hot pilot plant space requirements were completed, and CPP-637 utilization, as well as the need for new development facilities was determined. Meetings with all of the Applied Technology sections identified the number, size, and timing requirements for cold and hot pilot plant space. The meetings provided sufficient data to: (1) establish that most cold pilot plant space requirements can be met until FY-1995 in the existing facility. (2) determine that a new Technology Development Facility will be needed by FY-1995 to adequately support the technology development program, and (3) define hot cell space requirements for the MPPF.

A facility use plan for the CPP.637 pilot plant space was completed. The floor plan space layout for the new cold pilot plants was prepared; and 
demolition, construction, and timing requirements for new installations were defined. Work to engineer changes required to modify the existing pilot plant space to meet the requirements of the development program was performed.

An evaluation of the feasibility of adapting CPP-601 first cycle equipment for treatment of SBW solutions was completed. It appears that: use of equipment in E, F, G, and H-cells is possible; (2) solutions can be transferred back from the tank farm to G-cell via the first cycle raffinate line, and (3) with a minor modification, six E-cell and three G-cell vessels could be filled with feed.

To meet the development space needs of the Applied Technology department for hot testing facilities in the near future the CPP.627 facility was evaluated, and several possible uses were identified. The Operations department is scheduled to complete clean up of contamination from the Custom Process accident by the end of the fiscal year, and will then transfer their portion of the facility to Applied Technology.

A Space Evaluations Coordination meeting was held with the SBW group to determine the space requirements and schedule for testing and development. The new schedule and testing plans are being revised to comply with the DOE/Navy/State of Idaho Agreement to accelerate the technology development for SBW. A tentative test plan and schedule were developed, and existing facilities are being reviewed to make sure space can be provided.

\section{Hot Cells/Other Facilities}

An investigation into the possibilities of using ANL-West facilities for development space identified that ANL-West has hot cell space available for WINCO use. The space is in the argon shielded Hot Fuel Examination Facility (HFEF) North Cell and in an air atmosphere Decontamination Cell adjacent to the HFEF North Ce11. The ANL-West facilities have several non-destructive and destructive testing capabilities that can support the development program.

A coordination meeting was held with the ANL-West hot cell operations personnel and WINCO. The meeting identified at least three development program tests that can be carried out in the ANL-West hot cell space. The 
ANL-West hot cell space has 1 iquid waste handling constraints that will hinder their usage for all the development hot cell space requirements.

A technical exchange meeting was held to define the facility size, utilities, and environmental conditions of the development work being proposed for the ANL-West cell space. The meeting identified the requirements to fit graphite fuels, decontamination development, some calcine immobilization, and SBW processing development work into the HFEF North Cell. The meeting identified: (1; areas that need further investigation by ANL-West; (2) actions items to identify the best fit applications for the ANL-West hot cel1; (3) what environmental permitting will be required to work at ANL-West; and (4) the need to investigate the use of the ANL-West Sodium Treatment Facility for possible Applied Technology Development space needs.

ANL-West notified WINCO that their HFEF North Cell can be utilized by the Applied Technology development program as soon as November 1993. Technical exchange meetings are underway to determine environmental permitting, work scope, and other requirements to prepare the HFEF for the receipt of the development experiments.

ANL-West engineers toured the CPP.637 Pilot Plant Development area to view the calcine and decontaminaticn pilot plants. Information from this visit will be used to formulate plans for installing similar devices in the ANL-West HFEF North Cel1. WINCO engineers provided additional insight and information relating to the Calcine Immobilization Program and the Decontamination Development Program. The visit supplemented the preliminary schedules, and program plans were transferred to ANL-West. The schedules and plans have also be sent to WINCO's environmental organization, Operational Safety Analysis group and Operations department to allow their efforts to begin to support performing the hot cell work in the HFEF.

The TAN hot cells were evaluated for possible use for development space for the program. The TAN hot cell's limited waste handling capabilities, and their safety analysis documents and maintenance have not been kept current. The facilities will be evaluated further to try and fit processes to the facilities within the limits of the safety analysis reports, and with minimal upgrading of the facilities to supply usable space. 
A proposal for reuse existing calcine to calcine the SBW was presented to department management. This proposal involves redissolving CSSF Bin Set 1.3 calcine, blending it with SBW, and recalcining this blend. The resulting calcine would represent a $12 \%$ increase in the mass over dissolved calcine and would eliminate the need for processing with cold ANN.

The FPR surplus listings were reviewed for materials and equipment that could be utilized in the construction of the MPPF and other department development facility modifications. Some of the excess process vessels from FPR will be stored at FPR for future development work.

Efforts are underway to identify hot cell space to support Calcine Immobilization development activities. The Multi-Curie Cell and adjoining areas were identified as the most suitable area to support program schedules and space requirements. Although the Multi-Curie Cell is the primary area under consideration, additional cell space will be required to support program objectives. Portable hot cells are being evaluated to meet the extra space demand. Petersen Special Fabrication of Ogden, Utah was visited April 30. 1993 to discuss WINCO portable hot cell needs and inspect cells they have fabricated for Westinghouse Hanford. Attempts are being made to identify additional portable or hot cell users that can provide further input.

\section{Environmental Permits/Air Emission Study}

Data input for the site wide environmental impact statement (EIS) and EA relating to the MPPF and the Waste Immobilization Facility (WIF) were compiled for inclusion in these documents.

The preliminary air emission data for the MPPF, WIF, and TDF were submitted to support the Environmental Restoration and Waste Management EIS.

The Site Wide EIS group requested that air emission data be submitted by March 12, 1993. Facilities Support was able to supply the data for the EIS on the requested date. Supplying the data for the EIS has also satisfied a program milestone. 
WINCO determined that a National Emission Standards for Hazardous Air Pollutants (NESHAPS) permit application will not have to be completed for the MPPF. The estimated radionuclide emissions are below the recordable limits for NESHAPS. Another evaluation will be required for determination of permitting required for the proposed Production Development Facility (PDF) when more data is available to estimate the radionuclide emissions.

\section{Feasibility Studies}

The Functional and Operational Requirements document for the MPPF was completed. Development of design criteria will be an on-going effort, and will not be completed until the Title II design effort is started.

United Engineers and Contractors (UE\&C) started the phase II feasibility study for the "New MPPF" and completed the Justification for Mission Need in preparation to support Key Decision Point Zero. Meetings were held with UE\&C. and the MPPF building layout was completed for the phase II feasibility study. Several hot cell and cold pilot plant layout plans were evaluated.

EG\&G Idaho prepared a Task Based Agreement to perform the "FPR Conversion to MPPF" feasibility study, and started the feasibility study work. The FDP was identified as the preferred candidate for fuel canning. This project will be responsible for the FDP documentation, and will be coordinated with Applied Technologies need for spent fuel hot cell requirements. The feasibility study is the first step in determining the FPR future. A preliminary building layout was completed and the outline of the study report was finalized.

Several working sessions and conference calls with UE\&C identified a number of potential cost reductions to maintain the "New MPPF" cost within Facility and Operational Requirements (F\&OR) cost projections. These reductions include eliminating cranes inside the hot cells, reducing the number of viewing windows, fabricating the in-cell PAR bridge out of carbon steel, requiring scrubbers on pilot plant modules, and lowering the stainless steel liner on walls inside the cell to four feet. In addition to the cost savings above, the cold pilot plant may be relocated above the hot cells to minimize floor space and to eliminate the cold pilot plant high bay crane. 
The EG\&G Idaho feasibility study has identified four cells (\#1, \#3, \#6 and \#8) in FPR to be used as hot cells. The operating corridor for those cells were identified as the west end storage rooms (west side of Cell \#1). Cel1 \#2, Cell \#5, and Cell \#7. The maintenance area (high bay) was selected as the cold pilot plant area. Three-dimensional models of the cells were developed for better visual viewing of equipment locations.

Meetings were held with UE\&C and the optimum MPPF building layout for cost and space utilization was approved. The conceptual design criteria for the MPPF was placed on hold by DOE.

The EG\&G Idaho cost estimate for the feasibility study to use FPR as the building for the MPPF was completed. The feasibility report draft was transmitted to WINCO for review and comment.

The draft feasibility study for the MPPF in the FPR building was issued, reviewed, and the comments resolved and transmitted to EG\&G Idaho. The scope of work for UE\&C is being rewritten to include the phased entry in FPR and PDF approach.

The feasibility study for using the FPR as the structure for the MPPF was completed, and the final report was issued by EG\&G Idaho. The study found that the FPR can provide the development space needed for the MPPF, but the FPR structure is two and a half times the size required for a new MPPF. The extra space, and bringing the structure up to an occupiable condition, will result in a greater expense than a new facility, but using the FPR structure is more cost effective per square foot than a new facility.

The feasibility study for a new MPPF was completed by United Engineers, and final review comments were incorporated. The study found that providing four hot cell spaces and a large cold pilot plant area for integrated testing would cost approximately $\$ 115$ million dollars.

The approval for conceptual design work on the MPPF has not been confirmed or canceled. DOE-ID has given WINCO verbal direction to put the MPPF conceptual design on hold. The funding for FY.94 was zeroed out for the 
MPPF, so WINCO is assuming the approval to proceed with the MPPF conceptual design will not be given. The next effort that WINCO is proposing is to study the feasibility of a phased entry into FPR, and a new facility to support the different development efforts as they are funded. This new effort will also be evaluating the requirements for supplying a production demonstration facility in-lieu of a pilot plant facility. The emphasis for providing development space is to optimize existing facilities first, then construct only the facilities needed after using existing capabilities.

The scope of work for feasibility studies to use part of FPR or construct part or parts of the MPPF providing space as required was prepared. This next phase of studies will investigate the sizing and costs of a PDF for the final process proposed for conditioning wastes and fuels for disposal in a geologic repository. The efforts to provide development space will continue to emphasize the optimization of existing facilities.

The first facility space layout for the PDF feasibility study was completed. The PDF flowsheets were finalized using the MPPF flowsheets from earlier studies. Preliminary results from the MPPF study of phasing the effort into FPR or into a new facility show the phased approach is more expensive than construction of the facility at one time. The preliminary studies also show that using an existing facility for the MPPF will be more expensive.

Raytheon Engineering of Denver (Raytheon) completed a feasibility studies contract to: (1) provide a production scale development demonstration facility that can be converted to hot operations, and (2) evaluate phased construction of the MPPF. The production scale study was used for a basis short form data sheet submittal requesting a 1997 line item project.

On-Site Storage LLW/LLW Facility information on the LLW Grouting and Storage Facilities at the West Valley Demonstration Project was received and copies of the information were forwarded to Raytheon. The possibility of implementing a "Saving Through Sharing" project by utilizing the LLW processing technology at West Valley is being considered. 
The feasibility study for providing surrogate cold calcine for near-full scale glass-ceramic testing was completed and found that the calcine could best be supplied from an outside source.

\section{Technology Development Facility}

The completed Facility Requirements Evaluation was transmitted to DOE and used to determine the needs for the Technology Development Facility (TDF).

Using information from the Facility Requirements Evaluation the programs for TDF were identified (mid-sized calcine immobilization pilot plant and a laser decontamination module). Flowsheets were prepared for these processes. These flowsheets are being used in to prepare an environmental checklist and for the CX/EA/PTC efforts.

The TDF was approved by WINCO as a FY.94 project. The TDF F\&OR document was written, reviewed and comments incorporated. A space utilization study is underway to provide cold pilot plant work for the TDF to minimize environmental permitting requirements and expedite construction.

The environmental checklist for the TDF was issued to DOE. The determination was made that PSD permits would be required for some of the pilot plants that will go into the TDF, and document preparation was initiated. Research and calculations for the air permitting were included in a draft report.

The TDF general plant project is being accelerated to provide space to support the DOE/Navy/State of Idaho agreement dates. The design will begin soon to expedite construction in 1994. A Idaho Air Quality Permitting Applicability Questionnaire was drafted and forwarded to the Environmental Group. Investigation of the off-gas from the mid-scale Calcine Immobilization Pilot Plant (CIPP) revealed that oxides of sulfur $\left(\mathrm{SO}_{\mathrm{x}}\right)$ emissions will require a $\mathrm{SO}_{\mathrm{x}}$ scrubber. This study has concluded that stainless steel calcine may be excluded from the CIPP as a test material feed. The TDF is expected to receive a $C X$ for environmental permitting that will not require inclusion as part of the EIS. 


\section{Inventions}

The Vortex Diode (Vordi) Jet invented by one of the members in the Facility Support Section was flagged for technology transfer and referred to the Privatization Committee. A patent application for the vordi jet was filed May 27. 1993. The vordi jet was selected as one of twenty three corporate finalists for the George Westinghouse Signature Award of Excellence.

A Fluidic Sampler patent application was filed with the Patent Office in early August. The fluidic sampler permits the unbiased sampling of pressurized sample streams. This ability comes from the inherent nature of the fluidic sampler. Fluids flow into the process line except when a sample bottle is in place. Removal of the sample bottle only permits a small stream of air to be injected into the process stream through the sample needle. This characteristic of the fluidic sampler allows the safe use of fluidic and mechanical pumps in radioactive and hazardous solution sample systems. 


\section{REFERENCES}

1. I. N. Christiansen, Updated Spent Fuel and Waste Management Technology Development Program Plan. WINCO-1176, September 1993.

2. R. Shikashio, Performance Assessment Appendix A: Spent Fuel and Waste Information. WINCO-1148, January 1993.

3. K. E. Archibald, $\mathrm{CO}_{2}$ Pellet Blasting Literature Search and Decontamination Scoping Tests Report. WINCO-1180, January 1994.

4. R. L. Demmer. Development of Simulated Contamination (SIMCON) and Miscellaneous Scoping Tests. WINCO-1188, January 1994.

5. R. L. Ferguson, Liquid Abrasive Grit Blasting Literature Search and Decontamination Scoping Tests Report. WINCO-1163, October 1993.

6. H. M. Pang, M. C. Edelson, R. L. Demmer, Metal Decontamination U/sing High Power Lasers, Conference Proceedings - ER '93. Augusta, Georgia, October 1993.

7. S. V. Raman, Hot Isostatically Pressed Aluminosilicate Glass-Ceramic with Natural Crystalline Analogues for Immobilizing the Calcined High Level Nuclear Waste at the Idaho Chemical Processing Plant. WINCO-1173,

8. K. Vinjamuri. Ialc-Silicon Glass-Ceramic Waste Forms For Immobilization of High-Level Calcined Waste, WINCO-1129.

9. L. L. Taylor, Preliminary Waste Acceptance Criteria for the ICPP Spent Euel and Waste Management Technology Development Program. WINCO-1157.

10. G. F. Kessinger, Decontamination of FAST (CPP-666) Fuel Storage Area Stainless Steel Fuel Storage Racks. WINCO-1164, October 1993.

11. G. F. Kessinger, Evaluation of the Electrorefining Technique for the Processing of Radioactive Scrap Metals, WINCO-1165, October 1993. 


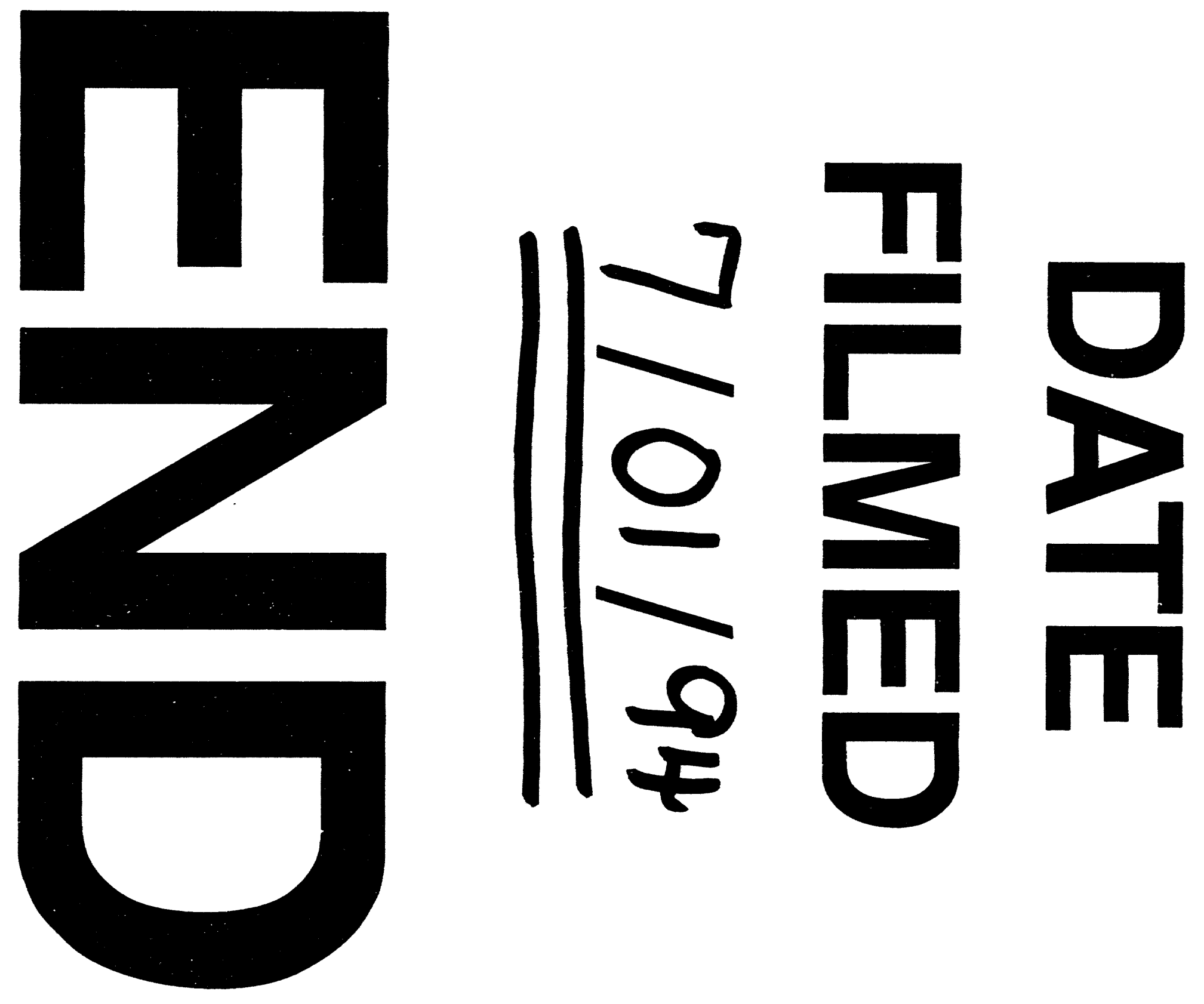


